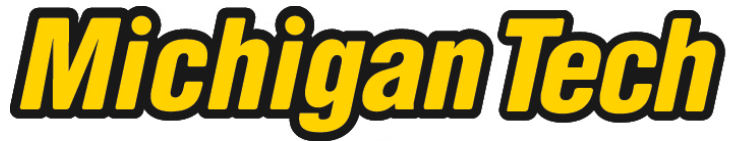 \\ Michigan Technological University Create the Future Digital Commons @ Michigan Tech
}

\section{UNDERSTANDING FARMERS' PERCEPTIONS AND THE EFFECTS OF SHEA TREE Vitellaria paradoxa DISTRIBUTION IN AGROFORESTRY PARKLANDS OF THE UPPER WEST REGION, GHANA}

Fahimeh Baziari

Michigan Technological University

Follow this and additional works at: https://digitalcommons.mtu.edu/etds

Part of the Agriculture Commons, Forest Sciences Commons, and the Natural Resources

Management and Policy Commons

Copyright 2015 Fahimeh Baziari

\section{Recommended Citation}

Baziari, Fahimeh, "UNDERSTANDING FARMERS' PERCEPTIONS AND THE EFFECTS OF SHEA TREE Vitellaria paradoxa DISTRIBUTION IN AGROFORESTRY PARKLANDS OF THE UPPER WEST REGION, GHANA", Master's Thesis, Michigan Technological University, 2015.

https://doi.org/10.37099/mtu.dc.etds/937

Follow this and additional works at: https://digitalcommons.mtu.edu/etds

Part of the Agriculture Commons, Forest Sciences Commons, and the Natural Resources Management and Policy Commons 
UNDERSTANDING FARMERS' PERCEPTIONS AND THE EFFECTS OF SHEA TREE Vitellarial paradoxa DISTRIBUTION IN AGROFORESTRY PARKLANDS OF UPPER WEST REGION, GHANA

By

Fahimeh Baziari

A THESIS

Submitted in partial fulfillment of the requirements for the degree of

MASTER OF SCIENCE

In Forestry

MICHIGAN TECHNOLOGICAL UNIVERSITY

2015

(C) 2015 Fahimeh Baziari 
This thesis has been approved in partial fulfillment of the requirements for the Degree of MASTER OF SCIENCE in Forestry.

School of Forest Resources and Environmental Science

Thesis Advisor: Dr. Molly Cavaleri

Committee member: Dr. Blair Orr

Committee member: Dr. Kari Henquinet

School Dean: Dr. Terry Sharik 


\section{TABLE OF CONTENTS}

LIST OF FIGURES ............................................................................................................ v

LIST OF TABLES …......................................................................................... vii

ACKNOWLEDGMENTS ........................................................................................... vii

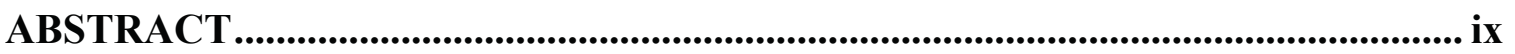

CHAPTER 1: GENERAL BACKGROUND.............................................................. 1

SECTION 1: BACKGROUND ..................................................................................... 4

CHAPTER 2: GHANA BACKGROUND ......................................................................... 5

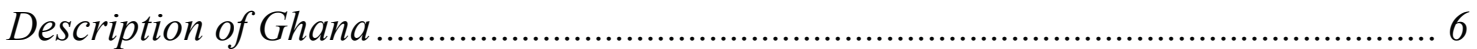

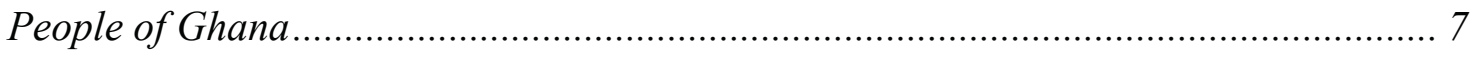

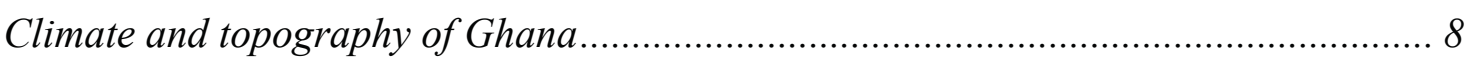

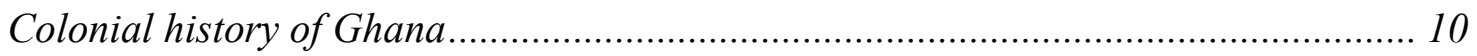

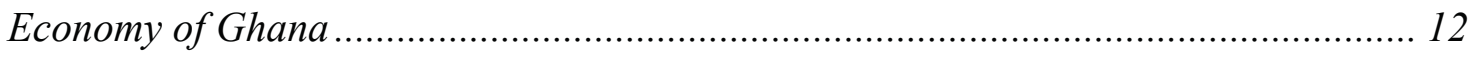

CHAPTER 3: STUDY AREA BACKGROUND …........................................................ 15

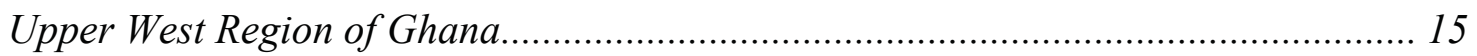

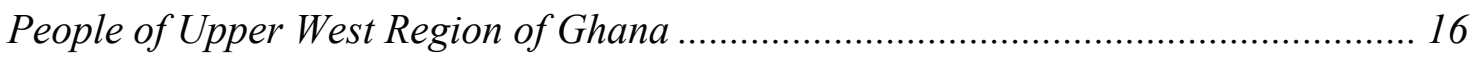

Climate and Topography of the Upper West Region of Ghana .................................. 18

Economy of Upper West Region of Ghana........................................................... 19

Agriculture reform and poverty of Upper West Region of Ghana ................................ 24

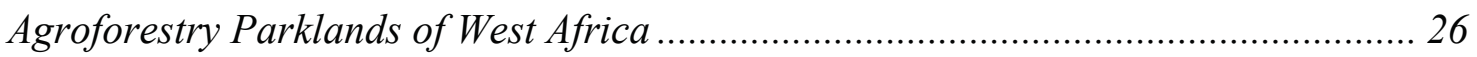

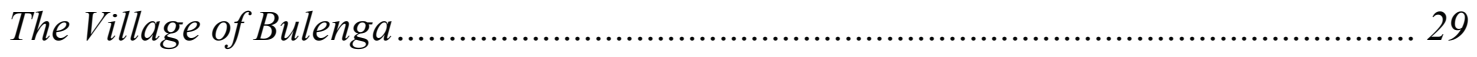

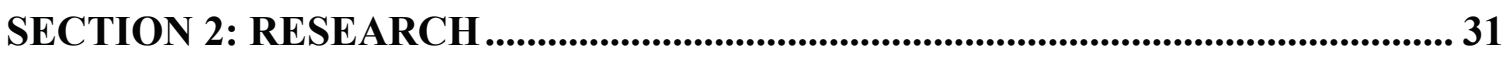

CHAPTER 4: INTRODUCTION TO RESEARCH.............................................. 32

CHAPTER 5: MATERIALS AND METHODS ...................................................... 36

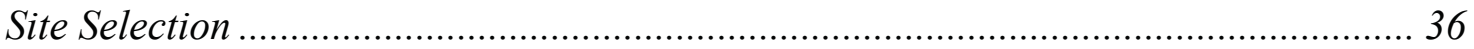

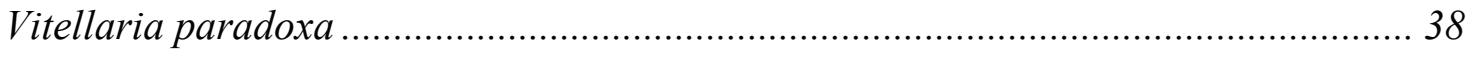

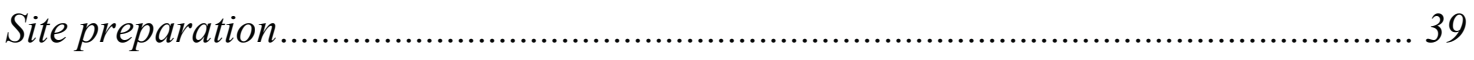

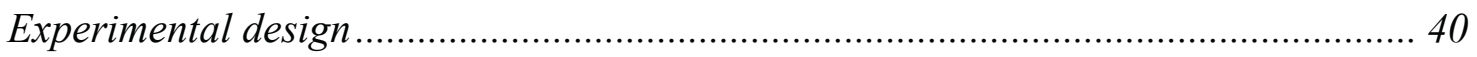

Soil moisture

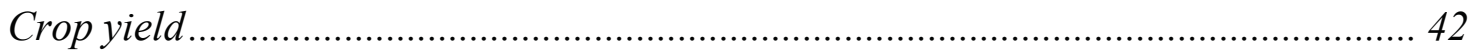

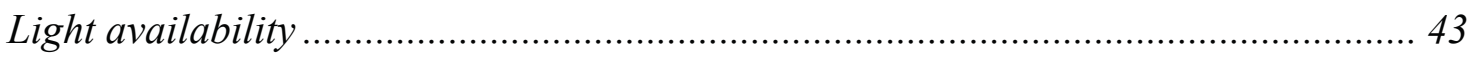




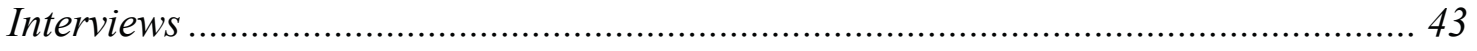

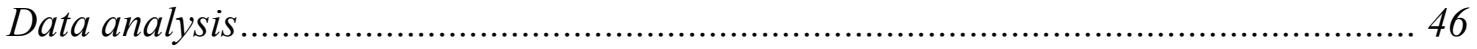

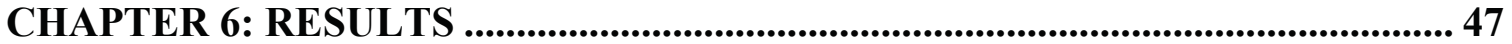

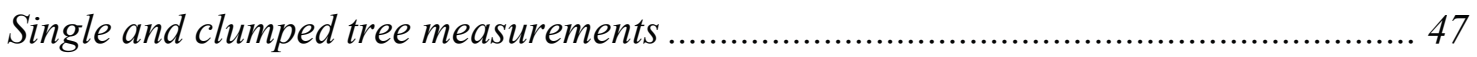

Effects of single and clumped trees on light availability and soil moisture................. 47

Effects of clumped vs. single trees on vegetative growth and yield of maize................ 48

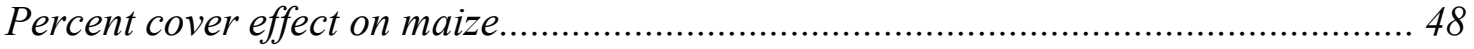

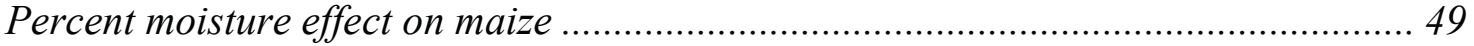

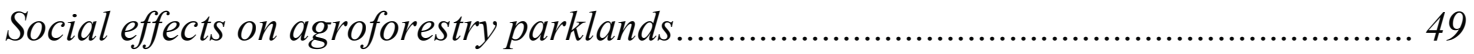

CHAPTER 7: DISCUSSION ............................................................................ 57

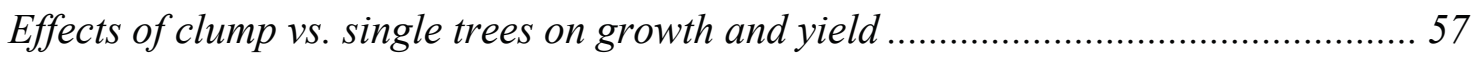

Effects of light and soil moisture on growth and yield.......................................... 59

Decision making with respect to maintenance and spacing of agroforestry parklands 61

CHAPTER 8: CONCLUSIONS AND CONSIDERATIONS ................................. 66

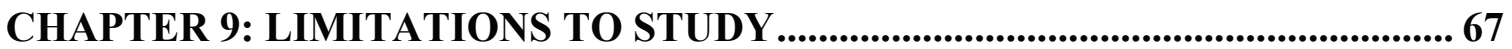

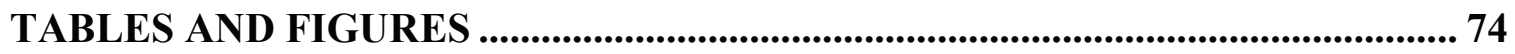

APPENDIX A

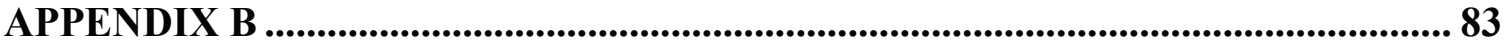

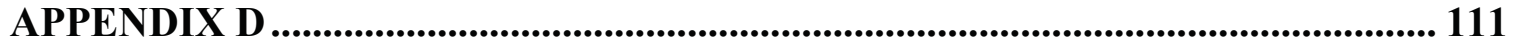




\section{LIST OF FIGURES}

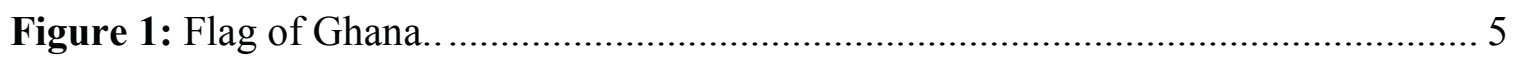

Figure 2: Ghana's location in Africa and the 10 Regions of Ghana ............................... 6

Figure 3: Nsawam Road, modern Accra................................................................ 7

Figure 4: (A) Bride and groom at their traditional wedding. (B) Same bride and groom at

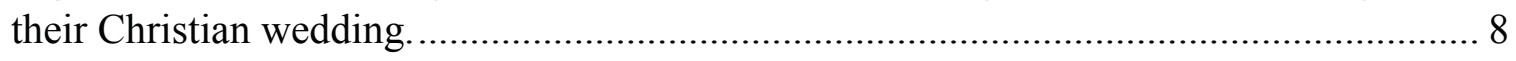

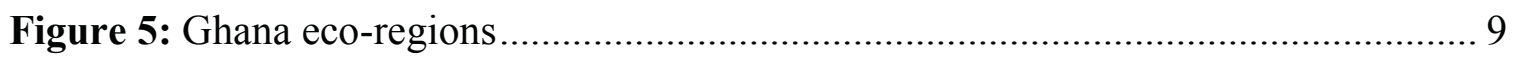

Figure 6: Fishermen and bathers in the Volta River delta. ...................................... 10

Figure 7: Typical cocoa farm located in the Eastern Region...................................... 13

Figure 8: Wa East district located in the Upper West Region of Ghana ....................... 15

Figure 9: Women in a family packing down a mud roof......................................... 16

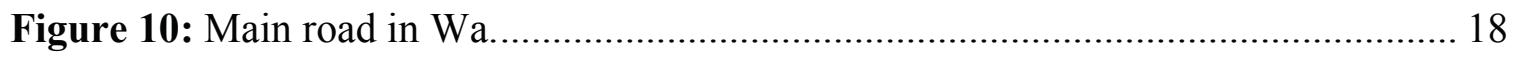

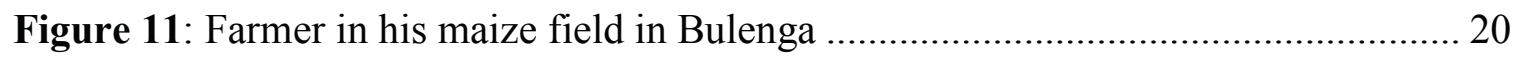

Figure 12: Loading cattle to be transported for sale. ............................................ 21

Figure 13: (A) Local carpenter in Bulenga. (B) Local women of Bulenga selling soup for added income. (C) Beginning process of Kepe production. (D) Women rolling Kepe into balls. (E) Brewed pito waiting to be sold. (F) Men at market day enjoying pito together at

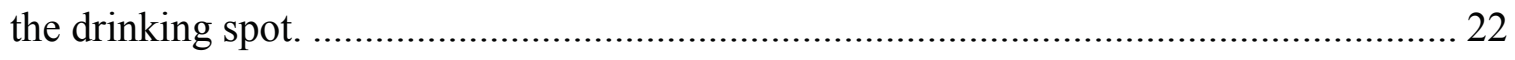

Figure 14: Illegal gold miner separating the gold filled silt from sand......................... 23

Figure 15: A common form of maize threshing.................................................... 24

Figure 16: Farmer posing next to his tractor that he acquired through an aid program... 26

Figure 17 (A) Cut V. paradoxa branches to make hand hoes. (B) Burning shea tree stump

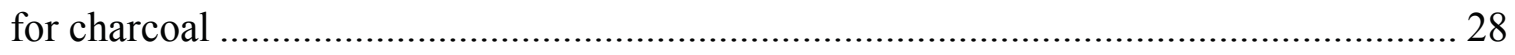

Figure 18: (A) Dried shea nuts are parboiled in preparation for making shea butter. (B) Women working together to prepare shea butter................................................. 28

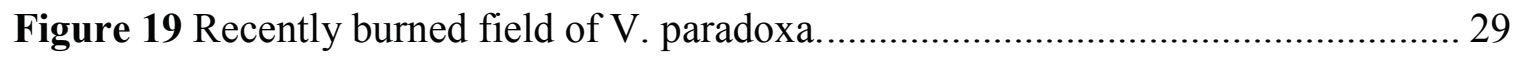


Figure 20: (A) Celebration of Eid el-Adha in Bulenga. (B) Market day in Bulenga. ..... 30

Figure 21: (A) Example of single tree on farm. (B) Example of clump tree on farm..... 37

Figure 22: (A) Pruned V. paradoxa showing red blaze and latex secretions. (B) Leaves and fruit of $\mathrm{V}$. paradoxa. .

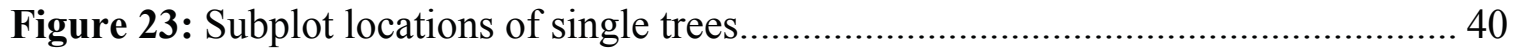

Figure 24: Example of triangles formed within clumped trees and associated maize sampling plots.

Figure 25: (A) $20 \mathrm{~cm}$ soil sample (B) Soil sample drying while collecting..... 42

Figure 26: (A) Mean percent cover of each measurement location of single and clumped trees. (B) \% moisture of each measurement location of single and clumped trees. 76

Figure 27: Vegetative and yield effects on maize crops associated with single and clumped trees.

Figure 28: Correlations between percent canopy cover......................................... 78

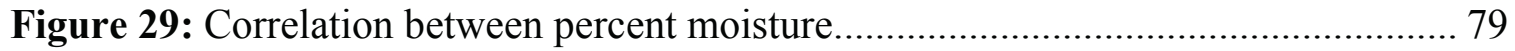

Figure 30: Women's farming constraints as perceived by women and men.................. 80

Figure 31: Crops grown by number of acres of farmers. Crops within other include: cassava, sorghum, watermelon, tomato, and bambara beans. 


\section{LIST OF TABLES}

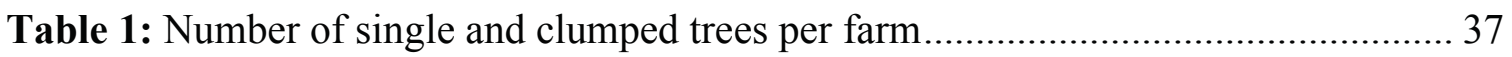

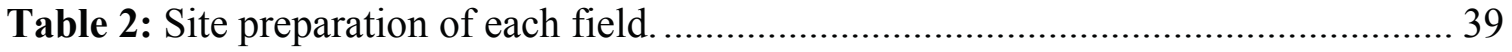

Table 3: Total of males and females interviewed by age range ................................. 43

Table 4: Dbh, height, and crown diameter of single and clumped trees ....................... 75

Table 5: Number of subplots per location of single trees and clumped trees ................ 82 


\section{ACKNOWLEDGMENTS}

I would like to thank my parents Ali Baziari and Debra McLaughlin who have been a great support. I would like to thank my siblings Fereshteh Chapman and my brother-in-law Andy Chapman who have always been able to answer a phone call when I needed to talk, and Farideh Golembiewski and my brother-in-law Michael Golembewski who always remind me to take it easy and laugh.

I would like to thank my friends, Kailie Asam, Lindsay Garfield, Maura Hannan, and Vanessa Marklink who have sent packages that remind me I wasn't forgotten back home. I would like to thank Mr. and Mrs. Asam as well as Mr. and Mrs. Chapman who have supported many of my projects while I was in Ghana. I would also like to thank my boyfriend $\mathrm{KJ}$ for his unconditional patience.

I would like to thank my academic advisor Molly Cavaleri for her commitment and dedication. Thank you for pushing me as a student, and helping me to reach my goals. I would like to thank Jean-Marc Boffa for his guidance and his enthusiasm for agroforestry parklands. Thank you to my academic advisors Kari Henquinet who assisted me in the thesis writing process, and Blair Orr whose knowledge and experience of the developing world helped me make it through Africa.

I would like to thank Abdul-Rahaman Daa for being such an understanding friend. I would also like to thank Mashood Dori, who was a second father to me while in Ghana.

I would like to thank my Peace Corps friends for great memories. Lastly, I would also like to thank Justin Gelb for being such a great PCMI. 


\begin{abstract}
Agroforestry parklands represent a vast majority of the agricultural landscape under subsistent-oriented farming in semi-arid West Africa. Parklands are characterized by the growth of well- maintained trees (e.g., shea) on cultivated fields as a result of both environmental and human influences. Shea (Vitellaria paradoxa) provides a cultural and economic benefit to the local people of Ghana, especially women. Periods between traditional fallow rotation systems have reduced recently due to agricultural development and a demand for higher production. As a result, shea trees, which regenerate during fallow periods, has decreased over the landscape. The aim of this study was to determine beneficial spatial distributions of $V$. paradoxa to maintain high yields of staple crops, and how management of $\mathrm{V}$. paradoxa will differ between male and female farmers as a result of farmer based needs and use of shea. Vegetation growth and grain yield of maize (Zea mays) associated with individual trees, clumped trees, and open fields were measured. Soil moisture and light availability were also measured to determine how $V$. paradoxa affected resource availability of maize in either clumped or scattered distributions of $\mathrm{V}$. paradoxa. As expected, light availability increased as measurement locations moved farther away from all trees. However, soil moisture was actually greater under trees in clumps than under individual trees. Maize stalk height and cob length showed no difference between clumped and single trees at each measurement location. Grain yield per plot and per cob increased as measurement locations moved farther from single trees, but was actually greater near clumped trees that in the open field subplots. Cob length and maize stalk height increased with greater light availability, but grain yield per cob or per plot showed no relationship with light, but were not affected by soil moisture.
\end{abstract}


Conversely, grain yield increased with increasing soil moisture, but had no relationship with light availability. Initial farming capital is the largest constraint to female farmers; therefore the collection of shea can help provide women with added income that could meet their specific farming needs. Our data indicate that overall effects of maintaining clumped distributions of $V$. paradoxa provided beneficial microclimates for staple crops when compared to single trees. It is recommended that male and female farmers allow shea to grow in clumped spatial distributions rather than maintaining scattered, individual trees. 


\section{CHAPTER 1: GENERAL BACKGROUND}

As a Peace Corps Volunteer, I was placed in the Upper West Region of Ghana. My assignment was to support a United States Agency for International Development (USAID) funded project under the Feed the Future Initiative. The project focused on increasing agricultural investment in the crop value chain in Ghana by linking smallholder farmers to markets, finance, inputs and equipment services to adopt a business oriented farming strategy. This projected allowed farmers to implement time saving mechanization such as plows and threshers, as well as chemical inputs to improve soil fertility and weed reduction that is relatively new to farming in the Upper West Region.

Recently, farmers have adopted a commercialized approach to farming. Transitioning farming systems can create environmental obstacles that farmers are difficult for farmers to overcome. Traditional bush-fallow systems that have been successfully used over in the past is not coinciding with new developed farming practices. My strategy was to identify areas in which developing agricultural practices could interrelate with traditional systems. So, I decided to start at the most basic level, the farm.

One major complaint that farmers had was that farm yields were low and fertilizer prices were too high. They needed an option to increase income, increase yields or improve soil fertility at a low cost. During conversations with farmers while working on their farms, I learned that many farmers believed that trees reduce crop growth, therefore they reduce the number of trees on their farm. Although, trees that provide an economic 
benefit are able to remain. Shea trees are often left on the farm because women can sell shea butter from collected nuts. However, shea is not easily regenerated due to improved commercialized farming practices and they are slowly disappearing from the landscape.

My objective was clear, shea provides many benefits such as an opportunity for added income as well as benefits to the farm; therefore I wanted to determine how shea trees should be managed on the farm while still maintaining high yields of crops. Although I had much to learn, first I needed to understand why farmers chose their particular farming strategies. After all, farming was a way of life in Bulenga, so farmers had an innate understanding about farming and made farming decisions based on years of inherited knowledge. Many of these practices were based on culture; therefore understanding how people thought about the land, and how they are tied to the land was important. Also, social structures had a large influence on who made on-farm decisions which is largely be based on gender. Therefore, in order to make an informed decision about best farming practices there are many different perspectives that needed to be taken into consideration.

Through the work that I carried out in Ghana showed that maize production is more limited by water availability than light availability, and also that maintaining trees in a clumped distribution was better for maize production than scattered distributions of individual trees in agroforestry parklands of Ghana. Women, who are often marginalized, can greatly benefit through the added income that collecting shea can provide as initial capital to farming.

Chapter 2 provides a summarized background of Ghana, and the differences that northern and southern Ghana face. Bulenga, located in the Upper West Region and where 
this study took place, is discussed in Chapter 3. This chapter goes into detail about farming practices of agroforestry parklands in Bulenga.

Chapter 4 provides a more detailed description of the importance of shea in agroforestry parklands, threats that affect regeneration, and why shea is significant to the livelihood of the local people. The methodology that was used in this study is listed in Chapter 5. This section discusses the shea species, experimental design, and farmer interviews and data analysis.

Chapter 6 lists the effects that environmental variables had on the productivity of maize, and how stem density of shea affected crop growth and yield. Chapter 7 includes the discussion of results. In this section I examine how my results either support or reject my hypothesis and speculate why or why not. Chapter 8 includes conclusions and implications. This section provides management suggestions that farmers could adopt based on what I found in this study. 
SECTION 1: BACKGROUND 


\section{CHAPTER 2: GHANA BACKGROUND}

In 1957, Ghana was the first Sub-Saharan country to gain its independence from colonial rule (CIA, 2012). The fight for independence and the spirit of the people are best described through the symbolism of the Ghanaian flag (Figure 1). The Ghanaian flag is separated in to three horizontal stripes with a black five-pointed star in the middle. The top color is red which is used to represent the blood shed for independence, and their struggle throughout history in their fight for freedom. The middle color is yellow which represents the mineral wealth that is found in Ghana's gold coast. The last color is green which represents the country's rich natural resources (CIA, 2012). Lastly, the black star represents the freedom of the people. The black star was adopted from the Black Star Line founded by the Jamaican political leader and activist, Marcus Mosiah Garvey, Jr. The Black Star Line was transportation system that stimulated the diaspora of natives to return to their ancestral homelands (Shepperson, 1960).

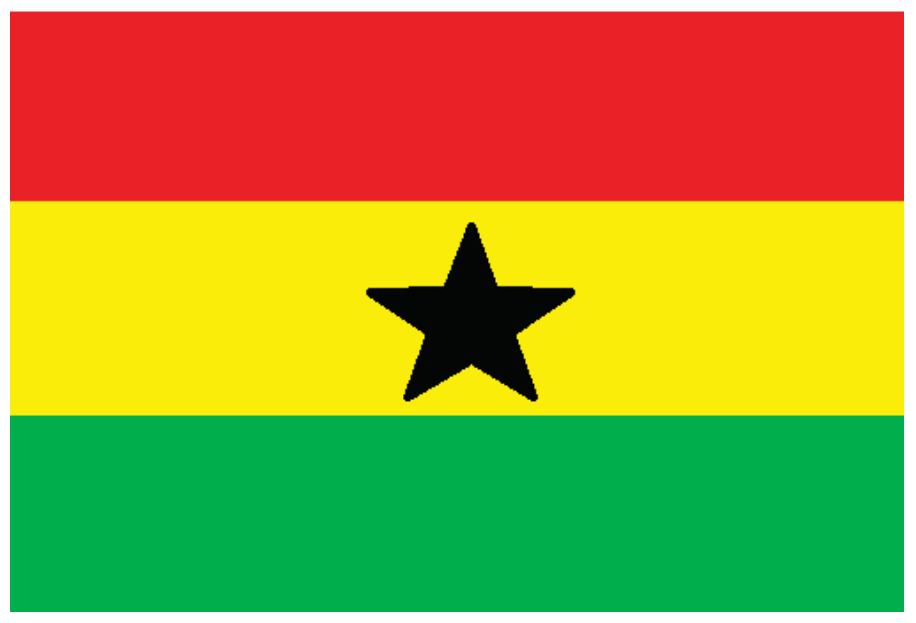

Figure 1: Flag of Ghana. Drawn by Fahimeh Baziari. 


\section{Description of Ghana}

Ghana, formerly known as the Gold Coast, is located in West Africa along the Gulf of Guinea in the Atlantic Ocean. Ghana has a land mass area of 238,533 sq. km which is slightly smaller than the size of Oregon (CIA, 2012). Ghana borders Togo to the east, Cote d'Ivoire to the west, and Burkina Faso to the north. Ghana is separated into ten different regions: Greater Accra, Western, Central, Eastern, Volta, Ashanti, Brong Ahafo, Northern, Upper East, and Upper West (Figure 2). Accra is the capital city located in the Greater Accra Region (Figure 3).

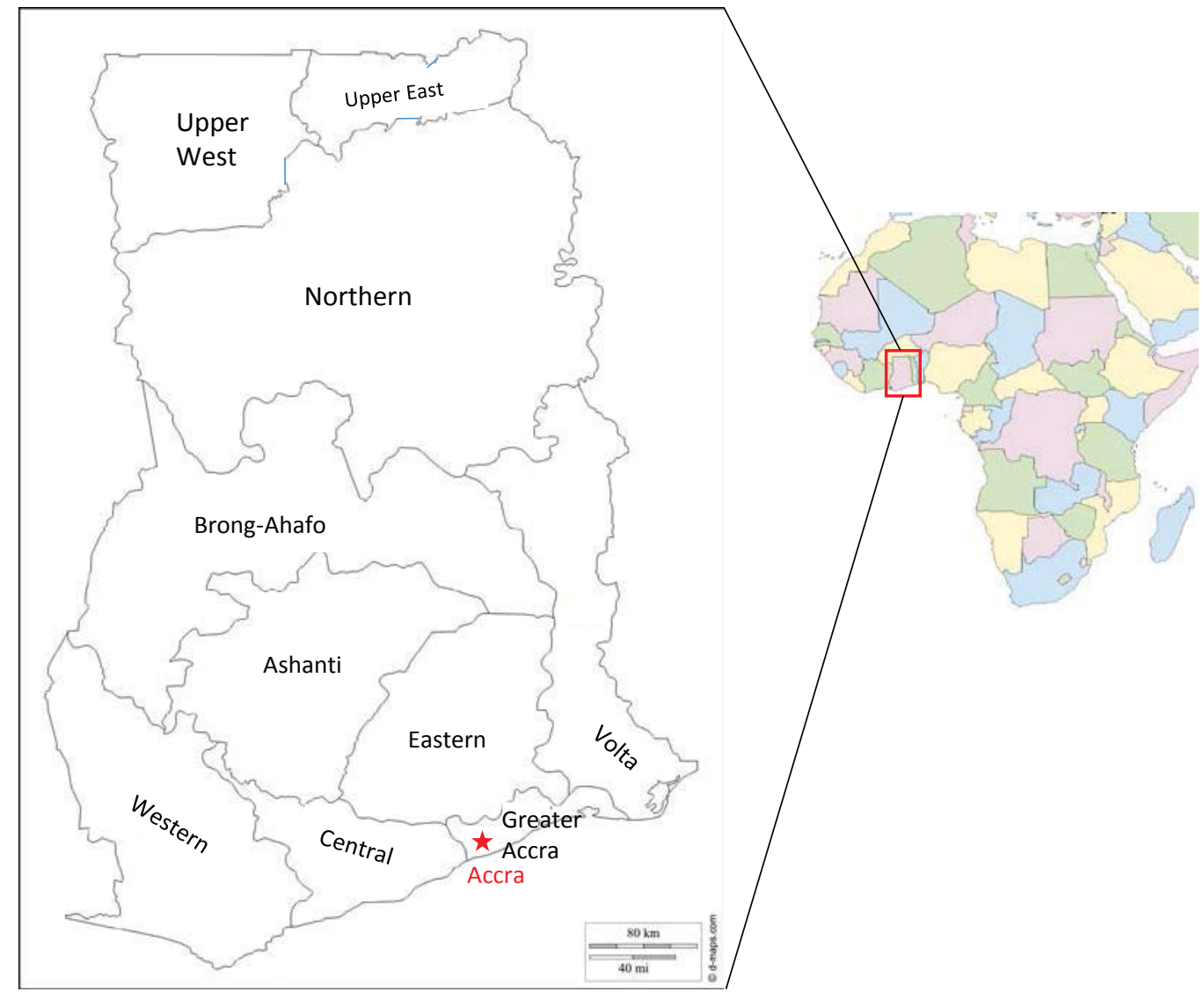

Figure 2: Ghana's location in Africa and the 10 Regions of Ghana Source: D-maps.com 


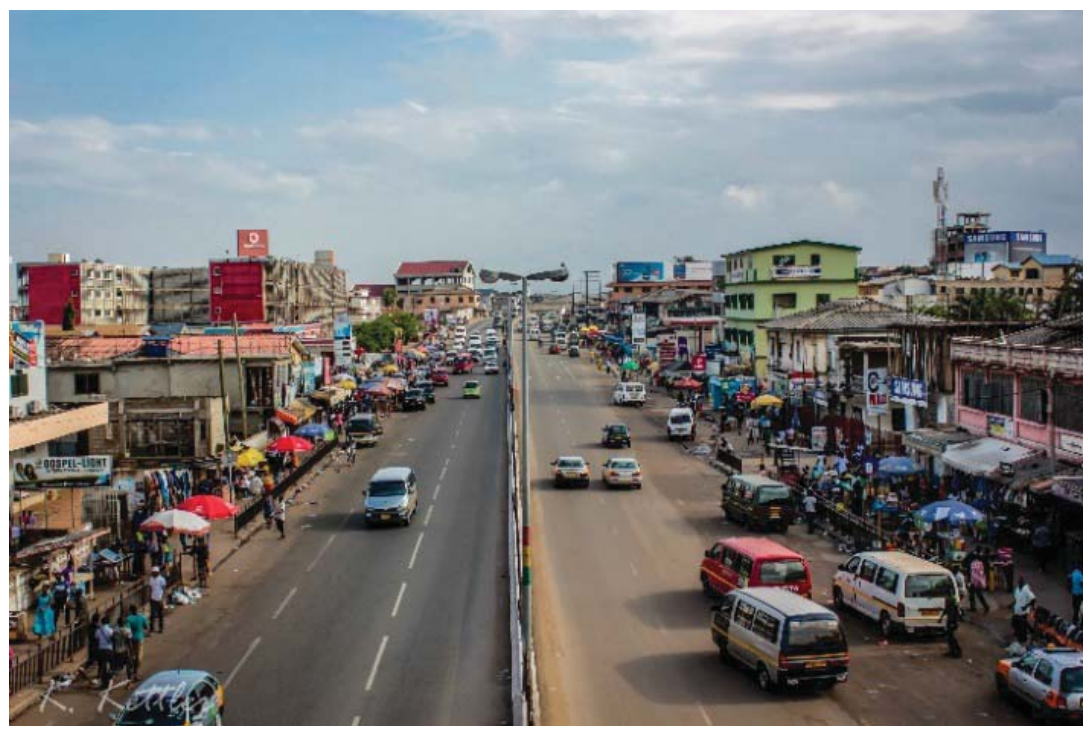

Figure 3 Nsawam Road, modern Accra, Ghana. Photo by Kenneth Kettler

\section{People of Ghana}

Ghana is the $82^{\text {nd }}$ most populous country in the world with a population of $25,758,108$ people. There are eight major ethnic groups in Ghana. The three largest ethnic groups are Akan, Mole-Dagbon, and Ewe. These ethnic groups make up 41\% of the population (CIA, 2012). Akan are concentrated mainly in the south and coast, MoleDagbon in the north and Ewe along the Togo boarder. The largest religious influences in Ghana are Christianity, Islam and traditional religion. Christianity is concentrated in the south as Christian missionaries entered Ghana from the coast (Fage, 1966). Islamic presence is predominantly found in the Northern regions of Ghana as North Africa developed trade routes and intellectual development within West Africa (Hill, 2009). Traditional beliefs are still practiced throughout Ghana, often blended with either Christianity or Islam beliefs (Figure 4A, 4B). 

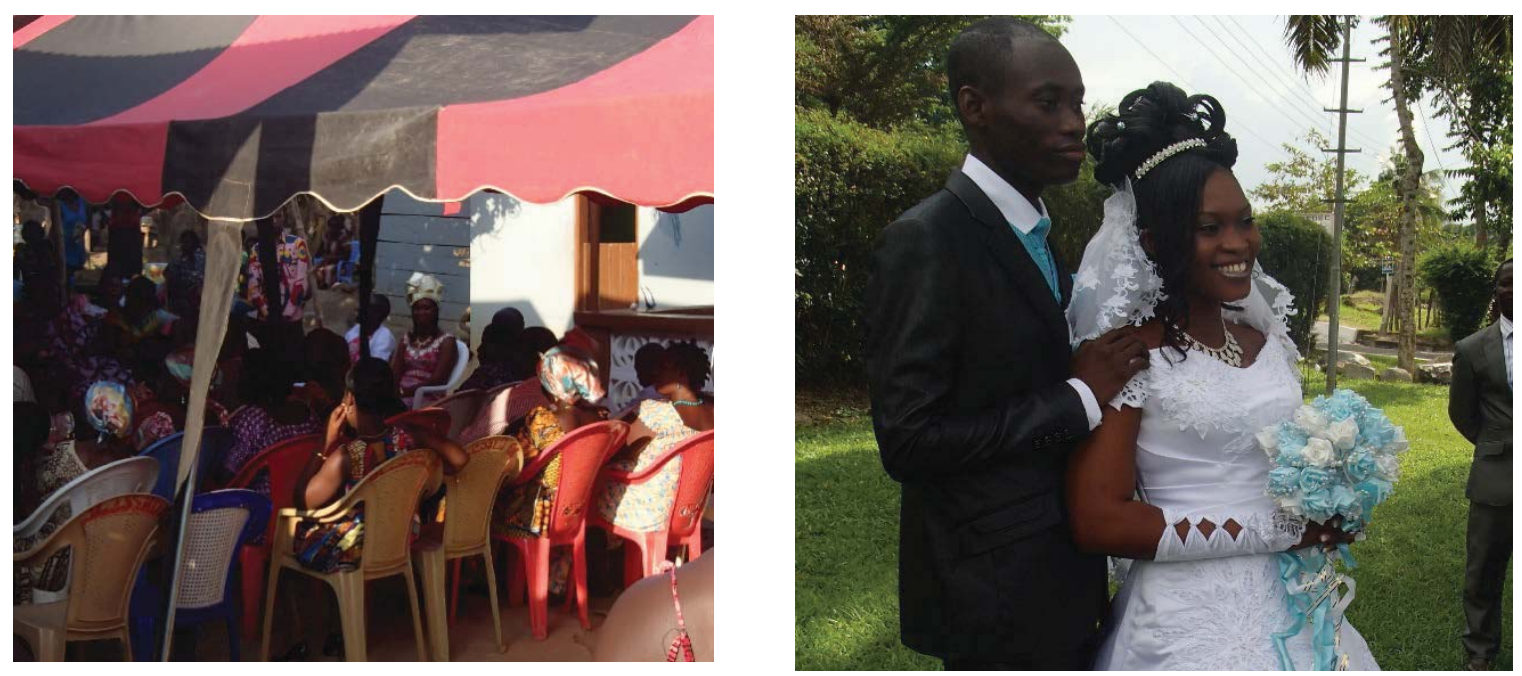

Figure 4: (A) Bride and groom at their traditional wedding. (B) Same bride and groom at their Christian wedding. All photos by Fahimeh Baziari, unless otherwise stated.

\section{Climate and topography of Ghana}

Ghana's topography is primarily one of low relief with undulating flats that have grades of less than $1 \%$, with dissected plains located in the northwestern part of Ghana. Ghana's highest point is Mount Afadjato located in the Akwapim-Togo ranges which reaches an elevation of $880 \mathrm{~m}$ above sea level (CIA, 2012). The Volta basin is located in the central part of Ghana. The three main tributaries of the Volta River Basin include the Black Volta, Red Volta and the White Volta rivers which enter into Lake Volta before reaching the Atlantic Ocean. Lake Volta was dammed in 1965 by the Akosombo Dam, and is the largest man made reservoir in the world by surface area $(8,482$ sq. $\mathrm{km} ; 3,275$ sq. mi) (CIA, 2012).

Ghana is geographically located in the tropical zone about 400 miles north of the Equator. Ghana can be separated into six eco-regions: coastal savannah, deciduous forest, transitional zone, guinea savannah, Sudan savannah, moist evergreen, and wet evergreen. Hot and humid climates are found in the southwest, while warm and dry climates are 
found in the southeast (Figure 5). The northern climates, in the Guinea Savannah, are characterized as hot and dry (CIA, 2012). The hot dry temperatures and the hot and humid temperatures are delineated at the $9^{\text {th }}$ parallel that runs through the transition zone.

The Northern eco-regions experience unimodal rainfall patterns, characterized as having one wet season. In transitional zone, forest and coastal regions experience a bimodal rainfall pattern with two rainy seasons, major and minor (FAO, 2005). The dry season in the north begins in November with the onset of a dry, dusty northeasterly wind originating from the Saharan desert commonly known in West Africa as Harmattan.

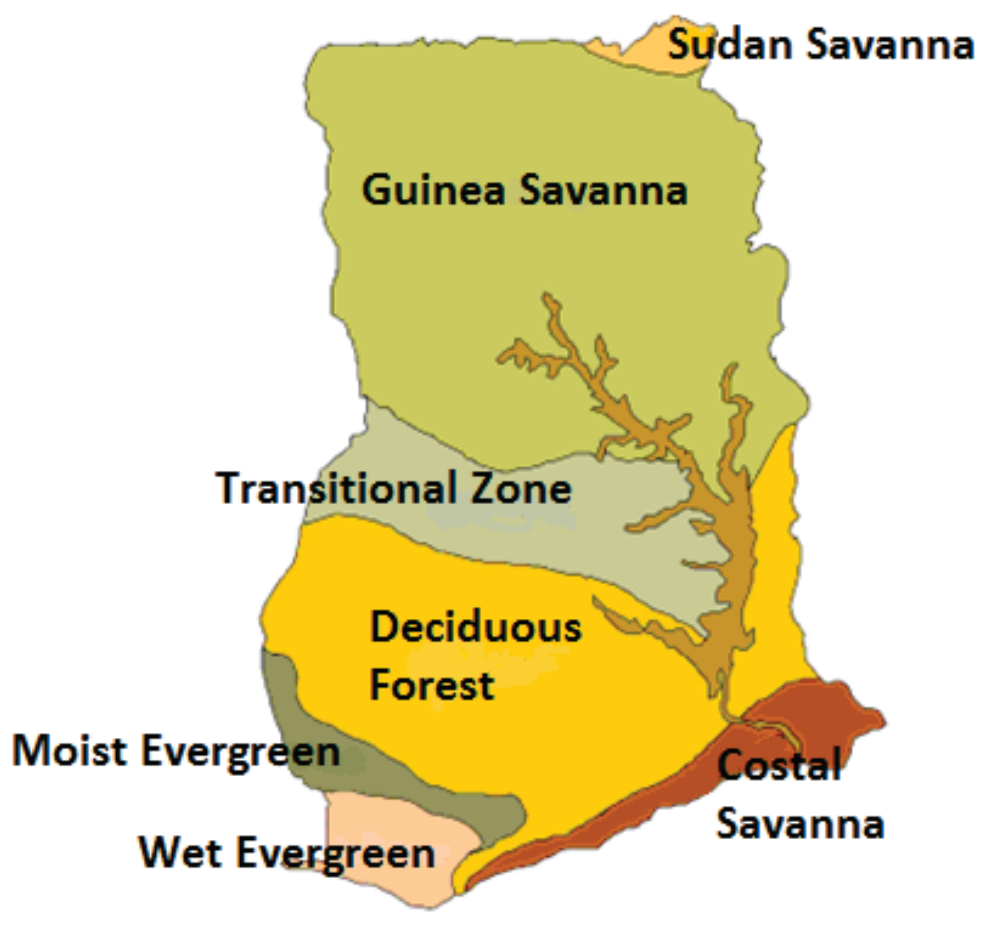

Figure 5: Ecological zones of Ghana (FAO 2004)

Source: http://www.apipnm.org/swlwpnr/reports/y_sf/z_gh/gh.htm 


\section{Colonial history of Ghana}

The boundaries of modern Ghana at its formation were those delineated by the old British colony of the Gold Coast and that of the British-mandated Togoland (Fage, 1966). This area was a piecemeal expanse of land which did not correspond to any ethnic or geographic divisions, and extended the coastal shore of Ghana from the Tano River delta to the west to the Volta River delta to the east (Figure 6). This stretch of land was known into the 19-century as the Gold Coast (Fage, 1966).

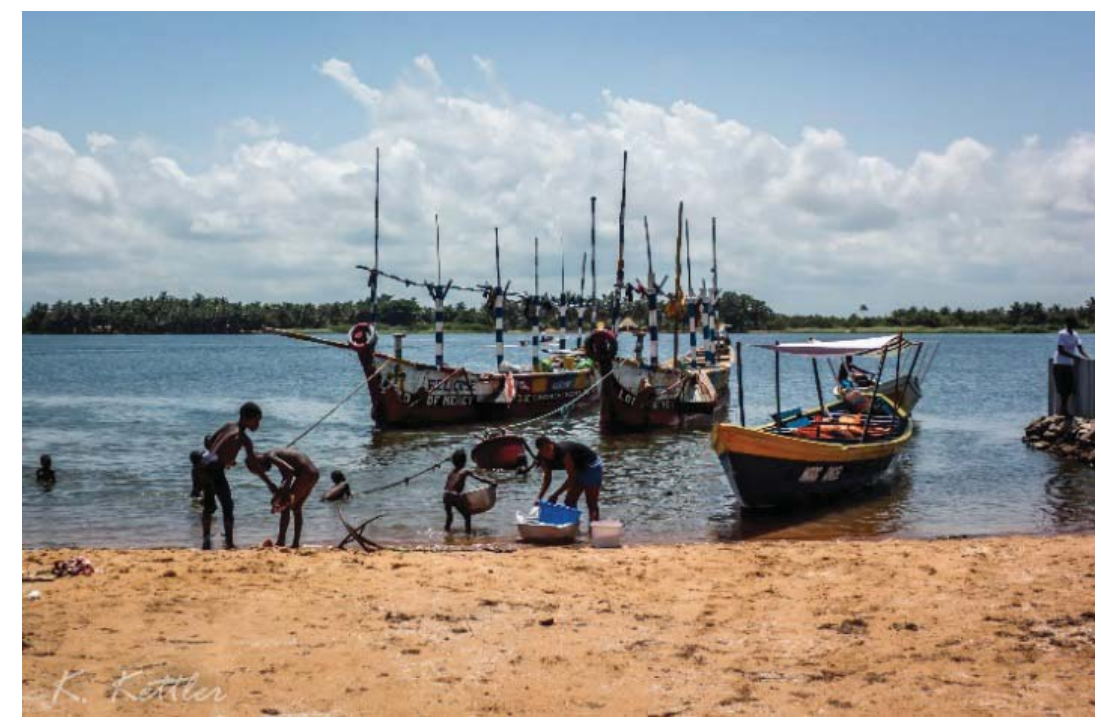

Figure 6: Fishermen and bathers in the Volta River delta. Photos by Kenneth Kettler.

Early Portuguese settlers explored the African continent in the search for gold.

Eventually, Portuguese settlers reached the coast of Ghana which was so abundant in gold that they named it "A Mina", the mine (Fage, 1966). In 1482, the castle of Sao Jorge da Mina, today known as Elmina, was established as a stronghold to maintain a permanent trading post of the opulent site (Dumett, 1998). However, the Portuguese monopoly of the West African maritime trade came to its peak in 1598, and decline 
followed as British merchants started taking control of Portuguese footholds (Fage, 1966).

British interests in West Africa were intensified as they realized prosperity in the new American empire rested on the supply of slave labor and gold, therefore British soldiers acquired Elmina from the Portuguese to monopolize access to slave labor (Fage, 1966). As British presence in Ghana became more permanent, they began taking more of a stance in local political issues. Soon, British settlers became the most influential power in Ghana. The bond of 1844 was negotiated with surrounding local chiefs that granted British jurisdiction through indirect rule over the area as protection from outside threats. (Danquah, 1957). Over time, more chiefs signed the treaty which allowed Ghana to become a British colony.

British rule during colonization was exploitative. Africans, that were once dividied, started to form a partisanship against British imperial power. During WWII Africans were recruited to fight alongside the British but were offered no remuneration for their services. This ignited a movement towards political freedom from British power. (Naylor, 2000). Nationalism quickly accelerated in Ghana, which transferred the focus of government from British officials into the hands of Ghanaians when in 1947, "the Big Six" founded the first nationalist movement with the goal of Ghana becoming selfgoverned (Naylor, 2000). Elections were held, and in 1957 Ghana gained independence from the British as the first independent country of sub-Saharan Africa (CIA, 2012). 


\section{Economy of Ghana}

Ghana has been recognized as a stable and steady democracy since 1992. Its GDP is $\$ 88.5$ billion dollars, ranking Ghana at 78th in the world (CIA, 2012). Per capita income is $\$ 3,400$, categorizing Ghana as a lower middle income country (CIA, 2012). Gains have been made by working to develop and improve a competitive and economic business environment and providing a relatively sound governance. However, $28.5 \%$ of the population still live below the poverty line. Ghana is rich in natural resources and agricultural production. The three main sectors that contribute to Ghana's GDP are industry, agriculture and service which make up a labor force of 12.07 million with an unemployment rate of only 4.5\% (CIA, 2012).

The service sector accounts for $49.8 \%$ of the national GDP and is $29 \%$ of the work force (CIA, 2012). This is mainly driven by transportation services followed by public administration, hospitality and maintenance (GSS, 2013).

Due to high poverty levels in the north, many young girls to migrate to southern cities as a means of obtaining income. This phenomenon, often called "Kayayo", causes girls at ages of 9-28, to participate in the sale of food stuffs in markets or by roadside. The conditions that young girls face make them vulnerable to harsh conditions, remove them from the safety and the guidance of their family, and deprive them of an education.

The industry sector in Ghana accounts for $28.7 \%$ of the GDP and $15 \%$ of the labor force (CIA, 2012). The industry sector is driven by construction, manufacturing, and mining (GSS, 2013). Ghana is Africa's second largest producer of gold next to South Africa. New areas in industrial development include drilling for oil. In 2010, Ghana started the production of offshore drilling in Ghana's Jubilee field in hopes of boosting 
the economy.

Agriculture export contributes the smallest GDP percentage at 21.5\% (CIA, 2012). The main industrialized crops and resources are cocoa, palm oil, timber and shea nut, where staple crops include rice, maize, cassava, and yam (CIA, 2012) (Figure 7). Even though agriculture contributes the smallest amount to GDP, it is composed of 56\% of the work force (CIA, 2012). This is problematic to areas of the south of Ghana where land-related law make obtaining land difficult. Land is a sign of wealth and is often inherited which puts people who live in poverty at a disadvantage (Naylor, 2000). Women are at a particular disadvantage since they are often limited to land rights in a patriarch society.

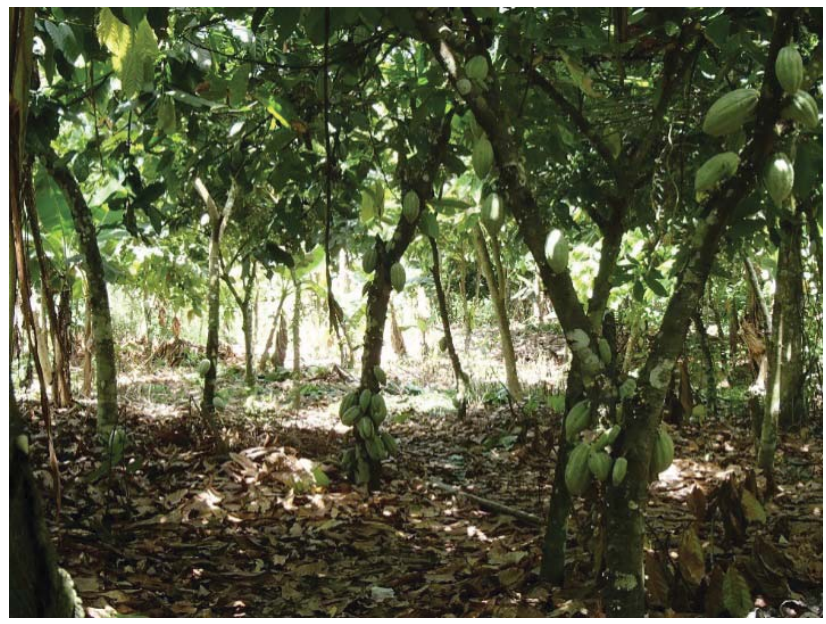

Figure 7: Typical cocoa farm located in the Eastern Region.

Ghana has worked to improve government effectiveness, decrease corruption and strengthen public institutions, which has gradually led to the economic improvement of the service, industry, and agriculture sectors. Although, Ghana is making small economic 
gains, it is often overshadowed by structural mismanagement of institutions and lacks the fundamentals necessary to sustain economic growth. 


\section{CHAPTER 3: STUDY AREA BACKGROUND}

\section{Upper West Region of Ghana}

The Upper West Region (UWR) of Ghana spans an area of $18,476 \mathrm{~km}^{2}$, and is the $7^{\text {th }}$ largest region of Ghana's ten regions. Ghana's Upper West Region borders the Upper East region to the east and the Northern Region to the south. The Republic of Burkina Faso borders the UWR to the north and west. There are nine districts within the UWR: Jirapa, Lambussie, Karni, Lawra, Nadowli, Sissala East, Sissala West, Wa East, Wa Municipal, and Wa West. Wa, located in the Southwest corner, is the capital of the region. The study site is located in the Wa East district, in the Bulenga settlement(Figure 8).

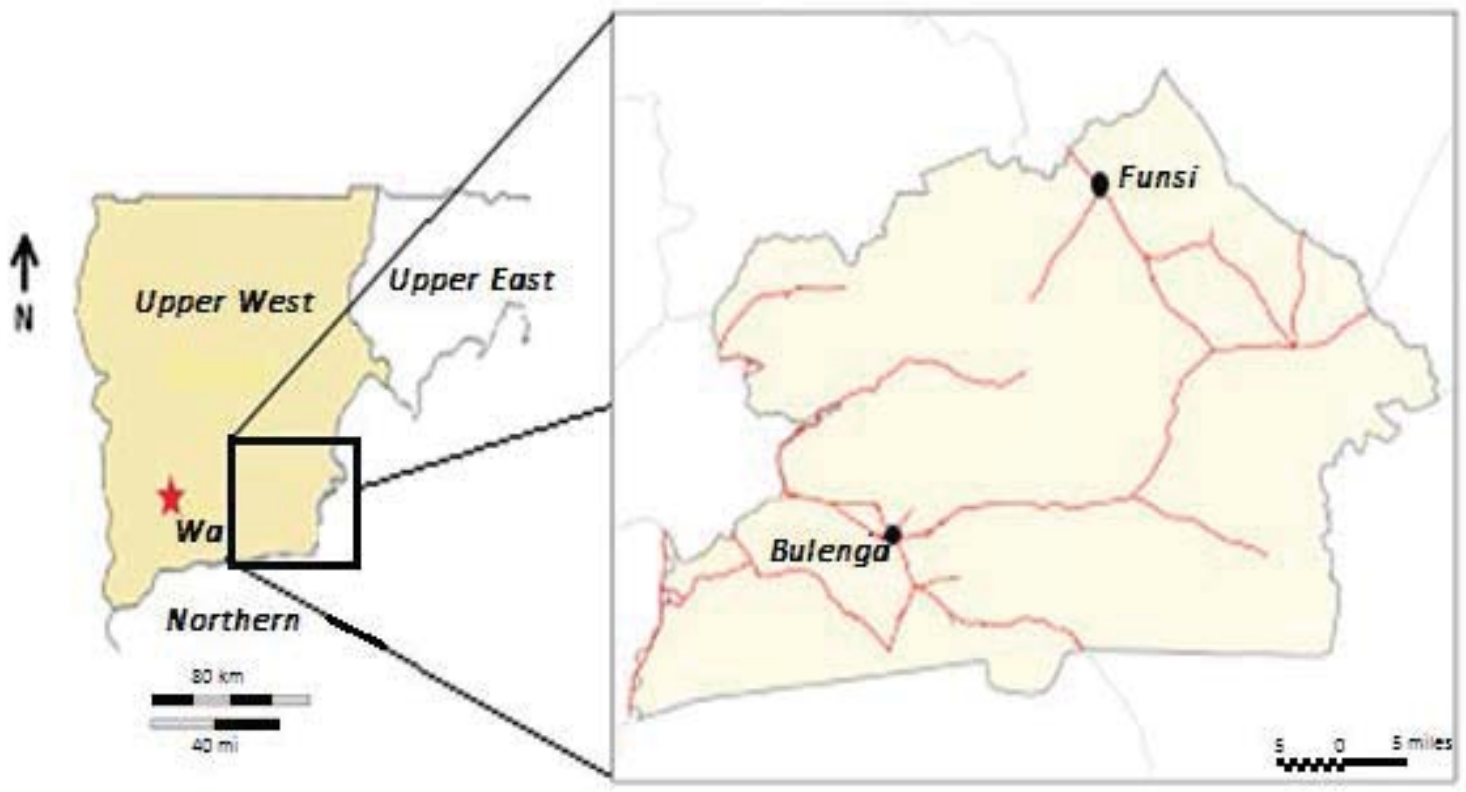

Figure 8: Wa East district located in the Upper West Region of Ghana Source: http://d-maps.com/ 


\section{People of Upper West Region of Ghana}

The UWR has a population of 38 people/ $\mathrm{km}^{2}$, the lowest population density of the regions. During precolonial times, northwest Ghana was made up of a lattice of overlapping networks where families and relatives relied heavily on subsistence agriculture (Lentz, 2000). Many relations in the region were determined regardless of language and custom. This is apparent through common cultural customs that are present today. Because of the low amounts of rainfall and higher poverty levels, the construction of traditional mud houses is common among northern Ghanaians (Figure 9). The original local societies of the UWR were the Sissala and the Dagara, which are still present today (Lentz, 2000). Before colonialization, these settlements spanned large areas of West Africa. However, today Sissala ethnic groups can be found in the northeast part of the UWR, and Dagara in the northwest of the UWR. These names were derived from the characteristics of the people. Sissala, means "remaining together", while Dargara, means "mobile people" (Lentz, C., 2000).

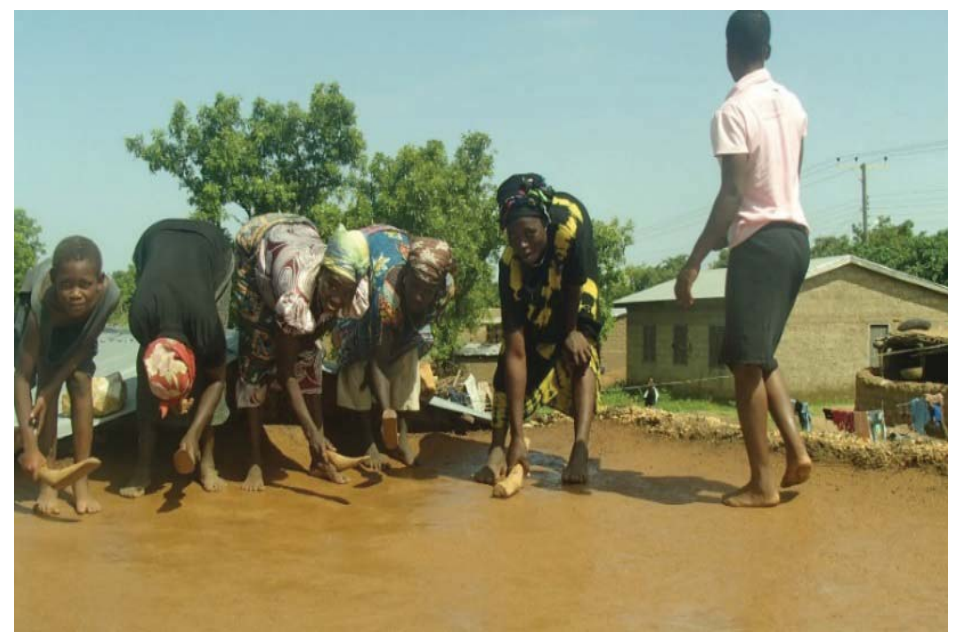

Figure 9: Women in a family packing down a mud roof. 
The formation of Wa was believed to have been established as a popular trading post and resting place along a historical trade route from northern Africa. As Muslim proselytizers entered into northwest Ghana from northern Africa along this trade route. They offered educational services to many of the local people which sparked the spread of Islam in Wa. Soon, a boundary was created between the educated Wale Muslims and the non-Muslims surrounding it.

Apart from the kingdom of Wa, northwest Ghana consisted of family clans which developed through patrilineal lineages. As clans expanded, social structures developed. Power is inherited by the landlord, the chief and elders. The landlord's authority consists of the appropriation of land while the chief and elders regulate political issues of the village. This system varies throughout northern Ghana. However, in Bulenga, the landlord and chieftaincy were thought to have been split between two brothers of the same clan. The older brother, first settled the land and became the landlord. He then appointed his younger brother as the chief. The chief is selected by the landlord therefore creating a balanced system. As decentralization developed in Ghana, the formation of the District Assembly system was created as a substantial link between the smaller districts to higher political organizations (Naylor, 2000). Assemblymen are appointed from each village with in a district as a political representative of that area. Assemblymen often work closely with the chief and elders to relay information to higher political systems.

The idea of "tribe" did not exist until British rule in the $17^{\text {th }}$ century (Lentz, 2000). Later in the 19th century, as northwest Ghana was invaded from the south by British colonialist, they acquired local nomenclature to designate locations of different "tribes" (Lentz, 2000). The Grusi (wearers of leaves), Lobi (those who practice the loor 
cult), and Dagaba (those who cannot be understood) were determined regardless of how these groups identified themselves (Lentz, 2000). Through British understanding of societal classifications, Wa was seen as center state. Therefore, colonizers were drawn to Wa. (Wilks, 1989) (Figure 10).

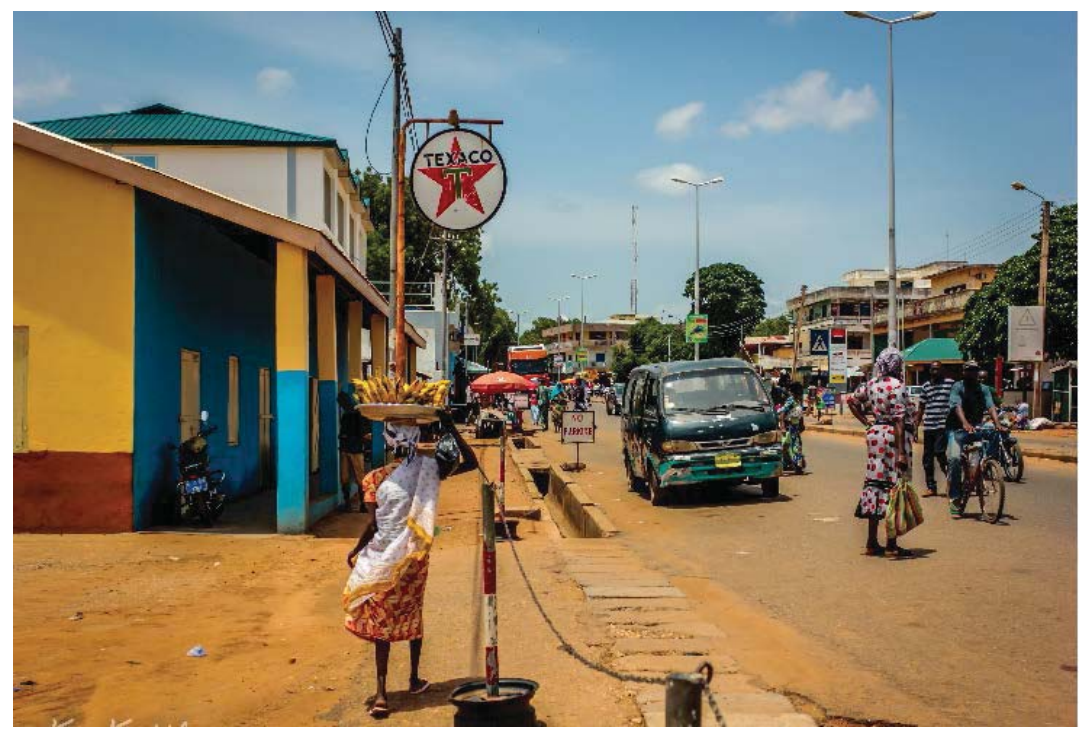

Figure 10: Main road in Wa. Photo by Kenneth Kettler

\section{Climate and Topography of the Upper West Region of Ghana}

The Upper West Region is located in the Guinea-savannah zone of sub-Saharan Africa (Figure 5). The climate in the UWR is tropical equatorial and has a uni-modal rainfall pattern with a rainy season during May - October. The average annual rainfall is 800 - 1200 mm (Gerkin et. al., 2001). Temperatures reach their highest during November - April $\left(42^{\circ} \mathrm{C}\right)$ and lowest during December - January $\left(22^{\circ} \mathrm{C}\right)$. The dry season begins when the winds change from the south westerly Atlantic winds to the dry dusty West African trade winds from the Sahara desert, a weather phenomenon known as Harmattan. 
The UWR is located in the high-plains which are a series of high plateaus with occasional rocky outcrops characterized as birrimian granite. The elevation ranges from $200-350 \mathrm{~m}$. The highest point is a dome-shaped granite monolith that reaches $435 \mathrm{~m}$, located north of Wa. There are two major rivers, Black Volta River which runs along the western boarder and the Kulkpong River which flow along eastern border. Soil types associated in this area are sandy loams and alluvial clay deposits (MoFA, 2013).

Vegetation is dominated by scattered trees, shrubs and grasses. The most common tree species are shea (Vitellaria paradoxa), baobab (Adansonia digitata), and dowa dowa (Parkas biglobosa) (Gerkin et. al., 2001). Crops and livestock are integrated within the scattered mature trees that occur in cultivated and recently fallowed fields. This farming system is known as "agroforestry parkland" (Boffa et al., 2000).

\section{Economy of Upper West Region of Ghana.}

The major economic activity of the region is semi-subsistence agriculture and small scale agro-processing. This accounts for $80 \%$ of the UWR labor force (GLSS, 2006). Sixty three percent of the total arable crop area is devoted to staple crops such as maize (Zea mays), yam (Dioscorea rotundata), rice (Oryza glaberrima), sorghum (Sorghum bicolor), pearl millet (Pennisetum glaucum), and cassava (manihot esculenta) (MoFA, 2013) (Figure 11). Cassava is known throughout West Africa as the poor man's food. In Ghana it is made into the Ghanaian dish called Konkonte or "face-the-wall", this is to hide from passersby so that you are not seen eating it. Staple crops are often supplemented by crops such as okra (Abelmoschus caillei), pepper (Capsicum annum), and tomatoes (Lycopersicon lycopersicum) (MoFA, 2013). These crops are often used in the preparation of stews and soups. 


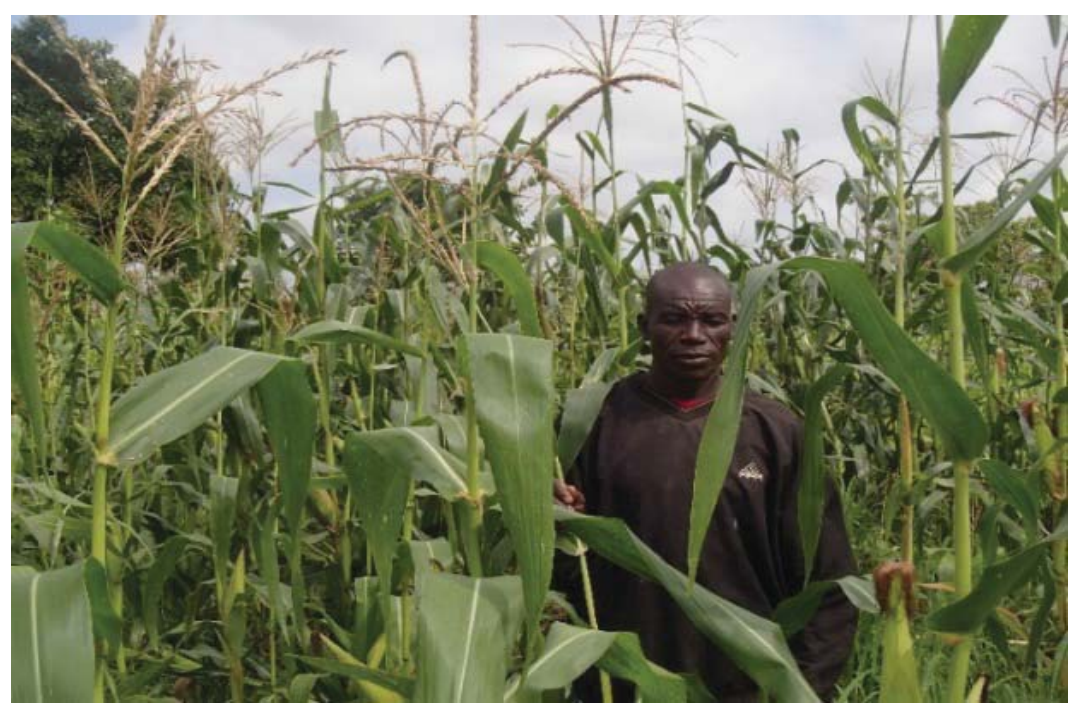

Figure 11: Farmer in his maize field in Bulenga

Livestock and poultry are reared on a limited scale. Grazing land is now being lost to intensive cultivation of agricultural lands (Karbo, A., 1998). Cattle are often reared and transported for sale in Wa or Kumasi, whereas goats, sheep and chickens are eaten for personal consumption (Figure 12). Animals are free-range since the grassland environment is conducive to grazing. This attracts nomadic Fulani herdsmen from different parts of West Africa to this area. Ghanaians often employ Fulani to herd their cattle. However, conflict between Ghanaians and Fulani herdsmen is commonly caused by livestock trampling crops (Karbo, A., 1998). 


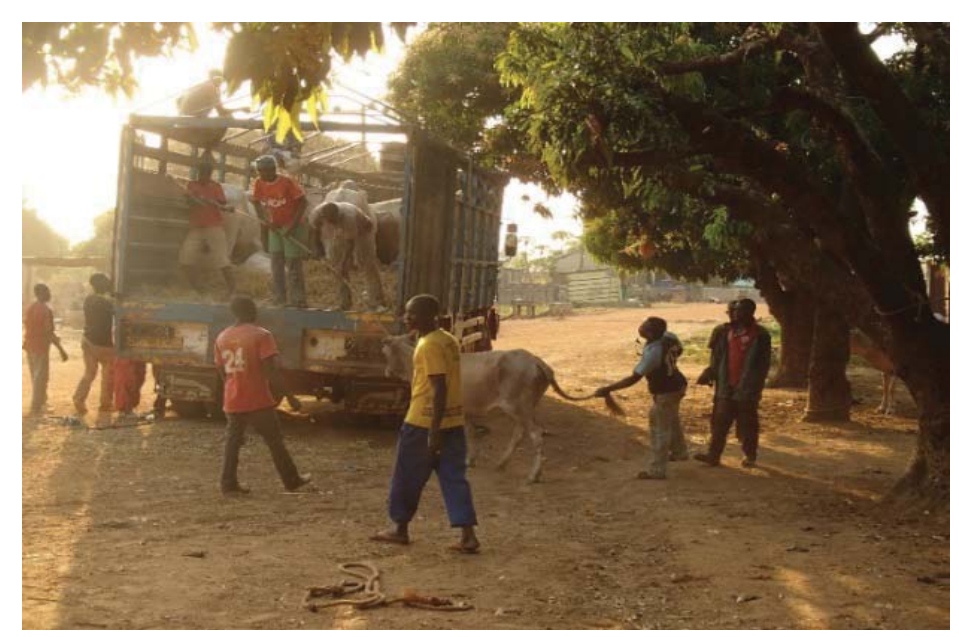

Figure 12: Loading cattle to be transported for sale.

Most people supplement their farming income with other income generating activities including additional trade such as carpentry, food preparation or by adding value to food crops (Figures 13A, 13B). For example, many women enhance the value chain of raw groundnut crops by preparing Kepe (pronounced kay - pee). Kepe is a snack served with tea, and is made from a multi-step process where women extract oil from milled peanuts. The remaining meal is then rolled into balls and dried for consumption (Figure 13C, 13D). The cultural drink, Pito, is a communal drink and often sold on market days and another activity that can enhance household income (Figure 13E, 13F). It is an alcoholic beer made from fermented millet. Pito is produced throughout the northern expanse of Ghana, and is not commonly found in the southern region 

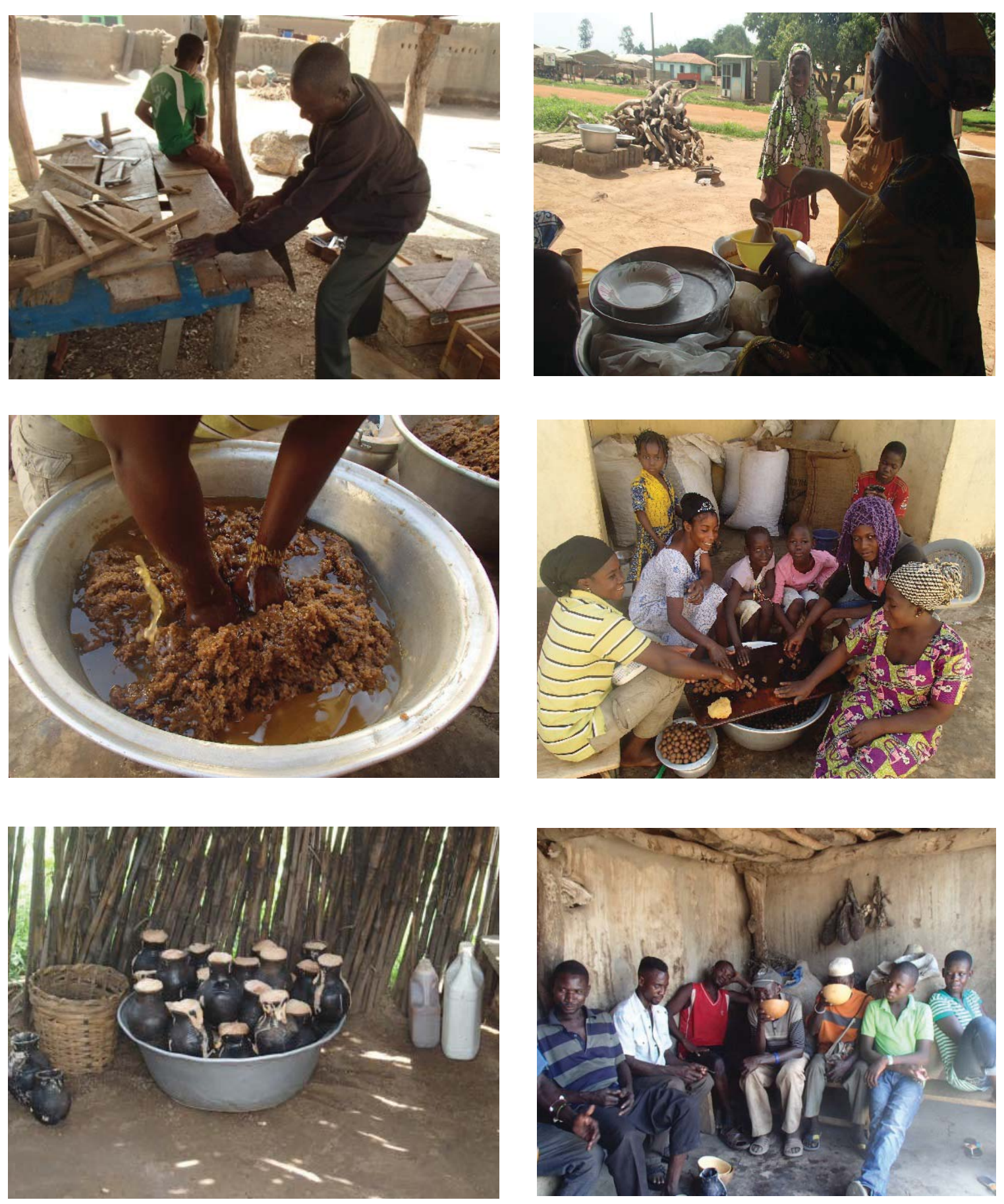

Figure 13: Left to right (A) Local carpenter in Bulenga. (B) Local women of Bulenga selling soup for added income. (C) Beginning process of Kepe production. (D) Women rolling Kepe into balls. (E) Brewed pito waiting to be sold. (F) Men at market day enjoying pito together at the drinking spot. 
More recently, the possibility of finding gold has been attracting illegal mining as another means of obtaining income (Yangmaadome, 2012) (Figure 14). Gold mining has contributed to the difficulty of developing villages. People are attracted to the idea of "striking it rich" and spend their time and resources mining for gold. It can cause a decrease in classroom attendance as many school children will abandon classes in order to mine for gold. Illegal gold mining attracts many unfamiliar people which has the tendency of introducing sexually transmitted disease such as AIDS into the village (Yangmaadome, 2012).

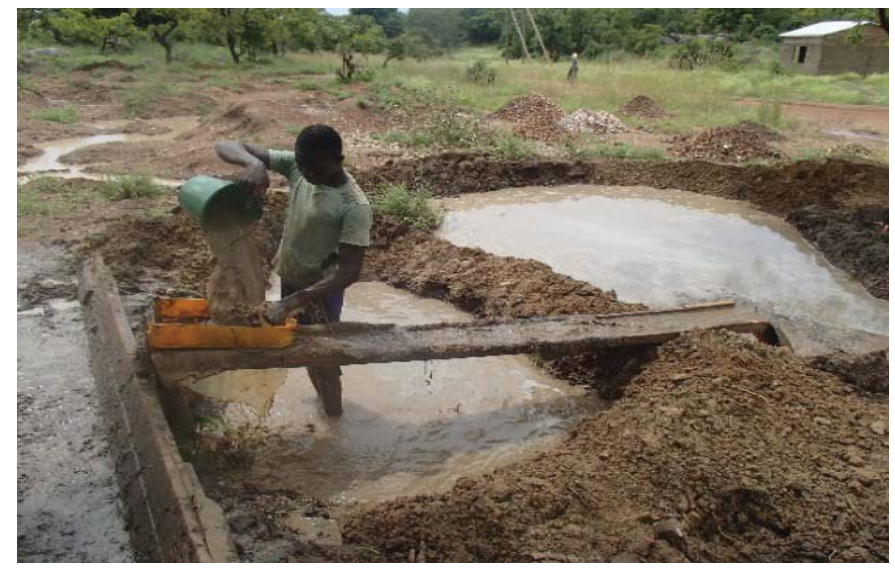

Figure 14: Illegal gold miner separating the gold filled silt from sand

Methods for extracting gold are dangerous for the environment and village health (Yangmaadome, 2012). Pumped water from the local dam is used in separating small flecks of gold from silt and sand. In order to remove gold from the sand, sodium cyanide is used. Since this work is accomplished near the local water source, many people are affected by the cyanide run-off. Farmers who use irrigated water for their dry season farming, women who fetch water for household washing, fishermen, and livestock are all effected by this contaminated water. The large number of people using this water in 
mining procedures has caused the water levels to decrease at the local dam, making it difficult for farmers to supplement their income and provide food for their families.

\section{Agriculture reform and poverty of Upper West Region of Ghana}

The three northern regions of Ghana are ranked as the three most poverty stricken areas of the country. According to the livelihood standards used by the Ghana Living Standard Survey (GLSS), most of the poverty in Ghana is concentrated in populations of "food crop farmers". The three northern regions make up $46 \%$ of the population of Ghana, where $70-80 \%$ of the households have stated that their main form of income is farming (Shepherd et.al, 2005) (Figure 15). Many families choose to remain in agriculture because they do not see how they would be able to make a living outside of the agricultural sector. Monetary investment is difficult because farmers often have limited assets, such as land and labor (Al-Hassan \& Poulton, 2009). Also, farmers in Ghana are situated in high risk environments that make them vulnerable to shocks such as drought and diseases.

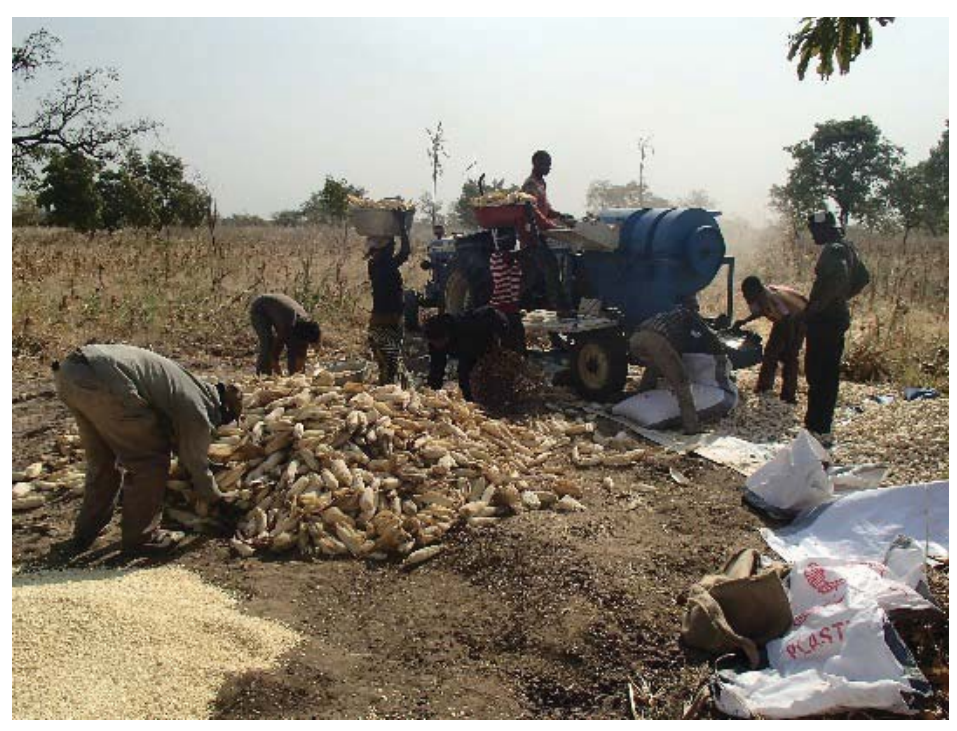

Figure 15: A common form of maize threshing. 
In the 1970s, the northern regions were identified as having economic potential in the agricultural sector because of the vast areas of arable land (MoFA, 2013). Social programs were put in to action to move the agricultural sector forward into commercialization through the development of agro-processing centers, subsidies for tractor service and fertilizers, as well as providing market linkages with the southern regions. However, these ventures were often seen as costly and inefficient (Al-Hassan \& Poulton, 2009). Therefore, in the 1980-90s, during the structural adjustment reforms, many of these programs were eliminated. As most agricultural programs were withdrawn, many of the large commercial cash-crop farms collapsed and people moved back to subsistence style farming (Al-Hassan \& Poulton, 2009).

Today, the northern regions rely heavily on donor support to aid in agricultural development which include but are not limited to: The Association of Church-based Development NGOs (ACDEP), The Adventist Development and Relief Agency (ADRA), and the United States Agency for International Development (USAID). A need for agricultural development policies was recognized by the Ghanaian government, however they have not been implemented (Al-Hassan \& Poulton, 2009). Therefore, programs instituted by various interest groups and stakeholders are the main forms of agricultural enhancement in order to reduce constraints (Al-Hassan \& Poulton, 2009). Many aid interventions have focused on food programs and improving small farming enterprises to either help poor farmers from the bottom-up, for example with feeding programs, or topdown through large stakeholder farmers who provide service to many small farmers. In Bulenga, many programs such as that have been initiated have provided farmers with 
market linkages, education on improved farm technologies and farming equipment (Figure 16).

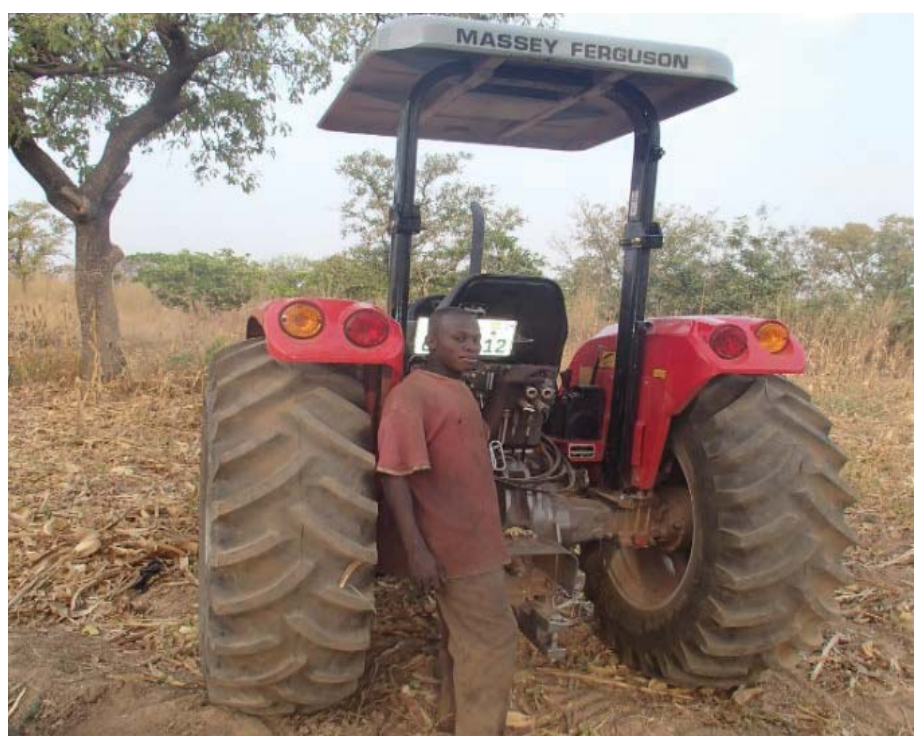

Figure 16: Farmer posing next to his tractor that he acquired through an aid program

\section{Agroforestry Parklands of West Africa}

Agroforestry parklands represent a majority of the agricultural landscape under subsistence-oriented farming in semi-arid West Africa. Agroforestry parklands of West Africa are characterized by the growth of well-maintained mature trees which are scattered on cultivated fields, and are the result of both environmental and human influences (semi-natural) (Augusseau et al., 2006). The most common form of subsistence farming encountered in northwest parklands is the bush fallow-system. Bushfallow systems can be described as a fixed rotation of farmed land, owned by the same farmer. This system evolved to restore soil fertility, and is the main driver of bush-fallow systems (Benneh, 1972). Economic trees, such as $V$. paradoxa, are allowed to remain on farmed land in order to maintain preferred secondary farm characteristic such as desired 
microclimates for co-occurring staple crops (Bayala et al. 2002). However, the geographically harsh climate and distinct seasonality makes this area susceptible to poor soil conditions, short growing seasons and an increase in the incidence of drought. As these factors become more and more severe farmers are continually changing and adapting to achieve optimal crop production and soil fertility.

Shea (Vitellaria paradoxa) is the most frequently found tree species observed within agroforestry parklands of northern Ghana (Lovett and Haq, 2000). Shea is a multipurpose, income generating species which has significant cultural ties to the people and their land. V. paradoxa provides many non-timber resources and income from food, medicines, and shea butter. The fruit of $V$. paradoxa is a nutritional supplement to Ghanaian diets. Fruiting period of shea plays a vital role in providing nutrient resources to local people in between cropping seasons of staple crops (Teklehaimoanot, 2004, Pouliot, 2012). The timber of $V$. paradoxa is durable and resilient; therefore, it is used in making farming tools and fuel for firewood (Figures 17A, 17B). Shea butter oil extracted from the shea nut is used mainly as cooking oil. Next to palm oil, shea butter is the second most important oil crop in Africa (Moore, 2008) because shea is able to grow in semi-arid environments that are unsuitable for palm growth. Therefore, shea oil is the primarily used as cooking oil in West Africa. In the 1970s, shea butter was recognized as the only available vegetable oil that could substitute as a cocoa butter equivalent, mainly for its use in cosmetics and chocolate (Puliot 2012). 

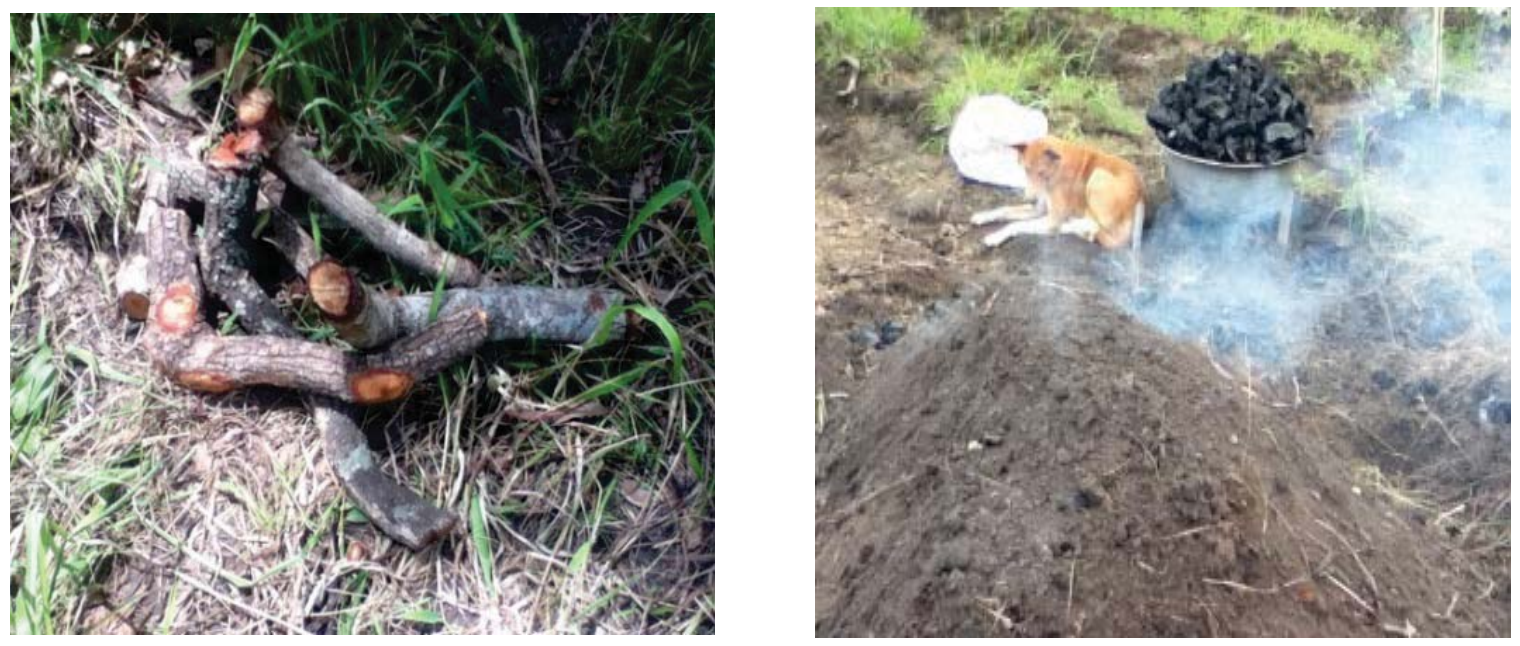

Figure 17 (A) Cut V. paradoxa branches to make hand hoes. (B) Burning shea tree stump for charcoal

Shea is important to both men and women; however, women are often associated with collecting shea. Since shea is considered a women's domain, a cultural stigma is placed on men who collect shea and they are seen as doing the work of a woman (Figure 18A, 18B).
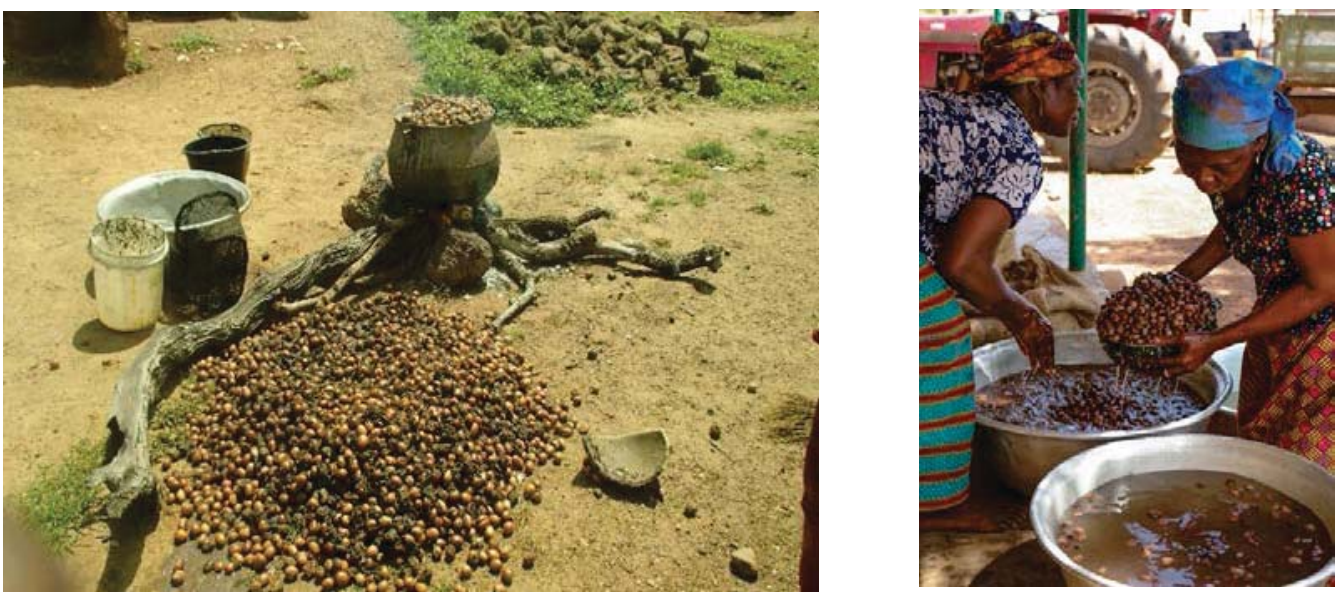

Figure 18: (A) Dried shea nuts are parboiled in preparation for making shea butter. (B) Women working together to prepare shea butter. 
Environmental factors can impact tree growth and propagation, such as bush burning (Figure 19). Bush burning is a common farming practice used to clear fields for farming. Intense fires burn flowers and kill regenerated seedlings in fallow fields. Also, plant parasites, such as African Mistletoe (Genus: Tapinanthus), can enable secondary pathogens to attack the tree, resulting in tree death (Orwa, 2009).

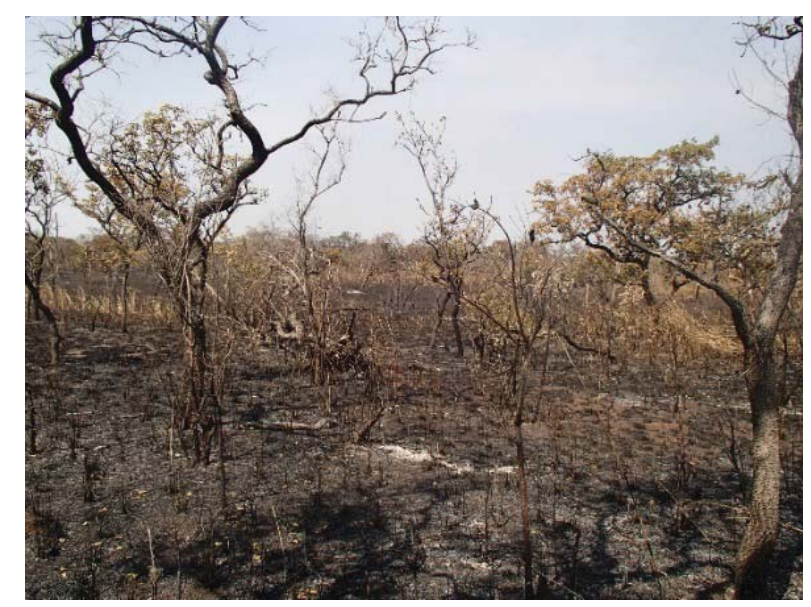

Figure 19 Recently burned field of $V$. paradoxa.

\section{The Village of Bulenga}

The study site is located in the Wa East District in the Bulenga settlement. The citizens of Bulenga identify themselves as the Wala people, and they are predominately Muslim (Figure 20A). There are approximately 3,000 people living in Bulenga. Bulenga is one of the major market towns of Wa East, allowing farmers and traders to connect to larger markets in Wa (Figure 20B). Funsi is the district capital of Wa East, and is located $115 \mathrm{~km}$ southeast of the regional capital of Wa. The primary occupation of Bulenga is farming; the people rely heavily on agriculture to maintain their livelihoods. This makes many of the people vulnerable to external shocks such as intense climatic changes and volatile markets. 

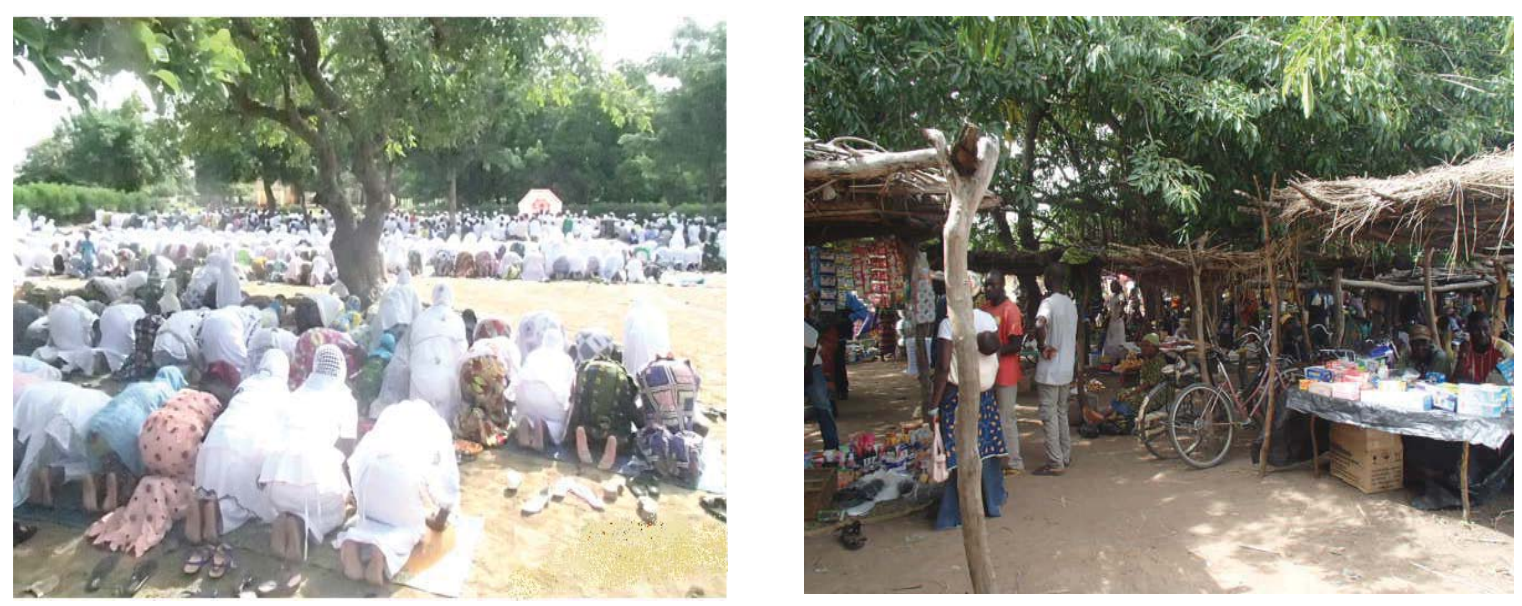

Figure 20: (A) Celebration of Eid el-Adha in Bulenga. (B) Market day in Bulenga.

The lack of infrastructure to the UWR has caused isolation relative to other districts, therefore the UWR has been at a disadvantage in terms of receiving socioeconomic services in the past. This includes receiving services such as maintained roads, electricity, medical clinics, and water supply systems. However, the relation of Wa East to the regional capital has allowed the allocation and transfer of services and facilities to become more accessible to certain settlements of Wa East. Bulenga, ranks second in the district of number of service received (MoFA, 2013). Bulenga is fortunate in that they have electricity and they are the location of the local clinic. Many students migrate to Bulenga because of the two junior high schools in the area, while many settlements only have primary and junior high schools. Bulenga is also the location of the main taxi station that connects Wa East villages to Wa. 


\section{SECTION 2: RESEARCH}




\section{CHAPTER 4: INTRODUCTION TO RESEARCH}

Farmers in sub-Saharan Africa play an influential role on the interaction between trees and crops when managing agroforestry parklands. They manipulate tree densities and spatial composition of parkland trees in order to minimize the interactions between trees and crops. Vitellaria paradoxa (shea trees) play a large role in farming systems for their cultural value in non-timber products such as cooking oil, medicine, and as a food source during dry season. Therefore, these trees are often left to remain on the field (Pouliot, 2012).

In agroforestry systems, trees and crops are grown in association and may compete for multiple resources, including water, nutrients and light. In semi-arid environments, water and soil nutrients are the most limiting resources (Rhoades 1997). Because competition is often more favorable to trees, farmers will often reduce the number of trees on their farms in order to promote the growth of their crops (Sanou et al. 2012). Kelly et al. (2004) found that farmers predetermine the spatial patterns of trees in order to produce higher yields of crops. When comparing two sites in Mali, it was found that shea trees became increasingly scattered (single) from bush to fallow to field. In farmed areas, farmers put limited thought into following a specific spacing rule (Kelly et al. 2004).

When trees are selected for clumped distributions, less light is available to the understory. Kessler (1992) found that sorghum production decreased under the crowns of parkland trees due to a 50\% decrease in sunlight. In an alley cropping system of maize with Senna spectabilis, maize yields decreased by $40 \%$ because trees were able to utilize more soil moisture even though their roots were below the rooting zone of crops (Ong 
and Leakey, 1999). In Guinea Savannah vegetation zones of Burkina Faso, although phosphorous slightly increased under the canopies of $V$. paradoxa, crop yield still declined by up to $70 \%$ as a result of competition for resources such as nutrients and water (Kater et al., 1992)

Previous research on tree crop interactions of parklands focused on single tree influences with associated crops (Kessler, 1992; Kater et al., 1992 Campbell, 1994; Jonsson, 1999). However, Boffa (2000) stated that focusing on the effects of individual trees on crops leads to a lack in understanding of tree-crop interactions, and that measuring the space between two trees was more appropriate. However, this still does not give a full understanding of tree-crop interactions when trees are aggregated, and a more in-depth assessment on the interactions between crops within aggregated trees versus scattered trees is needed.

The tendency to maintain certain spatial patterns of parkland trees also involves a socio-cultural contrast between the preferences of women and men farmers. The preferences of male and female farmers often originate through household gender roles. Women are typically in charge of cooking, therefore maintaining more $V$. paradoxa for the collection of shea that is produced into cooking oil is important for women (Kiptot \& Franzel, 2012). Conversely, male farmers are more interested in reducing the presence of trees on the farm to minimize tree-crop competition that could result in decreased annual income (Lovett \& Haq 2000). In West Africa, women often have limited access to land rights and therefore have limited decision making power in farming practices and management of trees on the farm (Quisumbing et al. 2013); therefore women often have little or no power in household and on-farm decision-making (Asse' \& Lassoie 2011). 
However, households that do allow a mutual agreement that mixes intensive and traditional farming practices could have the greatest ability towards maintaining tree management strategies that are the most ecologically sustainable and profitable (Asse' \& Lassoie 2011).

Traditional land-use systems have changed over recent years due to agricultural development. Traditional fallow systems which favor tree regeneration have been replaced by the use of chemical fertilizers in order to meet high production demands (Boffa, 2000). Farmers often see trees as obstacles to mechanized plowing, and they may assume that crop yield significantly decreases under tree crowns due to light competition. Farmers may be motivated to remove trees from the fields in order to meet their economic demands. It is important to have a better understanding of how the spatial distribution of trees affects associated crops in order to maximize maize production, while also maintaining the presence of V.paradoxa. The aim of this study was to determine the most beneficial spatial distribution of $V$. paradoxa trees on maize crops in parkland systems of Ghana with respect to overall productivity of maize, as well as how gender will be a contributing factor of on farm management based on the farmer's gender based needs.

I hypothesized that maize production is more limited by light availability than by water availability; therefore, maintaining trees in scattered distributions of individual trees is better for maize production than maintaining trees in clumps. It is expected that maize yield and growth will increase with increasing distance from stems for both single and clumped trees due to increasing light availability, and will be higher overall under single trees than clumps, due to less canopy cover overall under single trees. Maize yield 
and growth will be more strongly correlated with light availability than water availability.

Lastly, gender will be a contributing factor when determining the appropriate spatial distribution of shea trees on a farm based on farming preferences. 


\section{CHAPTER 5: MATERIALS AND METHODS}

Yield of maize (Zea mays) associated with individual trees, clumped trees, and open fields were measured. Soil moisture and light availability were measured in order to determine how $V$. paradoxa trees affect resource availability and yield of maize in either clumped or scattered distributions. In addition, semi-structured interviews were given to male and female farmers to understand the importance of $V$. paradoxa and determine social influences of $V$. paradoxa tree distribution.

\section{Site Selection}

Research plots were located in village located in the Guinea-savanna zone of the

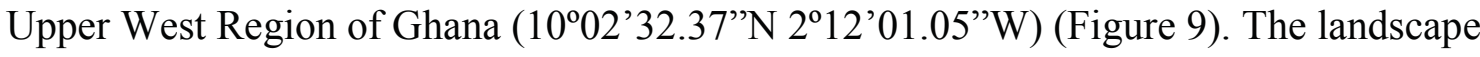
is located approximately 180 - $1300 \mathrm{~m}$ above sea level. The climate is tropical equatorial and has a uni-modal rainfall pattern which occurs during May - October. The average annual rainfall is $800-1200 \mathrm{~mm}$ (Gerkin et. al. 2001). Temperatures reach their highest during March - April $\left(42{ }^{\circ} \mathrm{C}\right)$ and lowest during December - January $\left(22^{\circ} \mathrm{C}\right)$. The dry dusty West African trade wind, known as Harmattan, occurs during November - April.

Soil types found in this area are sandy loams and clay deposits (MoFA 2013). Vegetation is dominated by scattered trees, shrubs and grasses. The most common tree species found include shea (Vitellaria paradoxa), baobab (Adansonia digitata), and dowadowa (Parkia biglobosa) (Gerkin et. al. 2001). Crops and livestock are integrated within the scattered mature trees that occur in cultivated and recently fallow fields (Boffa et al. 2000). Farms were selected based on the presence of $V$. paradoxa in maize cropping fields. Six single trees and seven tree clumps of $V$. paradoxa were studied on five different farm fields that were managed by male farmers. Farms ranged in size from 
1-3 hectares to measure their effects on maize crops and environmental factors (Table 1). Clumped trees were groups or aggregations of 3-11 trees, and single scattered trees were isolated from other trees by at least $15 \mathrm{~m}$ to ensure that influences from other trees would not be a factor in maize yields or environmental factors (Figures 21A, 21B, 21C).

Table 1: Number of single and clumped trees per farm

\begin{tabular}{|c|c|c|c|}
\hline Farm ID & $\begin{array}{c}\text { Single } \\
\text { Trees }\end{array}$ & $\begin{array}{c}\text { Number of } \\
\text { Clumps }\end{array}$ & $\begin{array}{c}\text { Number of } \\
\text { Trees in a } \\
\text { Clump }\end{array}$ \\
\hline MAH & 1 & 1 & 9 \\
\hline ECO & 1 & 1 & 6 \\
\hline SED & 0 & 1 & 5 \\
\hline SAL & 2 & 2 & 6 each \\
\hline MOS & 1 & 2 & 3 each \\
\hline
\end{tabular}
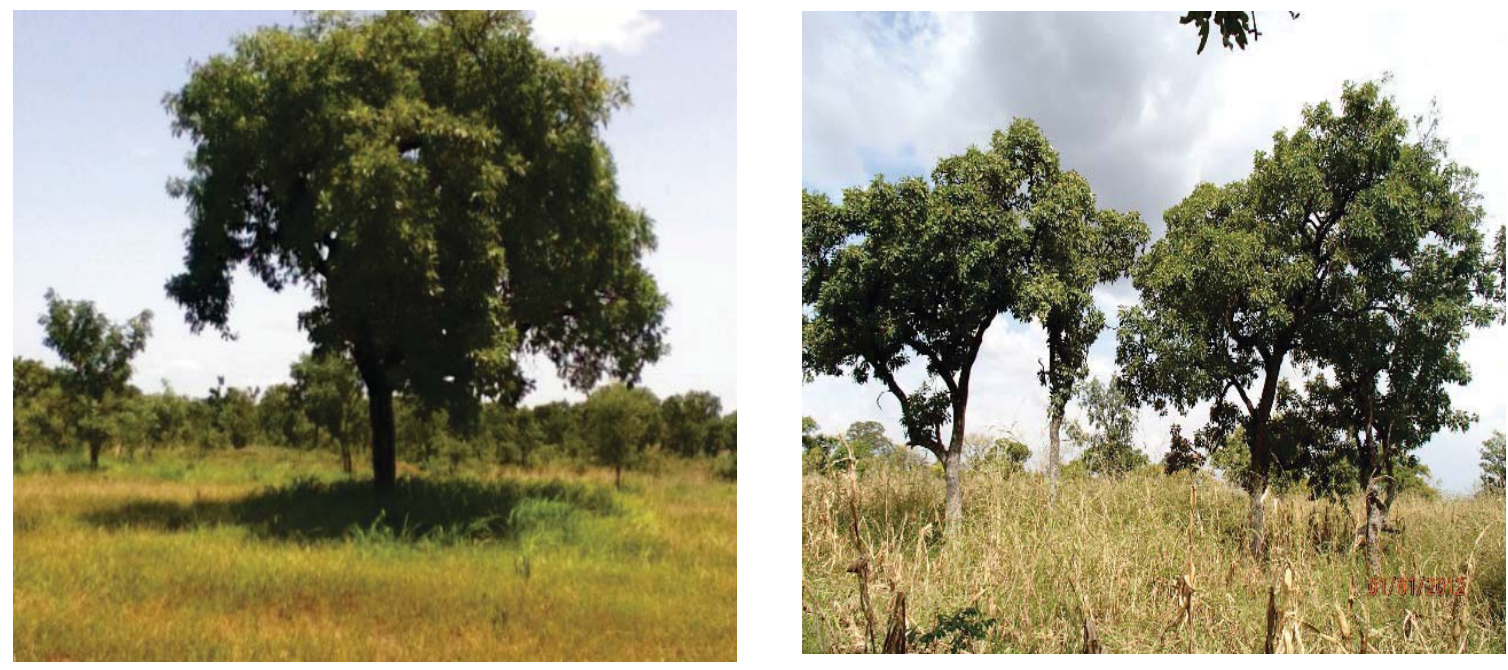

Figure 21: (A) Example of single tree on farm. (B) Example of clump tree on farm. 


\section{Vitellaria paradoxa}

$V$. paradoxa of the Sapotaceae family in the sub tribe Mimusopinae (Henry et al., 1983 ) is native to Africa and is commonly found at altitudes of $100-1200$ meters, and range within the dry savannah zones east of Senegal to northwest Uganda (Hall, 1996). $V$. paradoxa is a shade intolerant tree that thrives in areas where the average rainfall is 600 $1400 \mathrm{~mm}$, but avoids areas where water accumulates for extended periods of time. It forms an extensive root system in order to survive long dry seasons (Orwa, 2009). The species prefers dry and sandy clay soils and avoids alluvial hollows (Orwa, 2009; Boffa, 1995).

$V$. paradoxa is a medium sized tree which grows to a height of $15-20 \mathrm{~m}$. It is characterized by having a short bole with varying crown sizes. Its bark is rough with deep fissures in the shape of rectangles that are up to $4 \mathrm{~mm}$ thick. The blaze of the bark is red and secretes white latex when the bark, branches, and leaves have been cut (Figure 22A). Its leaves are green and grow off a small twig $5 \mathrm{~cm}$ long where a cluster of 20 - 30 leaves will form (Hall, 1996) (Figure 22B). Leaves are oblong and measure $27 \mathrm{~cm}$ long and 7 cm wide with wavy leaf margins (Hall, 1996). Flowers are white and form a fascicle that is $5-7.5 \mathrm{~cm}$ long that contain $30-40$ flowers (Hall, 1996). The fruit of $V$. paradoxa is subglobose and is 3-4 cm wide with a greenish yellow palpable pericarp that is $4-8 \mathrm{~mm}$ thick (Hall, 1996). The fruit contains a brown nut that is $2.8 \mathrm{~cm}$ wide and $3.5 \mathrm{~cm}$ in diameter. The seeds are recalcitrant and contain a kernel (Hall, 1996). V. paradoxa is propagated through self-pollination as well as cross-pollination. Because the fruit is edible, seeds are often dispersed by animals as well as humans (Orwa, 2009). 

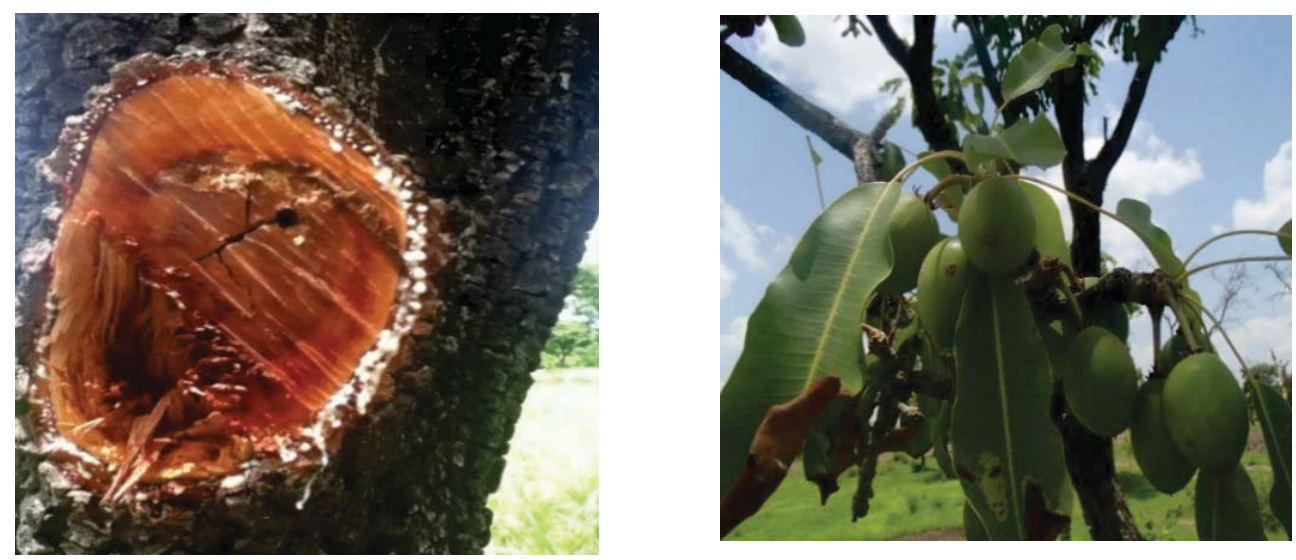

Figure 22: (A) Pruned V. paradoxa showing red blaze and latex secretions. (B) Leaves and fruit of V. paradoxa.

\section{Site preparation}

All farms were plowed using a mechanical plow prior to harvesting. Farmers

planted maize in June of 2014 using local planting techniques. Maize was sown using an $80 \mathrm{~cm} \times 25 \mathrm{~cm}$ spacing method, and herbicide was applied the day after planting using a backpack pump sprayer. Based on farmer preference and availability, farms were weeded 2 - 4 weeks after planting (Table 2). Chemical fertilizer was applied on all farms (Table 2), however during the farming season of 2014, an increase in fertilizer costs and no available subsidy made it difficult for farmers to afford fertilizer and quality seeds. Many farmers used fertilizer from the prior season, or seeds that were more affordable

Table 2: Site preparation of each field including type of seed used and bags of seed per hectare, weeding after planting, ration of NPK and number of bags of ammonium sulfate used per hectare.

\begin{tabular}{|c|c|c|c|c|c|}
\hline Farm ID & $\begin{array}{c}\text { Seed (9- } \\
\text { kg)/ ha }\end{array}$ & $\begin{array}{c}\text { Weeding } \\
\text { (weeks after } \\
\text { planting) }\end{array}$ & NPK & $\begin{array}{c}\text { Bags (50- } \\
\mathbf{k g} / \mathbf{h a}\end{array}$ & $\begin{array}{c}\text { Bags of } \\
(\mathbf{N H}) \mathbf{S O}_{4} \\
\mathbf{( 5 0 - k g ) / h a}\end{array}$ \\
\hline MAH & Hybrid & 3 & $25-25-30$ & 4 & 2 \\
\hline ECO & Obaatampa & 3 & $15-15-15$ & 4 & 0 \\
\hline SED & PAN 53 & 4 & $25-25-30$ & 3 & 2 \\
\hline SAL & PAN 53 & 4 & $25-25-30$ & 3 & 2 \\
\hline MOS & Atubi & 1 & $15-15-15$ & 2 & 2 \\
\hline
\end{tabular}




\section{Experimental design}

Subplot locations of each tree was determined in order to measure the effects of full shade, partial shade, as well as full sun of all single and clumped trees. Subplots of single trees were measured at HRad (half the crown radius), Edge (crown radius), and Open (twice the crown diameter) (Figure 23). Each subplot was sampled in a north transect and a south transect of all single trees.

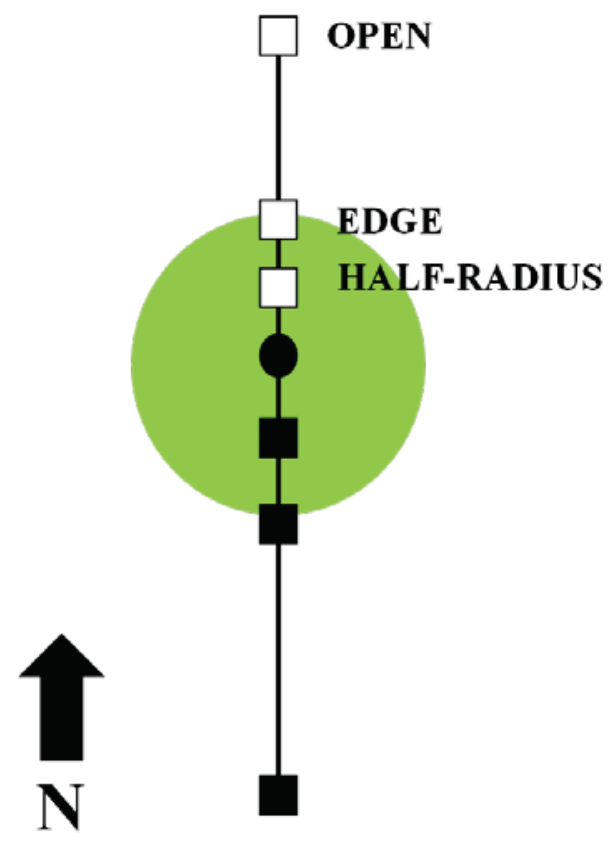

Figure 23: Subplot locations of single trees. Green circle represents the projected tree crown area, squares are subplots of maize sampling, and squares filled in black represent where soil moisture was taken as well. Black circle represents the tree stem.

Tree clumps were divided into triangles by creating transects between neighboring trees of the clump. Clumped tree subplots were measured at HRad (half the crown radius, Edge (crown radius), and Open, with additional subplots located at Mid (mid-distance between two neighboring trees), and Center (center between three trees) (Figure 24). The centroid of the triangle (center subplot) was determined by measuring a 
line from each tree to the location of Mid subplots of the opposite side. Where all lines crossed was the location of the Center subplot of three trees. Open field measurements were collected at the distance of twice the diameter perpendicular to the longest distance between two Mid trees in the clump (Total of subplot locations of clumped and single trees are recorded in Appendix A).

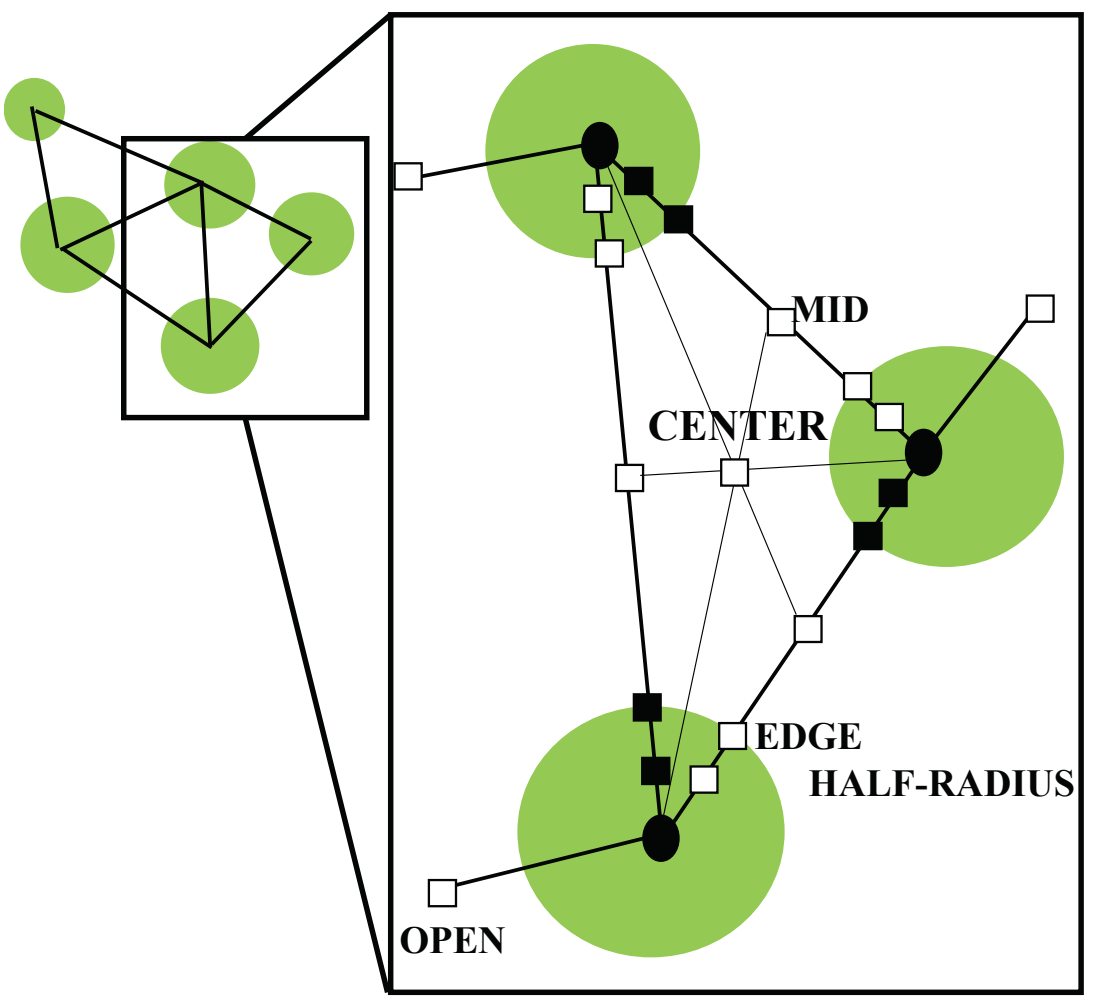

Figure 24: Example of triangles formed within clumped trees and associated maize sampling plots. Squares represent where HRad, Edge, Mid, Center, and Open plots are located within a triangle.

Maize vegetation and yield data collection began during harvesting season starting in October and ending in December of 2014. Diameter at breast height, crown diameter, crown projected area, total tree height, \% canopy cover and height to first branch were measured for each tree single and clumped tree. Total tree height was 
measured using a clinometer (SUUNTO, Vanta), and diameter at breast height $(1.3 \mathrm{~m})$ was measured using diameter tape (Forestry Suppliers, Jackson, MS, USA). Crown diameter was measured using an 8-point crown projection measurement.

\section{Soil moisture}

Soil samples were taken once during harvesting season. Samples were taken of singles trees as well as clumped trees using an auger at 0-20 cm (Figure 25A). For single trees, soil moisture samples were collected at HRad, Edge and Open subplots on the north transect (Figure 25B). Soil moisture samples were taken at all Mid, Center, and Open locations of clumped trees, and one sample each of HRad and Edge were taken for individual trees in each clump.

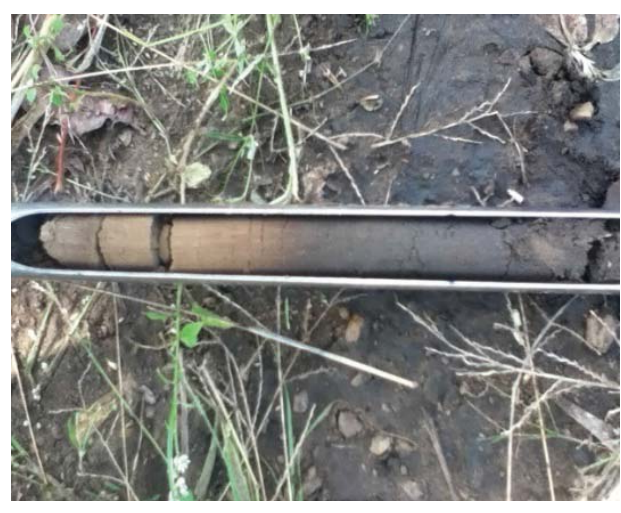

Figure 25: (A) $20 \mathrm{~cm}$ soil sample

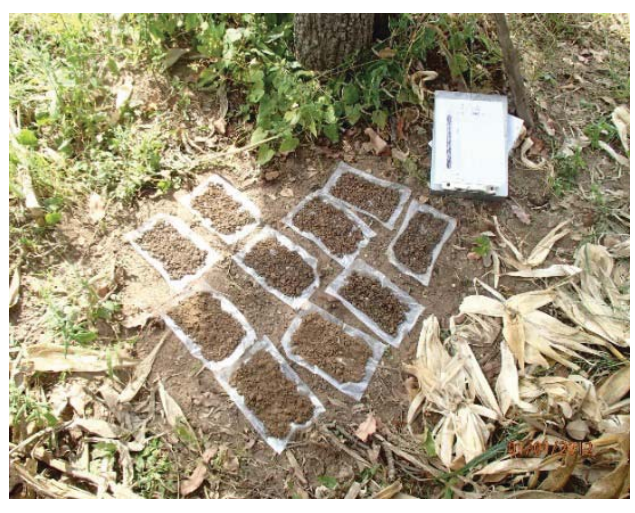

(B) Soil sample drying while collecting

Soil was weighed, air dried for three days, and weighed again to calculate volumentric soil moisture using a spring scale (Pesola AG, Baar, $\mathrm{CH}$ ) (Figure 26)

\section{Crop yield}

Maize crop yield was assessed by collecting maize from each $1 \mathrm{~m}^{2}$ subplot location during harvesting season (November). Total number of cobs of maize, total 
number of plants, mean stalk height $(\mathrm{cm})$, mean cob length $(\mathrm{cm})$, and total grain weight (g) in all subplot location of single and clumped trees were collected. Maize samples were collected, husked in the farm, and then taken to an enclosed area to dry in the sun for three days until they reached $13 \%$ moisture content. After drying, maize was threshed by hand and weighed using a spring scale (Pesola AG, Baar, $\mathrm{CH}$ ). After kernels were removed the empty cob length was measured. Yield was assessed as dry mass of grain per unit area of each subplot measured and then divided by the number of cobs to calculate yield per cob $(\mathrm{g})$.

\section{Light availability}

Percent canopy cover was measured using a spherical densiometer (Geographic Resource Solutions, Arcata, CA, USA). Measurements were taken at each of the four corners of $1 \mathrm{~m}^{2}$ subplots in all locations of individual trees as well as clumped trees.

\section{Interviews}

A range of adult men and women farmers between the ages of 18 and 60 were interviewed on their preferences for maintaining trees on their farms (Table 3).

Table 3: Total of males and females interviewed by age range

\begin{tabular}{ccc}
\hline Age Range & Male & Female \\
\hline $18-30$ & 3 & 2 \\
$30-40$ & 6 & 6 \\
$40-50$ & 9 & 5 \\
$50-60$ & 6 & 5 \\
\hline Total & $\mathbf{2 4}$ & $\mathbf{1 8}$ \\
\hline
\end{tabular}

Purposive sampling technique was used to select farmers for interviews. Village population size was 2, 214 located within the Wa East District of the Upper West Region. The ratio of men to women is $1: 1$ with $49 \%$ of the population between ages $15-60$ 
(GLSS, 2014). Interviews were conducted as semi-structured conversations, assisted by a local translator. Institutional Review Board (IRB) authorization was achieved and questionnaire approval by Michigan Technological University Institutional review board (approval \# M1199) was obtained. An oral consent statement was read to each farmer and agreed upon before every interview (Appendix B). Interview questions are listed below (All responses of males and females are listed in Appendix C):

\section{Social Questions}

1.) Age?

2.) Married?

3.) Do you have any other forms of obtaining income other than farming?

4.) Were you born and raised in Bulenga? Has this made it difficult to own land and carry out your farming practices?

\section{Tree Management Questions}

1.) Do men or women tend to keep more shea trees on their farms? Why?

2.) How do you prefer the trees to look on your farm? Scattered or clumped together?

3.) How do you remove trees on your farm to get the spacing that you want?

4.) Do you notice more or less fruit production of shea trees when trees are clumped together or when they are spread out?

5.) Do you notice a change in the amount of shea trees on the landscape from when you were a child?

6.) Do shea trees cause trouble for you when you are trying to farm? Do they create obstacles? 
7.) Do shea trees on your farm ever go through periods of low fruit production? Do you ever wonder why?

8.) How does bush burning affect your shea trees? Do you do anything to protect them?

9.) Have you ever planted shea?

\section{Farm Management Questions}

1. Are there differences in the way men and women manage their farming practices? What are some of the differences?

2. How many acres/crops/farm fields do you have?

3. Do you fallow your fields? How long?

4. Has this duration changed over the years?

5. Why do you choose to fallow your fields?

6. Do you pay/apply for these services on your farm? How much does it cost per acre of land? Who is in charge of these tasks?

- Fertilizer?

- Fertilizer application?

- Herbicide?

- Herbicide application?

- Harvesting (maize/shea)?

- Threshing?

- Transporting

- Planting (maize)?

- Grinding? 


\section{Data analysis}

A two-way analysis of variance (ANOVA) was used to investigate effects of both measurement location and tree distribution (single vs. clumped) on yield, growth, percent cover and percent soil moisture. Measurement locations that were considered in both single and clumped tree subplots were half radius, edge and open. A separate one-way ANOVA was used to compare the impacts of half radius, edge, center, mid and open measurement location of clumped trees. Fisher's least significant difference mean separation procedures were used to test differences between measurement locations $($ alpha $=0.05)$ and also to test differences between single vs. clumped tree distributions $(\mathrm{alpha}=0.1$ due to low statistical power for single tree measurements). Procedures were performed using SAS version 9.2 statistical software (SAS Institute Inc., Cary, NC, USA). Correlations between percent canopy cover, soil moisture and maize yield and growth variables were assessed using linear regression analysis in Microsoft Excel (Microsoft office professional plus 2013, Redmond, WA, USA).

Interviews were analyzed through a coding approach as a means of categorizing major themes that were determined by the different genders and age groups of farmers (Bernard, 1995). 


\section{CHAPTER 6: RESULTS}

\section{Single and clumped tree measurements}

Overall size and structure of individual trees for both single and clumped tree plots were similar. Mean height to lowest branch of all trees in clumps was $2.2 \mathrm{~m}$, and 2.9 $\mathrm{m}$ for all single trees. For clumped trees mean diameter at breast height (DBH) was 86.7 $\mathrm{cm}$, mean tree height was $9.8 \mathrm{~m}$ and mean crown diameter $7.2 \mathrm{~m}$. For single trees mean DBH was $80.8 \mathrm{~cm}$, mean tree height was $9.5 \mathrm{~m}$ and mean crown diameter was $7.2 \mathrm{~m}$ (Table 4). For single trees, mean distances from stems to subplots at HRad, Edge and Open locations were $1.7 \mathrm{~m}, 3.4 \mathrm{~m}$ and $14 \mathrm{~m}$, respectively. Mean distance of subplots from each tree in the clumps were 1.6 m, $3.2 \mathrm{~m}$ and $12.9 \mathrm{~m}$ for HRad, Edge and Open. Mean distance of all Mid (halfway between two trees) distances in a clump was $6.6 \mathrm{~m}$, and mean distance of all Center (between three trees) distances was $3.2 \mathrm{~m}$ (Table 4).

\section{Effects of single and clumped trees on light availability and soil moisture}

Mean percent canopy cover decreased steeply as measurement locations moved farther from under the canopies of $V$. paradoxa for both clumped and single trees (Figure 26A). Percent canopy cover showed a significant difference between HRad, Edge and Open measurement locations of single trees. Clumped trees showed a significant difference between, but showed no significant difference between the interaction of clumped and single trees at. Mean percent moisture decreased with distance from tree stems of clumped trees, while mean soil percent moisture was higher at locations farther from the stems of single trees (Figure 26B). Mean percent soil moisture under clumps was 50\% higher at HRad location compared to single trees, and showed a significant 
difference at the HRad measurement location between clumped and single trees $(\mathrm{P}=<$ 0.07) (Figure 26B).

\section{Effects of clumped vs. single trees on vegetative growth and yield of maize}

Cob length and stalk height shows little variability between clumped and single trees (Figure 27A, 27B). Spatial distribution of $V$. paradoxa had a much larger effect on grain yield of maize than cob length or stalk height, especially under the canopy (HRad) and at the edge of tree canopies (Figure 27C, 27D). Mean grain yield per cob and per plot increased as measurement locations moved farther from single trees. Within clumps, HRad and Edge locations showed higher yield per area and per cob compared to locations outside of tree canopies (Mid, Center, Open). The highest yield overall was at the Edge location of clumped trees, and Center location showed higher grain yield than Open and Mid locations within clumps. Clumped trees showed higher overall mean grain yield per area and per cob when compared to single trees, but Open locations were no different for clumps vs. single tree plots.

\section{Percent cover effect on maize}

Light availability did not explain the variation in grain yield, but did affect vegetative growth of maize (Figure 28). Both cob length $(\mathrm{P}<0.001$; Figure $28 \mathrm{~A})$, and maize stalk height $(\mathrm{P}=<0.03$; Figure $28 \mathrm{~B})$ increased with greater light availability (i.e., decreased with increasing canopy cover $)$. Grain yield per plot area $(\mathrm{P}=0.48$; Figure $28 \mathrm{C})$ and grain yield per cob length $(\mathrm{P}=0.24$; Figure $28 \mathrm{D})$ showed no relationship with percent canopy cover. 


\section{Percent moisture effect on maize}

Percent moisture showed the opposite trend to light availability, where it did not explain the variability of cob length or maize stalk height associated with single and clumped trees, but did show an effect on grain yield (Figure 29 B). Cob length showed no relationship with percent soil moisture $(\mathrm{P}=0.54$; Figure $29 \mathrm{~A})$, or with maize stalk height $(\mathrm{P}=0.19$; Figure 29B $)$. Grain yield per plot $(\mathrm{P}=<0.0001)$ and grain yield per $\operatorname{cob}(\mathrm{P}=<$ 0.001) both steeply increased with increasing soil moisture (Figure $29 \mathrm{C}$ and D).

\section{Social effects on agroforestry parklands}

Advancements in farming practices within rural Ghana is motivating farmers to modify traditional farming systems to more intensive cultivation practices, which could result in large scale land cover changes in agroforestry parklands of the Upper West Region of Ghana. Whether or not farmers adopt different land-use strategies often depends on the accessibility of resources to the farmer. Factors that can aid in the commercialization of agriculture can include: accessibility to roads and markets, clustering of land settlements, changes in government policy as well as limitations of customary rule such as issues concerning land tenure. However, shifting perceptions to more commercialized-based farming can have detrimental effects on the land through intensive cultivation, resulting in the decline of natural on-farm resources, such as shea. These impacts can reduce resources that are available to the marginalized groups of people, especially women, who depend on these resources in their daily lives. Even though farmers understand the importance of on-farm resources such as shea, they may not know the full extent of the impact that changing farming practices can have on the sustainability of such resources. 
In Bulenga, land is acquired through kinship relationships or through agreements made with the village landlord. Most often, land is passed down through patrilineal land tenure, where males of the family inherit land from their fathers. This land always remains within the family and cannot be preempted. Customary rule makes it difficult for women to own and manage land. Although, in some cases women have inherited land through their fathers if not married, or if a husband dies or abandons the family, she is able to continue farming the land. Most commonly, women in Bulenga obtain rights to land through usufruct rights of her husband's land. If residents of the area want to acquire more land, or if people who are not native to the village want to farm in the area, they must request land from the landlord. The landlord's position is a customary institution, and his authority is determined through the parentage of the first African settler in this area, therefore he has control over the land. The landlord is responsible for selecting the chief whose jurisdiction includes all aspect of village's social and political rule except for the land itself. Because land is plentiful, land is free, but an offering is given in the form of kola nuts out of respect. In some cases, money is given in exchange for land based on the landlord's discretion. However, agreements of land-use rights can be undermined. Farmers show ownership of land by clearing or maintaining the land. If a farmer does not return to his field for an extended period of time, there is a chance they can lose claim over the land.

The management of farmland in Bulenga is primarily used to benefit the needs of the family, therefore farming activities are carried out through family cooperation. Onfarm resources, such as non-timber products, can be utilized by members of the family lineage, but male farmers decide what crops are grown, which farm resources are used, 
and how income generated from farming activities is spent. Although males have the final authority over the farm, they will take into consideration the specific needs of family members. For example, males will consult with their wives about which on-farm resources she is utilizing before carrying out management plans. Men and women often farm together, but recently women are deciding to manage their own portion of land. Therefore, husbands will usually allocate one to two acres to their wives, who can decide what crops are grown. She is in charge of providing any inputs that are needed in farming the land. Women often use resources that they gain from farming to carry out responsibilities that are required for the household. For example, women will cultivate crops that are used in meal preparation, and use any additional income generated for children's school fees. She is in charge of selling her own crops or processing them in the sale of food stuffs. However, women are obligated to work on their husband's land before their own portion of the land. This can be problematic for women because it can decrease the productivity of their own farms.

Crops grown are similar between men and women, however other on-farm resources that are utilized by men and women differ. Cash crops are seen as the most opportunistic by men and women in terms of maintaining the livelihood of their family. Men are more often interested in the growth of cash crop; however if resources are available, women will also cultivate cash crops. Farmer interviews revealed that male and female farmers devoted more total acreage to the growth of maize, a cash and staple crop, than any other crop. Maize was grown on a total of 39 acres of all farmers interviewed (Figure 30). However, maize requires high amounts of farming inputs. Women often grow crops that don't require many inputs, such as soy bean. Also, female farmers will 
cultivate crops that can form ingredients for meal preparation or can be processed and sold as secondary items, such as shea butter processed from the shea nut. However, farmers put more importance into the production of cash and staple crops compared to other on farm resources such as shea. Since shea grows naturally, farmers do not believe that it is considered a crop. However, this idea is changing now that farmers are realized that shea has a high market value.

Farm responsibilities are determined by specific gender roles which are based on family and social hierarchies. Chain of command is determined by gender, age and marriage. Adult men and young adult men are responsible for clearing and weeding the land, operating farm mechanization such as plows and threshers, applying herbicide with a backpack pump sprayer, and determining spacing of crops through the placement of seed beds. Women are often excluded from these activities due to specific gender roles that have been adopted over time as well as gender discrimination that women are not smart enough to perform these tasks. Women and young adult women are often delegated to low intensity responsibilities such as sowing, harvesting, and preparing meals and providing water to family members and laborers working on the field. Some roles are determined by which crops are grown. This is often seen with threshing activities. For example, threshing groundnuts is a low intensity activity and a communal activity for women to engage in, whereas threshing soy bean is a high intensity activity where dried bean pods need to be beaten with a stick. Women rely heavily on free male labor within her family, otherwise she will have to perform male roles herself or pay laborers. If she cannot afford certain services, she will not apply them on her field at all. It is often difficult for women and men to cross-over into roles that are to be performed by the 
opposite sex due to social pressure. If a woman engages in work that was to be performed by her husband, she can publically shame him by allowing people to think she is trying to out-compete her husband, and he may be seen as weak. Children are also involved in these practices, but mostly to learn how to farm land to provide for their family as adults.

Farming in Bulenga is largely heterogeneous as explained by differing resources available to farmers, such as access to land, labor, and credit. Bulenga is located on a major road to Wa, the capital city of the Upper West Region, which allows farmers to have greater access to the larger markets of Wa. Because of the locality of Bulenga, large-scale intensive commercial cultivation is much more accessible to farmers. Our interviews revealed that many farmers of Bulenga who once farmed for subsistence are now doing so for profit. Therefore, market-based incentives could prompt agricultural development within this area. Locality could also be a contributing factor to the introduction of mechanization and labor-saving technologies which reinforce farmers to continuously crop fields. Interviewed farmers state that farm land is plentiful in this area and that land for farming is easily acquired. Modern technology could make expansion of farm-size more likely. However, a large portion of farmers within Bulenga are currently small-scale farmers. This transition is creating large disparities for farmers, making it difficult for small-scale farmers to compete. Large government deficit and public sector borrowing is intensifying the availability of credit, which largely affects farmers who have limited assets. Therefore, farmers are often limited by capital which includes income to hire labor. This is primarily true for small-scale farmers, especially women who are often more limited to resources. Interviews revealed that male and female farmers realize women are at a disadvantage in terms of farming. Within the community, 
women will form small cooperatives, such as village saving and loans groups as well as create groups to take loans from microfinance companies (who are more likely to give loans to large groups and not individuals) to gain initial capital for farming. However, the constraints that men perceived women had often differed from the actual constraints that women listed during our interviews. For example, $58 \%$ of women stated that capital was their largest constraint, whereas $56 \%$ of men believed that labor were women's highest constraint (Figure 31). Clearing land is highly labor-intensive, and men often believe that women are not physically able to cultivate land. However, women will exchange work on each other's farms to reduce the amount of labor needed. Labor can easily be hired which leads women to realize that their largest constraint is capital. Because it is difficult for women to acquire the initial capital to clear their fields, they will rotate their land with nitrogen-fixing crops, such as legumes, making fertilizer less necessary. Women within this interview study were shown to fallow their fields an average of one year, while men fallowed their fields an average of 2.5 years.

Maintaining larger fields is highly labor intensive, and farmers are adopting the use of more inputs. Therefore, mechanized farming practices such as tractor and processing machinery as well as chemical inputs such as fertilizers and high-yielding seed varieties are being used more frequently in order to in to maintain high production. These added inputs are attractive to farmers because they appear to be more productive compared to small-scale practices. However, improved farming techniques are slowly degrading available arable land and farm resources due to the nature of continuous cropping. High tree density can create obstacles to mechanization. Male farmers will decide to remove trees on the farm to reduce tree-crop competition. This often includes 
removing trees that do not provide any benefit, while allowing beneficial trees, such as shea, to remain. Alternatively, they will manipulate shea trees on their farms to reduce competition. This includes pruning low hanging branches to reduce light competition with crops and allow tractors to maneuver in the field. However, farmers who are transitioning to larger scale farming practices are more likely to remove more shea in order to dedicate more land area to cash crops, whereas small-scale farmers rely heavily on the income generated by shea trees and are less likely to remove shea. Because women are often small-scale farmers, collecting and processing shea nut is mainly carried out by women. Interviewees stated that women primarily collect shea. Socially, this is a women's defined role, therefore men are not often seen collecting shea. Shea trees provide a large economic benefit to women, so they increase shea density on the farm. In this study, $61 \%$ of both male and female farmers stated that women have more of a preference for maintaining a higher density of shea on the total farm area, including hers and her husband's farm, compared to men. Because farmland is to benefit the needs of the family, male farmers will consult their wives on which trees to remove. However, both men and women believe that trees compete highly for resources with crops and adjacent shea trees. Therefore, shea trees are highly manipulated into scattered distributions, rather than clumps. Eighty percent of male and female farmers in this study reported that they would prefer shea trees to be more scattered. The remaining twenty percent said they have no preference, that the nature of tree growth determines distribution. Farmers stated that when trees are scattered, shea produce more fruit as well as reduce competition with crops. Secondarily, scattered trees allow space for the tractor to plow the field, and reduce air moisture for pest control. Farmers do not use specific 
spacing techniques; however, they determine management plans through inherited knowledge from older generations. Therefore, management strategies vary among people within this area based on farming preferences. Management plans that farmers discussed included: removing two trees if four are present, or removing one tree if three are present. Although shea trees are being removed to allow crops to grow, $67 \%$ of women interviewed believed that shea is increasing because shea nut collection is providing more market benefit. However, male responses differed where $53 \%$ of men also believed that shea is increasing due to increasing market benefit, but $47 \%$ believed that shea is disappearing due to larger farm size, commercialized farming, and increased thinning. Although more farmers believed that shea is regenerating, many farmers stated that they will protect trees from seasonal bush burning. Bush burning caused tree to have low fruit production, so farmers will weed around trees and create fire belts around their farm to prevent fire from entering their fields. They stated that this protects flowers from being destroyed by fire to increase yield. 


\section{CHAPTER 7: DISCUSSION}

\section{Effects of clump vs. single trees on growth and yield}

As expected, both grain yield and vegetative growth of maize increased with increasing distance from stems of single trees, likely due to increasing water availability. A similar study that focused on single tree influences on crops found that millet yield increased with increasing distance from Parkia biglabosa, but as a result of increasing light availability (Kater, 1992). Under clumped trees of our study, vegetative growth of maize increased in with increasing distance from stems, however contrary to expectation, grain yield was significantly higher at the canopy edge compared to open field locations. This was similar to results reported by Boffa et al. (1999), where sorghum yields were greater at locations under the edges of tree crowns of $V$. paradoxa than at positions between two trees. This suggests that tree density had an effect on creating microclimates at the canopy edge and the area between multiple tree canopies.

Contrary to the assumptions of local farmers and our own hypothesis, maize yield was found to be significantly higher under clumped trees compared to single trees. Stem density of agroforestry trees has an apparent effect on crops thought to be attributed to intercepting light under canopies, resulting in lower sub-canopy temperatures and reduced evapotranspiration (Vetaas, 1992). High temperatures can reduce the rate of development of crops, especially in water-stressed environments that are often found in semi-arid West Africa (Jonsson, 1999). Higher tree densities could create favorable temperatures for co-occurring crops, while still allowing full sunlight that plants need in

order to carry out functions of photosynthesis (Vetaas, 1992). Higher topsoil moisture has 
been recorded in Kenya at sites where trees were incorporated into cropping systems compared to treeless sites (Jackson, 1999). Sparse shade cast by individually, scattered tree distributions was not able to off-set increased evaporation during intense sun (Shreve 1931) and during high winds (Kainkwa, 1994).

Tree canopy structure and tree density may have impacted the redistribution of rainfall. Rainfall is redistributed by trees to the ground by stem-flow and through-fall, and to the atmosphere by evaporation of intercepted rain (Vetaas, 1992). However, this is proportional to the durations and seasonality of rain events. Surface soil moisture was reduced directly under the canopies of single tree compared to open locations. Trees that are leafless during rainy seasons cause little rainfall interception. In Burkina Faso, rainfall was uniform under and on the edge of F.albida during the rainy season (Rhodes, 1995). Stem-flow and canopy interception can irregularly distribute water which could have caused lower soil moisture under single trees. Conversely, soil moisture was higher under clumped trees which could be a result of reduced evaporation and plant transpiration due to lower temperatures that are associated with increased tree density (Boffa, 1999).

In some instances, areas under the tree were not properly tilled for farming. Farmers till fields to loosen compacted soil which allows for higher water filtration within the soil layers (Olanrewaju, 2015). Trees are often seen as obstacles to farmers for this reason. The areas under trees are difficult for tractors to plow due to the shallow roots and low hanging branches of shea, therefore the area under the tree is often not plowed, or no seed bed is prepared. This creates different rooting environments for crops and has the ability to change the soil surface, which could increase run-off (Glover et al., 
1962), therefore limiting the ability of crops to access enough water for optimal growth and yield.

Yet, in water-stressed environments, improved physical soil conditions near rooting zones of woody plants can contribute little to crop performance due to high competition between trees and crops (Rao, 1998). In dry savanna ecosystems, herbaceous understory plants minimize competition for water with trees by occupying areas outside the influence of their rooting zones (Vetaas, 1992). This could explain why decreased yield was found under single trees. Increased competition for water was higher in single trees due to an increase in water evaporation of wind. Clumped trees could decrease through wind breaks through higher tree density. Soil moisture associated with single trees could be reduced because single trees could be experiencing higher rates of wind. More wind turbulence could result in a higher evaporative demand on transpiration; therefore more water will be taken up by shea leaving less soil moisture for crops overall.

\section{Effects of light and soil moisture on growth and yield}

It was found that vegetative growth of maize, including stalk height and cob length, correlated with light availability regardless of its association with clumped or single trees. In semi-arid farming systems, biomass production can be suppressed under tree canopies versus in the open due to increased light competition (Boffa, 1999). In a similar study, Kessler (1992) found that sunlight intensity was reduced up to $45 \%$ under shea trees, which resulted in decreased sorghum production. However, vegetation growth only slightly increased from under tree canopies to open location of both single and clumped trees. Reduced irradiance hitting the ground is also affected by tree size. Intercepted radiation decreased up to $75 \%$ of V.paradoxa when crown diameters were 
reduced by $2 \mathrm{~m}$ (Jonsson, 1995), therefore farmers often prune trees to mitigate the adverse effects that shading can have on crops. Because farmers prune single and clumped trees, they could be reducing the effects that increased shading has on competition for light.

Higher concentration of soil moisture under tree canopies compared to open locations is a common pattern in savanna parkland systems (Boffa, 1999). This is important in areas where competition for water is high. In our study, maize grain yield was found to be correlated with water availability of clumped and single trees. This showed that light was not the primary determining factor in maize yield productivity. Although, past studies have found that grain yield is determined by intercepted light (Boffa, 2000; Kessler 1992), these findings were based on the influences of single trees, and between two trees. As the number of stems increases, shading caused by changing directions of the sun is more likely to occur. However, cardinal direction does not often result in significant variation in productivity of agricultural crops (Boffa, 1999).

Conversely, if shading is uniform based on cardinal direction, light availability is equally distributed with shade. This indicates that light availability is similar in clumped and single trees, which suggests that other factors could be involved in improving yield other than light. Trees can improve yield productivity as greater quantities of water are able to be used by crops since less water is being lost by evaporation under their crowns (Ong, 2007).

Also, maize plants possess characteristics that act as catchments which distribute water at the base of the stalk. (Glover et al., 1962). This is important during small rain events when crown interception is more likely. The ability for trees to lower sub-canopy 
temperature could allow crops to utilize more water, since less will be lost from evaporation. Therefore, maintaining tree distributions that are able to maintain optimal growing temperatures could assist in improving crop performance in the arid tropics.

\section{Decision making with respect to maintenance and spacing of agroforestry parklands}

Transitioning farming systems has been a widely encountered trend within many African countries as a process of economic development and population pressure (Conley 2001). Population increase is considered to be a fundamental driver of agricultural transformation and advancement (Boserup 1965); which could be a cause for the adoption of more intensive cropping systems and modern technologies that were observed in Bulenga. Yet, progressive changes with land-use also include a combination of external impacts such as demographic changes, government policies, and accessibility to market systems which may exclude population growth as a determining factor of intensified cropping systems of this study area. In the Northern region of Ghana (Tamale), it was found that population growth had little effect on land-use change, where accessibility played a larger role in contributing to increased commercialization of farming practices (Braimoh 2005). Rather, in areas of low population, expansion is more likely to be encountered (Braimoh 2005). Furthermore, farmers in Bulenga stated that land was plentiful and there were no limitations on owning land, which is consistent with the characterization that Africa is typically land abundant (Jayne 2014). However, farmers are adopting intensive cultivation practices that you would expect in areas of high populations (Boserup 1965).

It is possible that the potential for expanding to arable land could be underestimated by farmers in the area. Chamberlain et al. (2014) estimated that only 22- 
$24 \%$ of the land in Ghana is actually economically viable for cropping expansion (as opposed to $68 \%$ in Zambia). Misrepresentation could be mediated by a combination of social demographic factors that influence human-environmental relations. Clustering is a commonly observed in many rural settlements of Africa, which could be aided by many different factors such as areas of production potential, environmental condition, or access (Maro and Mlay 1982). In areas of Northern Ghana, Braimoh (2014) found that land clearing for cultivation increased in areas near markets and roads as an incentive to easily sell agricultural produce. This could cause population density in these areas to increase, even if overall population remained constant. Therefore, location of farmland is important, where land may be available but not advantageously located. The further that land is located from population centers, the higher transportation costs can become for the farmer. As a result, farmers could show higher competition for land in areas near roads and markets causing location of farmland to be more of a constraint than the availability of land.

Viable land could be further reduced by the intrinsic value of land based on environmental factors. This includes soil fertility, soil type, and advantageous microenvironmental conditions. However, the difficulty of small-scale farmers to move to fertile farmland that is farther from roads may be a large economic trade-off. As a response, farmers are continuously cropping farm fields, shortening fallow systems and increasing fertilizer use and inputs. Nutrient depletion and land degradation can result from intensive cultivation of these areas (Jayne 2014).

This could also be causing a large dichotomy between farmers within this area, where larger scale farmers are able to expand in farm size to more fertile lands where 
small holder farmers, who are the majority, reduce farm size and continuously crop fields (Jayne 2014). This also has further implications on gendered farming. Women often have limited land rights and are less likely to gain independent control over land, and as competition for land is increasing, women are being further marginalized from land use rights (Abbas 2007). Because customary practices that grant greater control over land to men, women also have little authority over on-farm decision making of family farms (Kiptot, 2012). Male and female farmers can largely differ with respect to management of agricultural lands due to gender-based needs such as divisions of the household responsibilities, which extend to household agriculture. Male interests in intensifying farming systems that favor the growth of commercialized crops limit women's ability to manage for other on-farm resources that are important to their daily lives (Chikoko, 2002). Women are often associated with collecting shea and benefit financially by making shea butter from the collected shea nuts. In some cases women can contribute up to $20 \%$ of household income from shea nut products (Pouliot, 2012). Land-use transition into intensive cultivation results in nutrient depletion and land degradation which can ultimately impact shea. Shea nut forests that were traditionally utilized by women are being converted into farmland that is no longer available for women (Duncan and Brants 2004)). Furthermore, croplands where shea is utilized are being degraded. Traditional bush-fallow systems that allow long periods of fallow that improve soil fertility and favor tree regeneration are possibly being reduced by intensive cultivation that is observed in this area.

Shea trees are often seen as obstacles on intensively mechanized farmed fields, and are believed to interfere with crop growth. Management of shea trees is highly 
premeditated, especially in terms of reducing competition between trees and cash crops. On-farm tree removal is deliberate (Hansen 2012), and specific trees are chosen for removal without using technical spacing methods (Kelly, 2004). Farmers often choose wider spacing between trees to allow optimal growing space and reduce competition between crops and trees. However, the preference for sparse, scattered trees, could reduce the overall reserve of shea on cultivated fields (Elias, 2013)

In this study, both men and women, realized the constraints that women face, but differed in perceived versus actual constraints. In Bulenga, women stated that their largest constraint to farming was acquiring capital, whereas men believed women were limited primarily by the ability to do hard labor. The understanding that women are mostly constrained by labor is consistent with research (Abbas, 1997). However, this could be a perceived constraint, since many operations on women's farms may be left unfinished because their obligations are to work on their husband's farms. Women realize their actual constraint as capital, because men often have greater access to labor and financial resources, while women cannot afford investment in hired labor and instead need to rely on reciprocation of labor between kinship relations. Understanding actual constraints that women face may be difficult. Culturally, women are not permitted to talk openly in the presence of men unless specifically asked, and are often spoken for by their husbands. This may mask the actual constraints that women face, which could be important information for determining appropriate development programs.

Collection of non-timber products requires low skill and investment capital, therefore shea nut collection is attractive to the lowest income population, such as women. However, with increasing popularity for shea for cosmetics, the investment in 
collecting shea can prove to be more beneficial to women than farming in low income areas. Maize market prices in the three Northern Regions (among the poorest in Ghana) ranged from $42 \mathrm{GHc}$ - $64 \mathrm{GHc}(\$ 227-\$ 149)$ per $100 \mathrm{~kg}$ (MoFA, 2014). In Bulenga, at the beginning of the shea season $80-90 \mathrm{~kg}$ of raw shea nuts could be sold at $50 \mathrm{GHc}(\$ 178)$, and by the end of the season reached $100 \mathrm{GHc}(\$ 356)$. Because women are so highly invested in shea collection and production, development in this area favors women and has catered to their social structure (Pouliot, 2012). As women realize the benefit of collecting shea over farming, sustainable management practices of shea could result 


\section{CHAPTER 8: CONCLUSIONS AND CONSIDERATIONS}

I found maize production to be more limited by water availability than light availability, and also that maintaining trees in a clumped distribution was better for maize production than scattered distributions of individual trees in agroforestry parklands of Ghana. The presence and spatial orientation of V.paradoxa is vital to the continued production of agroforestry parklands within semi-arid areas where competition for water has increased. Soil moisture was higher under clumped trees than under single tree canopies. Higher tree densities could possibly create beneficial microclimates that help to reduce soil evaporation through reduced wind speed. Reduced transpiration could have resulted from cooler temperatures under tree canopies which could increase yield and growth compared to single trees. Maize height growth was correlated with light availability, while maize grain yield productivity correlated with water availability. We recommend the maintenance of tree clumps on farms to reduce the effects of water stress on co-occurring staple crops. Agricultural development programs should incorporate the importance of maintaining trees on the farm as an important role in successful commercialized farming practices.

Women make up 50\% of the agricultural work force in semi-arid West Africa, therefore women-based farming needs and constraints should be realized in order to maintain these systems. Conservation strategies that would improve shea sustainability should be incentivized through developed market systems in areas where technical farming knowledge is low. 


\section{CHAPTER 9: LIMITATIONS TO STUDY}

This research was carried out with in farm fields of rural Ghana. Variability in farm management differed between cropping fields as a result of resource availability to of the individual farmer. This included amount and concentration of chemical fertilizer, timing of weeding, and seed type used. Much of this is also explained by changes in government policy of this cropping year (2014). Fertilizer subsidies were removed, and fertilizer costs increased, which further reduced resources available to farmers. Many of the farms that were intended for sampling were not used because farmers planted different crops based on the changes in fertilizer use 


\section{REFERENCES}

Abbas J. D. (1997) Gender asymmetries in intra-household resource allocation in subSaharan Africa: some policy implications for land and labour productivity. In: Haddad L, Hoddinott J, Alderman H (eds) Intrahousehold resource allocation in developing countries: models, methods and policy. Johns Hopkins University Press for the International Food Policy Research Institute, Baltimore

Agusseau X., Nikiema P., Torquebiau E., (2006) Tree biodiversity, land dynamics and farmers' strategies on the agricultural frontier of southwestern Burkina Faso. Biodiversity andConservation. 15: 613-630

Al-Hassan, R. \& Poulton, C (2009) “Agriculture and Social Protection in Ghana”, (Working Paper No. SP01 - 2). Retrieved from Future Agricultures website: www.future-agricultures.org

Asse, R., Lassoie, J. P., (2011) Household decision-making in agroforestry parklands of Sudano-Sahelian Mali. Agroforestry Systems. 82: 247-261

Avery T.E., Burkhart H.E. Forest Measurements (4th ed.), McGraw Hill, New York (1994), p. 408

Battaglia, A.M., Mou, P., Palik, B., Mitchell J. R., (2002) The effect of spatially variable overstory on the understory light environment of an open-canopied longleaf pine forest. For. Res. 32: 1984-1991

Bayala, J., Teklehaimanot, Z., Ouedraogo, S. J., (2002) Millet production under pruned tree crowns in a parkland system in Burkina Faso. Agroforestry Systems. 54: 302 $-214$

Benneh, G., (1973) Small-Scale Farming Systems in Ghana. Journal of the International African Institute. 43(2): 134-146

Bernard, H. R., (1995) Research methods in anthropology. Walnut Creek, CA: AltaMira. 2000. Social research methods. Thousand Oaks, CA: Sage.

Boffa J-M. (1995). Productivity and management of agroforestry parklands in the Sudan zone of Burkina Faso, West Africa. Ph.D. thesis, Purdue University, West Lafayette, Indiana. $101 \mathrm{p}$.

Boffa J.M. (2000) West African agroforestry parklands: Keys to conservation and sustainable management. Unasylva 200. 51 
Braimoh A. K., Velk, P. L. G. (2005) Land-cover trajectories in Northern Ghana. Environmental Management. 36 (3): 356-373

Byakagaba P., Gerald E., Bosco B.L.O., Turnwebaze S.B., Mwavu E.N., (2011) Population structure and regeneration status of Vitellaria paradoxa (C.F.Gaertn.) under different land management regimes in Uganda. Agricultural Journal. 6(1): $14-22$

Campbell BM, Frost P, King JA, Mawanza M and Mhlanga L (1994) The influence of trees on soil fertility on two contrasting semi-arid soil types at Matapos, Zimbabwe.Agroforestry Systems 28: 159-172

Chamberlin J., Jayne T. S., Heady D., (2014) Scarcity amid Abundance? Reassessing the Potential for Cropland expansion in Africa. Food Policy 48 Http://dx.doi.org/10.1016/j.foodpol.2014.05.002.

Chikoko MG (2002) A comparative analysis of household owned woodlots and fuelwood sufficiency between female and male headed households: a pilot study in rural Malawi, Africa. PhD dissertation, Oregon State University, USA

CIA (Central Intelligence Agency), U.S. (2006). The World Factbook -Ghana. On line: https://www.cia.gov/library/publications/the-world-factbook/geos/gh.html. Site visited $1 / 27 / 2015$

CIA - The World Factbook [Internet]. (2012). Washington (DC): Central Intelligence Agency. The World Factbook: Ghana; [updated 2014 June 22, cited 2015 Jan 21]. Available from: https:/www.cia.gov/library/publications/theworldfactbook/geos/es.html

Cleaver, K.M., and Schreiber, G.A. (1994). Reversing the spiral. The population, agriculture and environmental nexus in sub-Saharan Africa. Washington, DC, USA: The World Bank.

Danquah, J.B. (1957). The historical significance of the Bond of 1844. Transactions of the Historical Society of Ghana. 3(1) pp. 3-29

Dumett, Raymond E. (1998). El Durado in West Africa: the Gold-Mining Frontier, African Labor, and Colonial Capitalism in the Gold Coast, 1875-1900. Ohio University Press, Athens. Pp.163

Duncan B. A., Brants C., (2004) Access to and Control Over Land From a Gender Perspective: a Study Conducted in the Volta Region of Ghana. Supported by the Food and Agriculture Organization of the United Stated (FAO) 
Elias, M. (2013) Influence of agroforestry Practices on the structure and spatiality of shea trees (Vitellaria paradoxa C.F. Gaertn.) in central -west Burkina Faso.

Agroforestry Systems. 87: 203-216

Fage, J.D., (1966). Ghana: A Historical Interpretation. The University of Wisconsin Press, Wisconsin. Pp.17-56

FAO (Food and Agriculture Organization). (2005). AQUASTAT website, Food and Agriculture Organization of the United Nations (FAO).

http://www.fao.org/nr/water/aquastat/countries_regions/ghana/index.stmWebsite accessed on: $2 / 5 / 2015$

FAO (Food and Agriculture Organization). (2001). Two Essays on Socio-economic Aspects of Soil Degradation, by L. Lipper \& D. Osgood. FAO Economic and Social Development Paper No. 149. Rome.

Gerken, A, J. Suglo \& M. Braun, (2001) Crop Protection Policy in Ghana. Integrated Crop Protection Project and Ministry of Agriculture, Pokoase, pp. 185.

Ghana Statistical Service (GSS) (2014) "Pattern and Trends of Poverty in Ghana 1991 2006", Ghana Statistical Service, Accra.

Glover, P. E., Glover, J., Gwynne, M. D. (1962) Light Rainfall and Plant Survival in E. Africa II. Dry Grassland Vegetation. Journal of Ecology. 50 (1) 199-206

Government of Ghana, Ghana Living Standards Survey (GLSS), Report of the Fifth Round (GLSS 5), Accra, Ghana, (1998).

Hansen, N. T., Raebild, A., Hansen, H. H. (2013) Management of trees in northern Ghana - when the approach of development organizations contradicts local practice.

2(4): 241-252

Hall JB et. al. 1996. Vitellaria paradoxa: a monograph. School of Agriculture and Forest Sciences, University of Wales, Bangor.

Hill, M. (2009). The Spread of Islam in West Africa: Containment, Mixing, and Reform from the Eighth to the Twentieth Century. SPICE digest. viewed at: http://spice.fsi.stanford.edu/sites/default/files/Islam.pdf. Site visited $1 / 27 / 2015$

ICRAF. (1993) Annual Report 1993. Nairobi Kenya. Pp. 208

Jackson N.A., Wallace J.S. (1999) Soil evaporation measurement in agroforestry system in Kenya. Agriculture and Forest Meteorology. 34 (3-4): 203-215 
Jayne T. S., Chamberlin J., Headey D. D. (2014) Land pressures, the evolution of farming systems, and development strategies in Africa: a synthesis. Food Policy. 48: 1-17

Johnsson, K. (1995) Agroforesty in dry savanna areas in Africa: Interaction between trees, soil, and crops. Ph. D. Dissertation. Umea, Sweden, Swedish University of Agricultural Sciences.

Jonsson (1999) Influence of Scattered nere and karate Trees on microclimate, soil fertility and millet yield in Burkina Faso. Experimental Agriculture 35:39-53

Kater LJM, Kante S and Budelman A (1992) Karité (Vitellaria paradoxa) and néré (Parkia biglobosa) associated with crops in South Mali. Agroforestry Systems 18: 89-105

Karbo, N., Agyare, W. A. (1998). Crop-livestock systems in northern Ghana. International Institute of Tropical Agriculture, Pp. 112-127

Kelly B. A., Bouvet JM., Picard N., (2004). Size class distribution and spatial pattern of Vitellaria paradoxia in relation to farmers' practices in Mali, Agroforestry Systems. 60:3-11

Kessler JJ (1992). The influence of karité (Vitellaria paradoxa) and néré (Parkia biglobosa) trees on sorghum production in Burkina Faso. Agroforestry Systems 17: $97-118$

Kiptot E., Franzel S. (2012) Gender and agroforestry in Africa: a review of women's Participation. Agroforest Syst. 84:35-58

Lentz, C. (2000). Colonial Constructions and African Initiatives: The History of Ethnicity in Northwestern Ghana. ETHNOS, pp. 107-136 (65:1)

Lovett P. N., Haq N (2000) Evidence for anthropic selection of the Sheanut tree (Vitellaria paradoxa). Agroforestry Systems. 48(3): 273-288

MoFA (Ministry of Food and Agriculture). (2013). Wa East. Online at: http://mofa.gov.gh/site/?page id=1683

MoFA (Ministry of Food and Agriculture) (2014) Weekly Market Prices (wholesale Values) of Food Commodities. Online at: http://mofa.gov.gh/site/?page id=8803

Moore S (2008) The role of Vitellaria paradoxa in poverty reduction and food security in the Upper East region of Ghana Earth \& Environment 3: 209-245 
Naylor, R.Ghana. Henderson: Stylus Publishing LLC. (2000).

Olanrewaju, R. M. Abubakar, A. S. (2015) Effect of Tillage Operations on Soil Moisture Contents in the Southern Guinea Savanna Ecological Zone of Nigeria. Journal of Water Resource and Protection. 7: 183-196

Ong CK, Leakey RR (1999) Why tree-crop interactions in agroforestry appear at odds with tree grass interactions in tropical savannahs. Agroforestry Systems 45:109129

Orwa, C, A. Mutua, Kindt R., Jamnadass R, S. Anthony. (2009) Agroforestry Database: A tree reference and selection guide version 4.0. Online at:

Poschen, P. (1986) An evaluation of the Acacia albida-based agroforestry practices in the Hararghe Highlands of Eastern Ethiopia. Agroforestry Systems, 4: 129-143.

Pouliot, M., (2012) Contribution of "Woman's Gold" to West Africa livelihoods: the case of shea (Vitellaria paradoxa) In Burkina Faso. Economic Botany. 669: 237-248. (http://www.worldagroforestry.org/sites/treedbs/treedatabases.asp

Pressland, A. J. (1976) Soil Moisture Redistribution as affected by Throughfall and Stemflow in an Arid Zone Shrub Community. Aust. J. Bot. 24: 641-649

Quisumbing A.R., Payongayong P., Aidoo J. B., Otsuka K., (2013) Women's Land Rights in the Transition to Individualized Ownership: Implications for TreeResource Management in Western Ghana. Economic Development and Cultural Change. 1: 157-182

Raebild, A., Hansen, U.B., Kambou, S. (2012) Regeneration of Vitellaria paradoxa and Parkia biglabosa in a Southern Burkina Faso. Agroforestry System. 85: 442-453

Rao, M. R., Nair, P. K. R., Ong, C. K. (1998) Biophysical interaction in tropical agroforestry systems. Agroforestry Systems. 38: 3-50

Rhoades, C. (1995) Seasonal pattern of nitrogen mineralization and soil moisture beneath Faidherbia albida (syn Acacia albida) in central Malawi. Agroforestry Systems. 29: $133-145$

Rhoades, C. C. (1997) Single-tree Influences on Soil Properties in Agroforestry: Lessons from Natural Forests and Savannah Ecosystems. Agroforestry Systems 35:71-94.

Sanou J., Bayala J., Teklehaimanot Z., Bazie P., (2011) Effect of shading by baobab 
(Adansonia digitata) and ne're' (Parkia biglobosa) on yields of millet (Pennisetum glaucum) and taro (Colocasia esculenta) in parkland systems in Burkina Faso, West Africa. Agroforestry Systems. 85:431-441

Shepperson, G. (1960). Pan-Africanism and "Pan-Africanism": Some Historical Notes $\backslash$ Phylon Vol. 23, No. 4 (4th Qtr. 1962), pp. 346-358

Shepherd, A., C. Jebuni, R. Al-Hassan, A. McKay, C. Poulton, A. Whitehead and J. Kydd (2005) "Economic Growth in Northern Ghana", Report prepared for DFID Ghana, Overseas Development Institute and Centre for Policy Analysis, London/Accra, October 2005.

Shreve, F. (1931) Physical Conditions in Sun and Shade. Ecology. 12(1): 96-104

Teklehaimanot, Z., (2004) Exploiting the potential of indigenous agroforestry trees: Parkia biglabosa and Vitellaria paradoxa in sub-Saharan Africa. Agroforestry Systems. 61: 207-220

Vetaas, O. R. (1992) Micro-site effects and shrubs in dry savannas. Journal of Vegetation Science. 3: 337-344

Wilks, I., (1989) Wa and the Wala: Islam and Polity in Northwestern Ghana. Cambridge: Cambridge University Press.

Yangmaadome, B.G., Faabelangne, D. B., Derbile, E. K., Hiemstra, W., Verschuuren, B., (2012) Sacred groves versus gold mines: biocultural community protocols in Ghana. Participatory Learning and Action, pp.65

Yidana, JA, Lovett PN (2004) Reinforcing sound management through trade: shea tree products in Africa. Unsylva 219, 55: 46-52 
TABLES AND FIGURES 
Table 4: Diameter at breast height, height, and crown diameter of single trees. Number of trees in clumps (n), mean $(\bar{x})$ and standard deviation (s) of diameter at breast height (Dbh), height and crown diameter of clumped trees in Bulenga, Upper West Region.

\begin{tabular}{|c|c|c|c|c|c|c|c|}
\hline $\begin{array}{l}\text { Single } \\
\text { Tree } \\
\end{array}$ & & \multicolumn{2}{|c|}{ Dbh (cm) } & \multicolumn{2}{|c|}{ Height(m) } & \multicolumn{2}{|c|}{$\begin{array}{c}\text { Crown Diameter } \\
\text { (cm) }\end{array}$} \\
\hline 1ST & & \multicolumn{2}{|c|}{88.6} & \multicolumn{2}{|c|}{13.7} & \multicolumn{2}{|c|}{8.2} \\
\hline 2ST & & \multicolumn{2}{|c|}{97.8} & \multicolumn{2}{|c|}{10.6} & \multicolumn{2}{|c|}{9.7} \\
\hline 3ST & & \multicolumn{2}{|c|}{45.2} & \multicolumn{2}{|c|}{8.8} & \multicolumn{2}{|c|}{4.8} \\
\hline $4 \mathrm{ST}$ & & \multicolumn{2}{|c|}{53.8} & \multicolumn{2}{|c|}{6.4} & \multicolumn{2}{|c|}{4.6} \\
\hline 5ST & & \multicolumn{2}{|c|}{118.4} & \multicolumn{2}{|c|}{7.9} & \multicolumn{2}{|c|}{8.9} \\
\hline Total & & \multicolumn{2}{|c|}{80.8} & \multicolumn{2}{|c|}{9.5} & \multicolumn{2}{|c|}{7.2} \\
\hline \multirow{2}{*}{$\begin{array}{l}\text { Tree } \\
\text { clump }\end{array}$} & \multirow[b]{2}{*}{$n$} & \multicolumn{2}{|c|}{ Dbh (cm) } & \multicolumn{2}{|c|}{ Height (m) } & \multicolumn{2}{|c|}{$\begin{array}{c}\text { Crown Diameter } \\
(\mathrm{cm})\end{array}$} \\
\hline & & $\bar{x}$ & $\mathbf{S}$ & $\bar{x}$ & $\mathbf{S}$ & $\bar{x}$ & $\mathbf{s}$ \\
\hline МАН & 9 & 81.8 & 6.7 & 10.4 & 0.7 & 6.1 & 0.3 \\
\hline ECO & 6 & 97.5 & 13.3 & 12.0 & 3.5 & 8.2 & 1.0 \\
\hline SED & 5 & 75.0 & 7.2 & 8.1 & 0.6 & 6.4 & 0.5 \\
\hline 1_SAL & 6 & 74.4 & 4.7 & 6.8 & 0.8 & 6.1 & 0.5 \\
\hline 2_SAL & 6 & 56.4 & 6.3 & 4.6 & 0.6 & 4.9 & 0.4 \\
\hline 1_MOS & 3 & 102.6 & 14.2 & 10.1 & 1.4 & 8.0 & 0.3 \\
\hline 2_MOS & 3 & 119.0 & 0.3 & 16.0 & 1.8 & 10.1 & 0.3 \\
\hline Total & 38 & 86.7 & & 9.7 & & 7.1 & \\
\hline
\end{tabular}



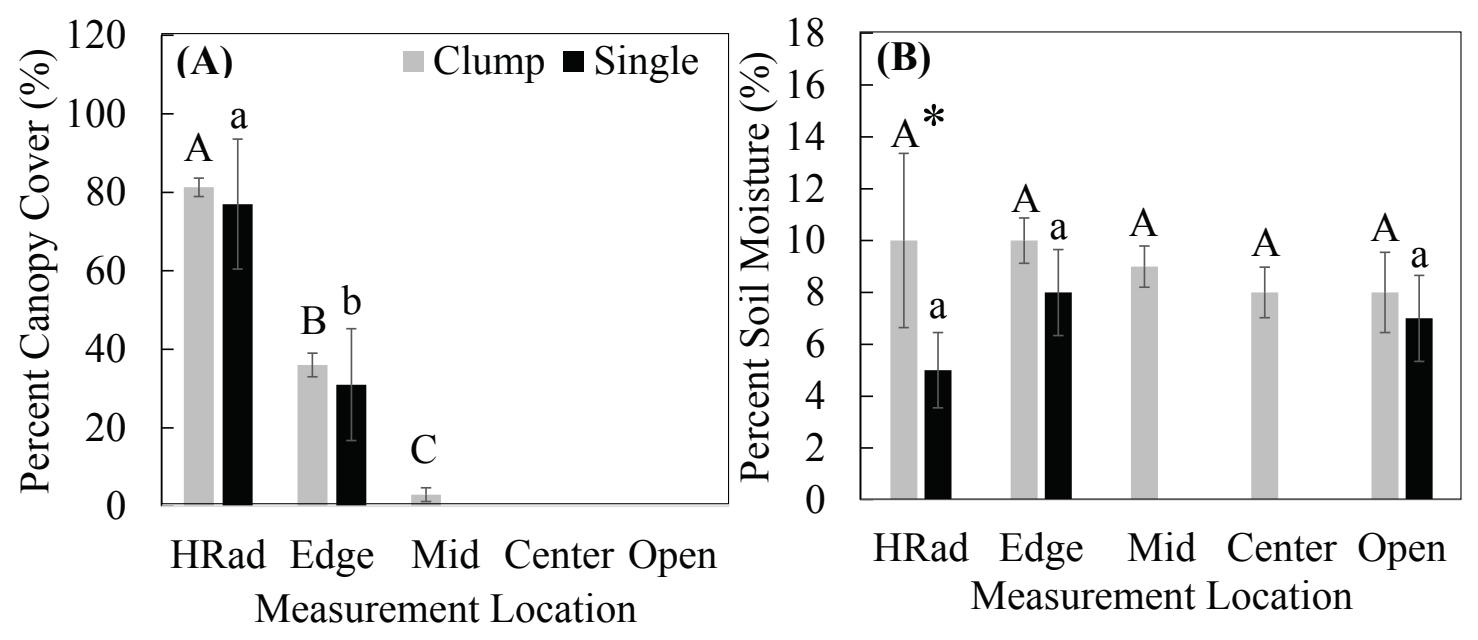

Figure 26: (A) Mean percent cover of each measurement location of single and clumped trees. (B) Percent moisture of each measurement location of single and clumped trees.

Bars with the same letters are not significantly different; capital letters are within clumped only and lower case letters represent within the single trees only.

Significance: $\alpha=0.05$. Asterisk indicate significant difference within measurement location; Significance: $\alpha=0.1$ 

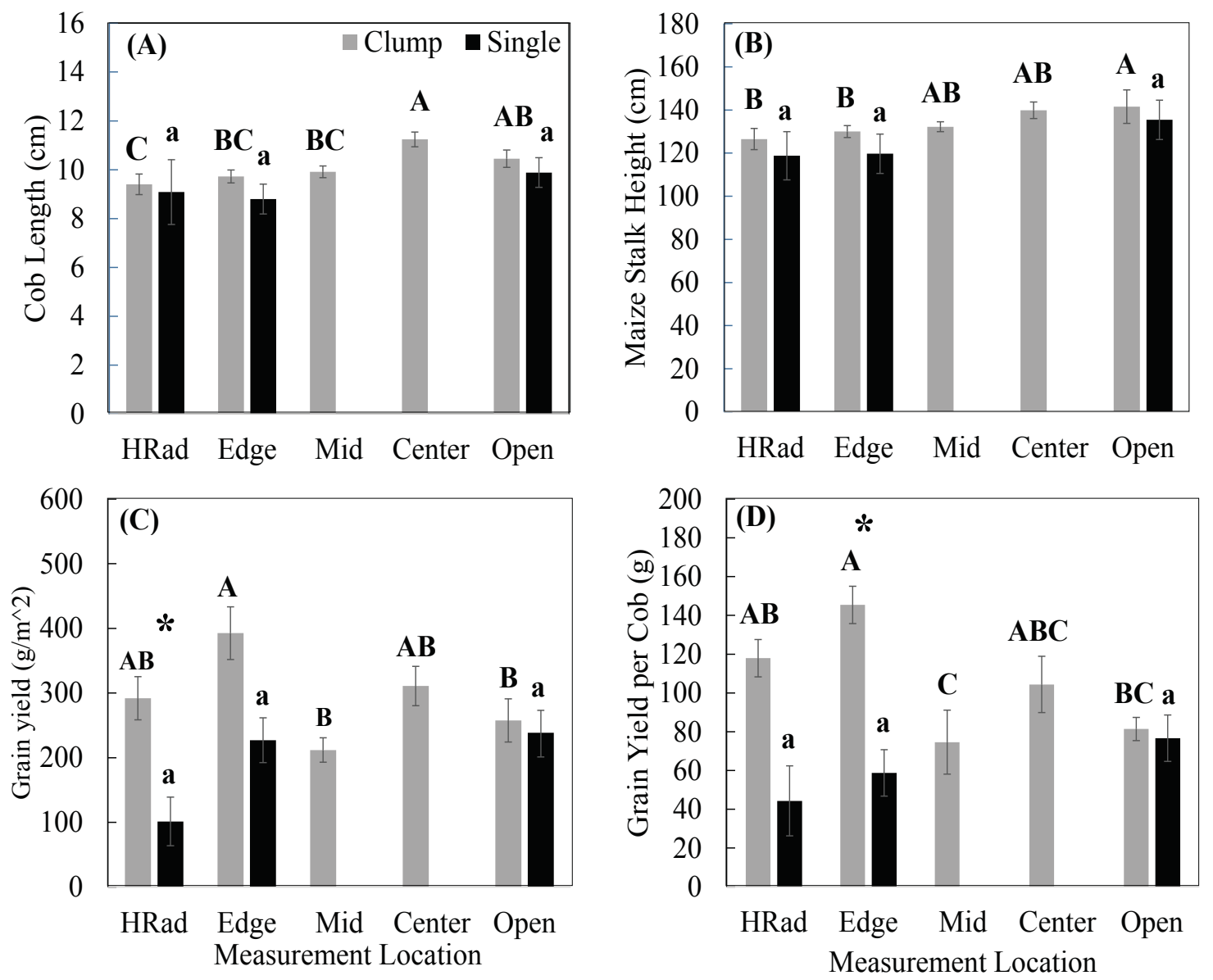

Figure 27: Vegetative and yield effects on maize crops associated with single and clumped trees. (A) Mean cob length of each measurement location of single and clumped trees. (B) Mean maize stalk height of each measurement location of single and clumped trees. (C)Mean gain yield per meter squared plot if each measurement location of single and clumped trees measured in grams. (D) Mean gain yield per cob of each measurement location of single and clumped trees measured in grams

Bars with the same letters are not significantly different; capital letters are within clumped only and lower case letters represent within the single trees only.

Significance: $\alpha=0.05$. Asterisk indicate significant difference within measurement location; Significance: $\alpha=0.1$ 

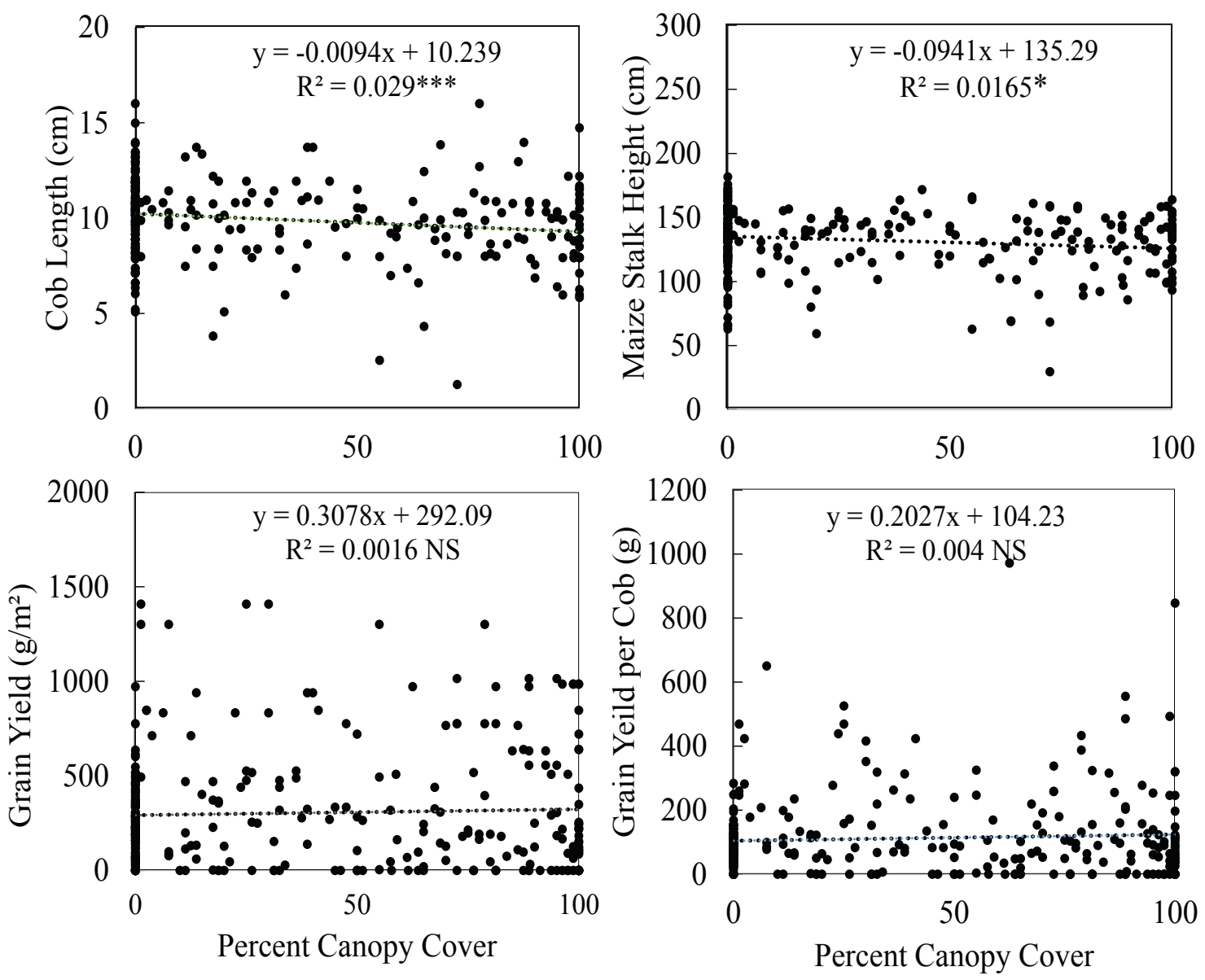

Figure 28: Correlations between percent canopy cover. (A) Mean cob length in centimeters (B) Mean maize stalk height in centimeters (C) Mean grain yield per square meter plot in grams (D) grain yield per cob in grams

Significance: $* * *=\mathrm{P}<0.001 ; * *=\mathrm{P}<0.01 ; *=\mathrm{P}<0.05$

No significance: NS 

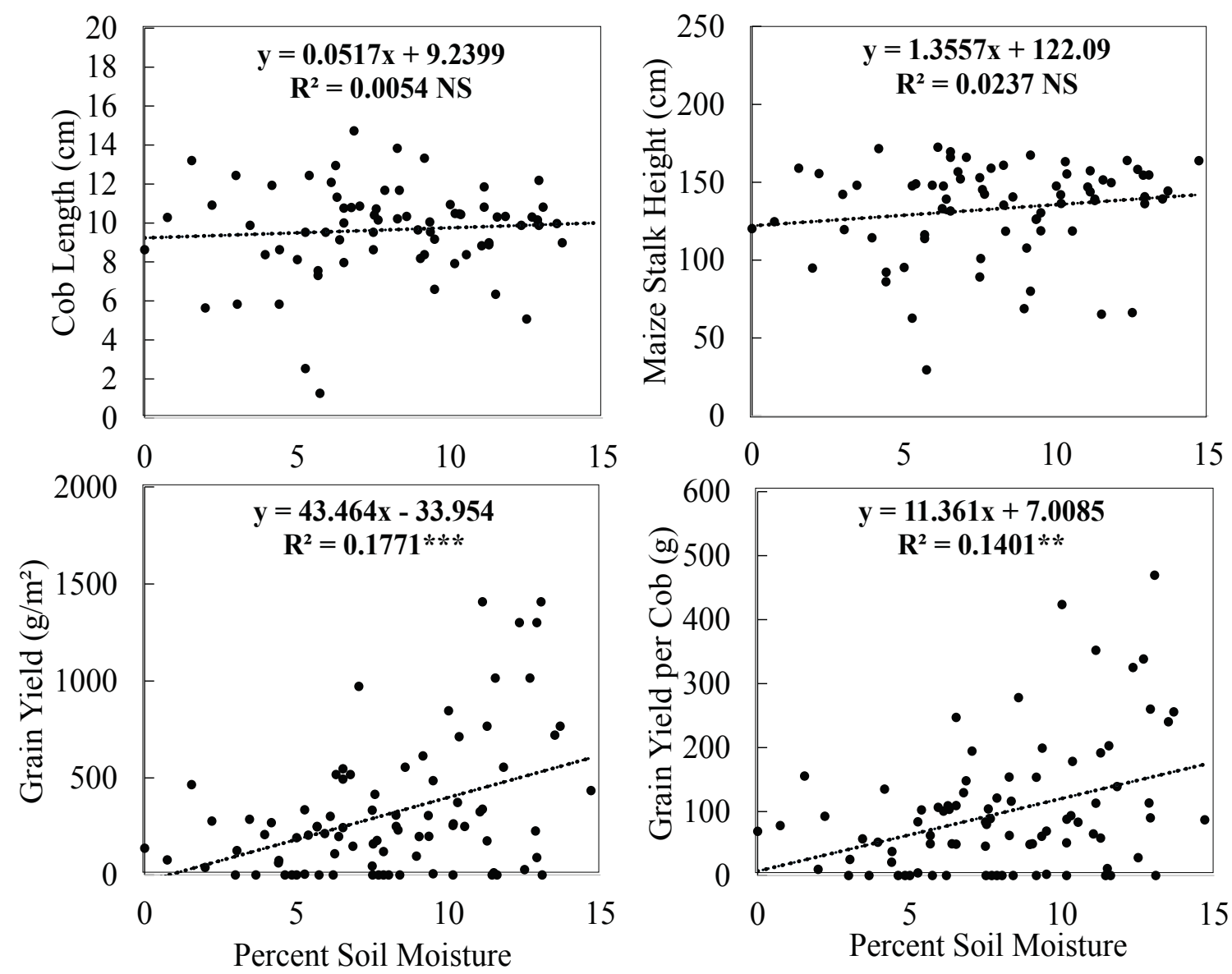

Figure 29: Correlation between percent moisture (A) mean cob length in centimeters (B) mean maize stalk height in centimeters $(\mathbf{C})$ mean grain yield per meter squared plot measured in grams, and (D) grain yield per cob measured in grams

Significance: $* * *=\mathrm{P}<0.001: * *=\mathrm{P}<0.01: *=\mathrm{P}<0.05$

No significance: NS 


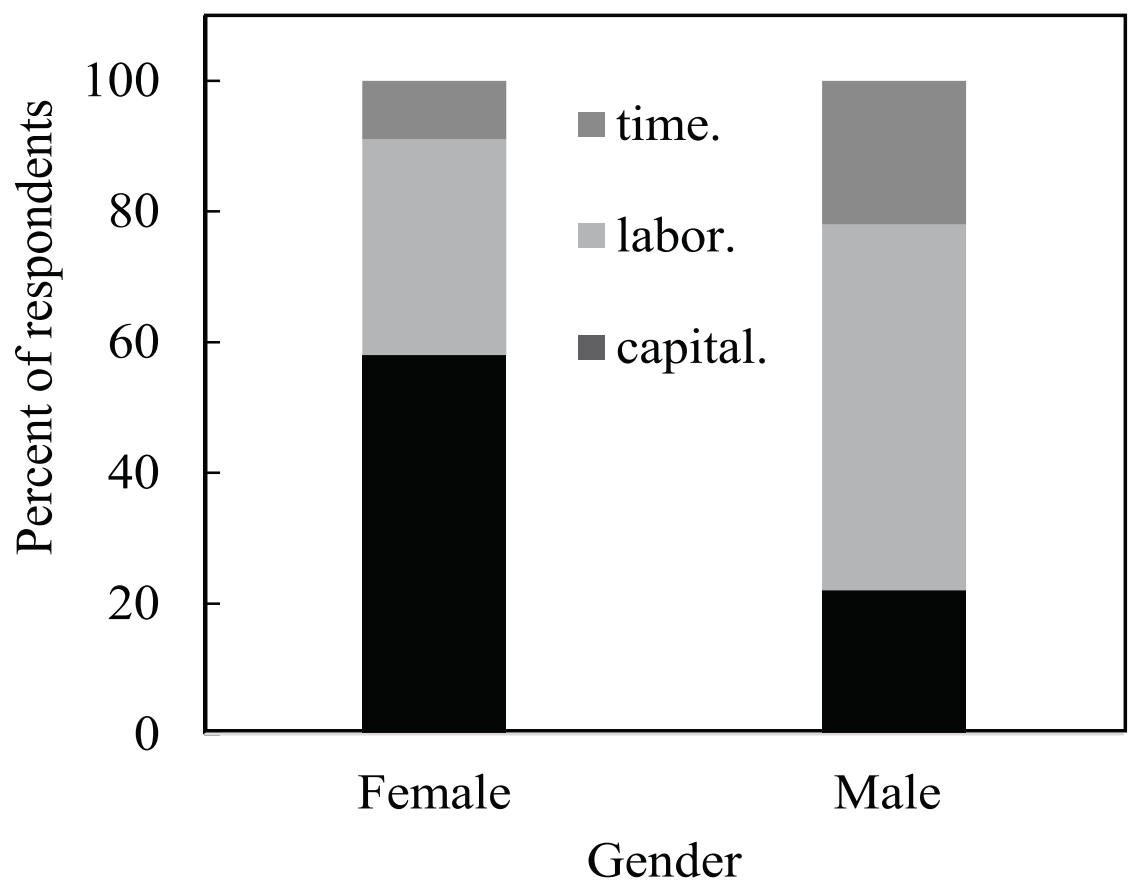

Figure 30: Women's farming constraints as perceived by women and men 


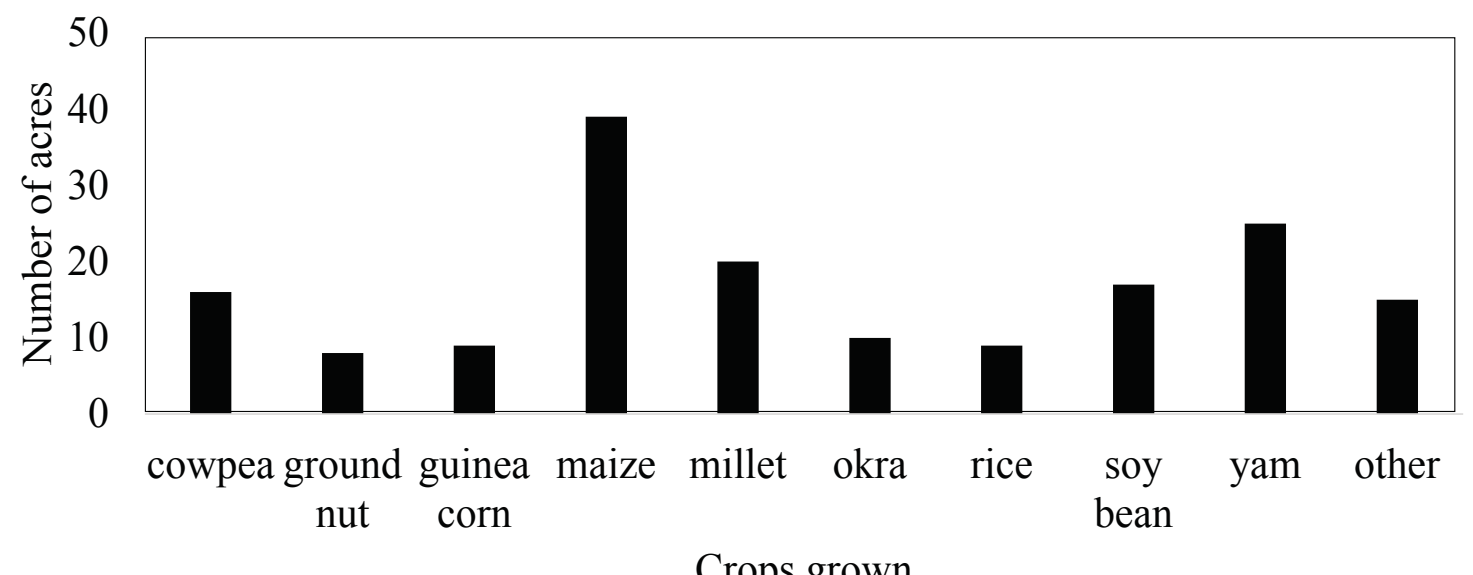

Figure 31: Crops grown by number of acres of farmers. Crops within other include: cassava, sorghum, watermelon, tomato, and bambara beans 


\section{APPENDIX A}

Table 5: Number of subplots per location of single trees and clumped trees

\begin{tabular}{|c|c|c|c|c|c|c|}
\hline \multicolumn{7}{|c|}{ Number of sub-plots per location of Clump Tree } \\
\hline Farm ID & HRad & Edge & Mid & Center & Open & Total \\
\hline MAH & 26 & 26 & 13 & 6 & 9 & \\
\hline ECO & 10 & 10 & 5 & 0 & 6 & \\
\hline SED & 14 & 14 & 7 & 3 & 5 & \\
\hline 1_SAL & 20 & 20 & 10 & 6 & 6 & \\
\hline 2_SAL & 18 & 18 & 9 & 4 & 6 & \\
\hline 1_MOS & 3 & 3 & 2 & 0 & 3 & \\
\hline 2_MOS & 4 & 6 & 3 & 1 & 3 & \\
\hline Total & $\mathbf{9 8}$ & $\mathbf{9 8}$ & $\mathbf{4 9}$ & $\mathbf{2 0}$ & $\mathbf{3 8}$ & $\mathbf{2 5 5}$ \\
\hline \multicolumn{7}{|c|}{ Number of sub-plots per location of Single Tree } \\
\hline MAH & 2 & 2 & 0 & 0 & 2 & \\
\hline ECO & 2 & 2 & 0 & 0 & 2 & \\
\hline SAL & 2 & 2 & 0 & 0 & 2 & \\
\hline SAL & 2 & 2 & 0 & 0 & 2 & \\
\hline MOS & 1 & 1 & 0 & 0 & 1 & \\
\hline Total & 9 & $\mathbf{9}$ & $\mathbf{0}$ & $\mathbf{0}$ & $\mathbf{9}$ & $\mathbf{2 7}$ \\
\hline
\end{tabular}




\section{APPENDIX B}

\section{Request for a Waiver of Written Consent}

I will be working with a population with a low literacy rate, and they are not accustomed to signing forms. A written consent may be intimidating and/or impractical. I am requesting a waiver of written consent and plan to orally inform participants about my study and their rights to participate. I do not speak the local language. I will use a translator that I trust to deliver the following oral model. The translator will be a member of the village who the participant knows and is familiar with. I will inform the translator that the conversations what I have with participants is confidential and that they are not to repeat any part of the conversation to other people. I will document their consent by means of field notes and a tape recorder. The purpose for subjects to identify themselves by name is not important for this study. However, I will keep records of who participated for my personal records. I will safeguard confidentiality by maintaining data on a password protected laptop as well as in my field notes that will be locked in my house. Exposure of subject participation either seen or heard by others would not increase any risks to me or the subjects from authorities such as local tribe leaders, governmental agencies, police, employers, parents, etc. If any risks occur any information given to me by the subject will be destroyed and removed from the study. I believe that there is no potential harm such as physical, professional, psychological or personal that would happen upon subjects participating in this study. I will use my judgment and the advice of my translator if the subject participation would cause them any harm, and the interview will end immediately and all material will be destroyed.

\section{Oral model}

I am a graduate student and Peace Corps volunteer from Michigan Technological in the United States. I am conducting a study at my school to for completing my academic degree. I would like to talk to you about your farming practices and how you manage shea on your farm. I would like to tape record our conversation, so that I can accurately record your response and transcribe it into English. You may ask me to turn off the machine at any time if you become uncomfortable and no longer wish to be recorded.

You may ask me questions at any time and talk about things you think I should know about, even if I don't ask. You should feel free to interrupt me if you want to ask questions about this study. You are not required to talk to me or answer my questions. Even if you decide now to talk to me about your farming practices, you may later ask me to stop asking you about it. When you ask me to stop, I will stop asking you. Nothing bad will happen to you or me if you decide to not answer my questions about your farming practices.

I will not reveal anything that you say to me beyond anyone helping me whom I trust to maintain your confidentiality. I will do everything I can to protect your privacy, but there is always a slight chance that someone could find out about our conversation. 
I am asking if you would agree to participate in this study, and to talk to me about your farming practices. Do you agree to participate, and will you allow me to tape record our conversation 


\section{APPENDIX C}

\section{Women's Responses}

\section{1.) Do men or women tend to keep more shea trees on their farms? Why?}

30-40

- Women have more shea trees, women want the shea nut fruits

- Men, who own the shea trees, but since women use them for their own things, it is the women who have time for it.

- Women have more shea on the farm because they get more profit

- She intends to keep more trees on the farm that her husband. He cuts the dry trees, he consults with wife before cutting healthy tree

- Women tend to keep more. Her husband doesn't like cutting the trees down

- Women use Shea fruit to sell for school fees and for farming in the next season, food

- Women have more shea trees, women want the shea nut fruits

40-50

- Women, they gain more profit on is they can use it to pay their child's school fees

- Women, because they get fruit from the tree to eat and shea butter to eat from the tree.

- Women, they get profit from the shea fruit, you can sell it to get profit of you can use it for shea butter

- Women, collect shea and gain profit from it

- Yes, because on it and protect it from fire. They benefit from it

- $\quad$ No purpose, just shea fruit

- She would like to keep the trees on her farm more than her husband

- She owns the trees

\section{$50-60$}

- Women tend to keep more shea trees on their farm- they get more profit from it.

- Women tend to keep more shea trees on their farm than men

\section{2.) How do you prefer the trees to look on your farm? Scattered or clumped together.}

\section{0-40}

- She likes scattered, because if the trees are clumped the food cannot germinate

- Scattered, that is how it can produce more fruits

- She likes them more if they are scattered 
- Scatter their trees, when the trees are in clumps thy will cut them down this is to help the plow come through

- She likes scattered, because if the trees are clumped the food cannot germinate

\section{0-50}

- She like them scattered because that is how they produce more fruit than if they were clumped together.

- She wants her trees to be scattered, if they are too close together it will destroy the crops. The shade makes the plants grow smaller, bad yield

- She wants them to be scattered. If they are clumped there is too much shade and the crops don't grow well

- She likes them to be scattered

- On her farm her trees are scattered

\section{0-60}

- She prefers that the shea trees are clumped together. If the trees are clumped she can collect more $\mathrm{b} / \mathrm{c}$ it is easier to get to the trees. If they are scattered she won't get as much shea.

\section{3.) How do you remove trees on your farm to get the spacing that you want? 18-30}

- They cut shea trees down for space so the tractor can plow. They cut trees based on space not desirable characteristics

- They don't do anything to the trees, they have them on the farm

\section{0-40}

- She just cuts them for the spacing they like

- Sometimes they remove unwanted trees from the farm, if they need spacing, but they leave the shea trees.

- They will cut them down when they need more space for farming

- The tractor removes them / When trees are plowed more shea grows then when it is not

- Cuts the trees if they are dried up. Don't cut the tree clumps - prune to allow tractor to come through

- No, just waits for death. If a tree is growing in a favorable place they will allow it to grow - prevent space competition - cutting shea trees down in illegal in bulenga

40-50

- When she needs space, she will burn them or cut them. Normally the trees with no benefit, but they leave the shea trees.

- If there are 4 trees in a space they will want to remove 2 , if there are 3 in a space they would like to remove 1 
- She cuts them to get the spacing that they like, assuming that there are 5 trees, she will cut 2 leaving three

- They will burn them to get spaces for farming, they don't cut shea trees only the trees that don't provide anything to them

- She removes all non-shea trees. If they are too close she will remove them

- No cutting, but close contact to other trees they will decide to cut them down

- If they start to die

- They leave the trees to grow even when they are clumped

\section{0-60}

- She keeps them for the nuts. She doesn't cut shea off her farm

- Don't normally cut shea trees. She will cut other trees near the shea, but not the shea. She just lets them die on their own. She allows trees to grow and some die.

\section{4.) Do you notice more or less fruit production of shea trees when trees are clumped together or when they are spread out?}

\section{8-30}

- More seeds in scattered distribution

\section{0-40}

- More fruit comes when trees are one one

- They produce more fruit when they are scattered together, but less when they are clumped

- When trees are scattered they yield more fruit when they are clumped together

- Single trees produce more shea

- Shea that is clumped in one area have more fruit production than the single trees

- Clumps of trees grow fruit as well as scattered trees, no difference

\section{0-50}

- She notices there is more fruit when the trees are close together.

- Depends on a yearly basis, there are good and bad yield years. Being scattered or clumped doesn't make a difference

- More fruit when they are scattered

- If trees are scattered they produce more fruit, but if they are close together they don't produce more fruit

- If they are clumped together there is less fruit production

- When they are separate

\section{0-60}

- Yield is the same if they are clumped and scattered. Seasonally, some shea have more and some shea have less than last year. Last year everyone was able to get bags 
- More fruit produces when trees are clumped together

\section{5.) Do you notice a change in the amount of shea trees on the landscape from when you were a child?}

30-40

- Yes, now the small trees there are more

- Notice that there is an increase of shea trees on her farm land.

- Since she has started farming she notice an increase of shea trees on the farm

- Have not noticed a decline in shea trees, now the trees bear more fruit than before

- Have not noticed a decline in shea trees, trees are bearing for fruits now

\section{0-50}

- She has noticed reduction of shea trees on the farm land

- There were no trees when she was a child. Charcoal and roofing are causing them to decrease. The trees are also dying on their own

- She notices that there is an increase in the shea trees on the farm

- She notices that there is an increase of shea trees on the farm

- Yes, there is an increase of shea on the farm. Daughter said - they do this now because they realize the benefit from it.

- Decline of shea trees on the farm - fire is stopping them from growing

- Increase in shea trees on the farm

- Notice a decline in trees, they dry up and they cut them

\section{0-60}

- She notices a decline of shea from when she was young.

- Increase in tree on her farm from when she started farming, decrease in fruit production

- Crop yield is low under trees

\section{6.) Do shea trees cause trouble for you when you are trying to farm? Do they create obstacles?}

- No trouble

$$
\text { 30-40 }
$$

- No, since they need them, the tractor can find their way out.

- Yes, they create obstacles but the tractor will maneuver around and whatever the tractor misses they will go in and weed the place.

- Yes, b/c of the shade sunlight prevents the crops from growing b/c of the fruits they don't cut them

- Shea trees don't have any nuisance on her crops

- Yes, they cut the trees b/c some crops don't like the shade

- No obstacles 
- No, farming obstacles. If there are too many trees on the farm that she wants on the farm she will need to remove some

- Don't create any obstacles since she is able to scatter them

- The trees don't create any obstacles

- No

- Shade of trees causes crops not to grow well

- Shea fruit - use for school fees, don't do anything for the crops, Shade effects the crops

\section{0-60}

- She doesn't cut trees. If the trees are clumped the tractor can get around, or they don't plow that area and she will weed it by hand.

- She doesn't cut trees down for tractor, but will prune to help the tractors to go through

\section{7.) Do shea trees on your farm ever go through periods of low fruit production?} Do you ever wonder why?

\section{8-30}

- More trees produce more seed than others

- More fruit comes when trees are one one

\section{0-40}

- Sometimes we have less rainfall that can sometimes effect the production

- Yes, sometimes there is low production, but they think it is a normal year. In farming, one year you can get, another year you farm you can't get. It is the same for shea, it is a natural thing.

- She doesn't know if trees go through low production. If the rain comes early more fruit is produced - she thinks

- They notice a difference in fruit production when they have applied fert. More fruit when fert. is applied

- If they stop farming on the land there will be a decline in shea fruit 40-50

- She notices that there is an increase in the shea fruit now than before. She doesn't wonder why because it is nature

- Different years, different yield. She notices that cause is due to bush burning

- When they fallow land the shea trees in general will have less fruit than the trees that they are farming on

- Sometimes there is always a low production but sometimes they have high production. She doesn't know why, she thinks that maybe they are old

- Yes, seasonal difference

- Doesn't know about low/high production of fruit, but maybe when rain comes early the shea will have more fruit 
- They don't think too much about low and high production. They rather say that id is because of god.

- There is a change in fruit production from year to year, but she doesn't know why

\section{8.) How does bush burning affect your shea trees? Do you do anything to protect them?}

- fire stops shea nut production

18-30

- The fire will burn the leaves

- The fire will burn the leaves

30-40

- She doesn't protect them. Is she leaves the farm for a year the bush can enter and destroy the shea trees, but if they are farming there the fire cannot come and destroy the trees

- If you farm on the land, it is difficult for the fire to reach the trees

- Weeding around the trees during bush burning waits for natural death

- Low production $-b / c$ of bush burning - when the grass is high on the trees they notice a decline - intense fire?

- They create fire belts around the trees

40-50

- Sometimes the fire can burn the trees on the farm, her husband has run away so she will leave her farm for some time, so the fire will come and enter the farm because the bush was able to grow.

- If the grass is too high the fire will burn the trees too bad. It burns the flowers. She clears the grass under the trees

- When they are farming on the land then the fire can't get into the farm. Even if the farm is bushy and the fire enters it will not be big enough to affect the trees

- If she is farming fire cannot come and burn the shea

- Yes, it causes low fruit production. Yes, weeding around and farming around the trees

- Weed around the trees or spray herbicide

- Weed around the tree/apply herbicide

50-60

- She makes a fire belt around the trees so that they fire doesn't bother them.

- She weeds/ clears under the trees/ bush burn

\section{9.) Have you ever transplanted or planted shea?}

- No, never planted

18-30 
- Natural growing, grows by itself

- No

\section{0-40}

- No

- No

- Has never planted, she would never plant trees

- Shea plantation, but since growing up she didn't see anyone growing shea plantations, so she doesn't see an importance in that

- Has the mindset to have a plantation. When growing up their parents didn't do it, why should they?

- She doesn't grow shea - they have had the thought to farm shea

40-50

- No

- No, they grow themselves. Never planted any type of tree

- No

- She has never thought of it

- No

- Don't plant, the trees that are there are for easy maneuver

- She has the idea of having a plantation of shea trees. The shea trees are there plenty so they don't need to plant them financial is always the problem

\section{0-60}

- No

- Never planted shea trees

- She would have a shea plantation if there was someone to help her

\section{0.) Are there differences in the way men and women manage their farming practices? What are some of the differences?}

30-40

- Some of the women don't have the capital to start. If the man doesn't help the women can't do the work. It is the men who have to take more of the part.

- Woman manage their farm, but a man is having a farm you go and help them

40-50

- She manages the farm herself so she can do everything the man is doing.

- Yes, men go to farm more regularly so they are able to get better yield. Women need to hire more labor b/c they aren't able to do it themselves

- Most of the time if the men have yam farms the women can't help, but if it crops like maize, then women can help. They also have their own farms and they can manage it fine

- Mostly, the men manage the farm, but if you are a women you manage your own farm alone, but you have to help you husband since he is the man of the house. 
- Men, can do their own, but it is more difficult for women because they don't have the man power. They have to pay for help men don't.

50-60

- Yes, men manage their farms more than women, in Ghana people believe that women don't farm, or they are comparing themselves to their husbands. Even if the women is having more $\$$ than the man.

\begin{tabular}{|c|c|c|c|c|c|c|c|}
\hline age & Acres & Crops & Farms & Fallow & $\begin{array}{l}\text { Fallow } \\
\text { changed? }\end{array}$ & Rotates & extra \\
\hline 28 & 5 & $\begin{array}{l}\text { soy, yam, } \\
\text { cowpea, } \\
\text { black eyed } \\
\text { pea, } \\
\text { cassava } \\
\text { sorghum }\end{array}$ & & & & & $\begin{array}{l}\text { Husband decides } \\
\text { what is grown }\end{array}$ \\
\hline 30 & 6.5 & $\begin{array}{l}\text { Maize, } \\
\text { millet soy } \\
\text {-millet } \\
\text { major, soy } \\
\text { minor }\end{array}$ & $\begin{array}{l}3 \\
\text { farms, } \\
1.5,1,4\end{array}$ & & & & $\begin{array}{l}\text { She decides what } \\
\text { is grown on the } \\
\text { farms, } \\
\text { She also works } \\
\text { on the farms, } \\
\text { friends and } \\
\text { family, Husband } \\
\text { is in charge of } \\
\text { crops grown, she } \\
\text { decides what is } \\
\text { grown, but the } \\
\text { husband is in } \\
\text { charge of selling } \\
\text { and } \$ \text { - he makes } \\
\text { planting decision }\end{array}$ \\
\hline 30 & 1 & $\begin{array}{l}\text { Okra } \\
\text { millet } \\
\text { maize } \\
\text { beans } \\
\text { Bambara }\end{array}$ & 2 & 2 years & & & \\
\hline 30 & 4 & $\begin{array}{l}\text { Maize, gn, } \\
\text { soy }\end{array}$ & 2 & & & & \\
\hline 35 & 4 & $\begin{array}{l}\text { Soy gn } \\
\text { okra }\end{array}$ & 1 & \multicolumn{3}{|c|}{ Doesn't fallow, no rotation } & \\
\hline 35 & 4 & $\begin{array}{l}\text { Soy, rice, } \\
\text { gn, yams } \\
\text { Bambara }\end{array}$ & 4 & $\begin{array}{l}\text { Fallows } \\
\text { farm } \\
\text { for one }\end{array}$ & $\begin{array}{l}\text { Changed } \\
\text { from } 1 \\
\text { year to } 4 \\
\text { years }\end{array}$ & & $\begin{array}{l}\text { Farm loses } \\
\text { strength so she } \\
\text { fallows it. }\end{array}$ \\
\hline
\end{tabular}




\begin{tabular}{|c|c|c|c|c|c|c|c|}
\hline & & & & $\begin{array}{l}\text { year at } \\
\text { a time }\end{array}$ & $\begin{array}{l}\text { every } \\
\text { once in a } \\
\text { while, } \\
\text { sometimes } \\
\text { she needs } \\
\text { to leave } \\
\text { the field } \\
\text { fallow for } \\
\text { longer }\end{array}$ & & \\
\hline 35 & 3 & $\begin{array}{l}\text { maize } \\
\text { rice, } \\
\text { miller }\end{array}$ & 1 & no & & no & $\begin{array}{l}\text { No } \$ \text { for fert } \\
\text { they grow both } \\
\text { maize and rice at } \\
\text { the same time so } \\
\text { that the fert can } \\
\text { effect both crops, } \\
\text { they apply } \\
\text { fertilizer in the } \\
\text { middle of the } \\
\text { crops - plowing } \\
\text { and fertilizer is a } \\
\text { problem. farms } \\
\text { with her husband }\end{array}$ \\
\hline 40 & 4 & $\begin{array}{l}\text { lac okra, } \\
\text { maize, } \\
\text { millet }\end{array}$ & 1 & no & & $\begin{array}{l}\text { Rotate } \\
\text { maize } \\
\text { and } \\
\text { millet }\end{array}$ & $\begin{array}{l}\text { Her and her } \\
\text { husband work } \\
\text { together on the } \\
\text { farm - can plow } \\
\text { land but fert is } \\
\text { difficult. Can } \\
\text { only afford fert } \\
\text { for } 1 / 2 \text { their field }\end{array}$ \\
\hline 40 & 3 & $\begin{array}{l}\text { maize, } \\
\text { yam, } \\
\text { millet, gc }\end{array}$ & 3 & $\begin{array}{l}\text { Fallows } \\
\text { for } 1 \\
\text { year }\end{array}$ & & $\begin{array}{l}\text { Rotates } \\
\text { maize } \\
\text { /okra }\end{array}$ & $\begin{array}{l}\text { Was going to } \\
\text { grow maize - } \\
\text { Didn't grow } \\
\text { maize this year } \\
\text { due to fert } \\
\text { increase - crop } \\
\text { loss... Sunshine } \\
\text { and rain too } \\
\text { much }\end{array}$ \\
\hline 40 & 5 & $\begin{array}{l}\text { Maize, } \\
\text { beans, } \\
\text { rice, } \\
\text { cowpea, } \\
\text { Bambara }\end{array}$ & 1 & 3 years & no & no & $\begin{array}{l}\text { When you go } \\
\text { back to that } \\
\text { field, it always } \\
\text { produces more } \\
\text { crops }\end{array}$ \\
\hline
\end{tabular}




\begin{tabular}{|c|c|c|c|c|c|c|c|}
\hline 40 & 4 & $\begin{array}{l}\text { maize, gn, } \\
\text { okra }\end{array}$ & 1 & 1 & no & & $\begin{array}{l}\text { Biggest loss in } \\
\text { yields from } \\
\text { weather change }\end{array}$ \\
\hline 42 & 3 & $\begin{array}{l}\text { 1soya, } \\
\text { 1maize, } \\
\text { 1millet }\end{array}$ & 1 & 3 & 3 & & $\begin{array}{l}\text { b/c the land loses } \\
\text { its fertility if you } \\
\text { continue to farm } \\
\text { in that place you } \\
\text { won't get a good } \\
\text { yield }\end{array}$ \\
\hline 45 & 10 & $\begin{array}{l}\text { Maize, } \\
\text { millet, gn, } \\
\text { beans, gc, } \\
\text { yam }\end{array}$ & 1 & & & yes & $\begin{array}{l}\text { shares farm with } \\
\text { her husband }\end{array}$ \\
\hline 45 & 7 & $\begin{array}{l}\text { Okra, rice, } \\
\text { soy, } \\
\text { maize, } \\
\text { beans, gn, } \\
\text { yams }\end{array}$ & $\begin{array}{l}2 \\
\text { farms } \\
-4 \& 3 \\
\text { acres }\end{array}$ & $\begin{array}{l}\text { She } \\
\text { will } \\
\text { fallow } \\
\text { for } 3 \\
\text { years } \\
\text { before } \\
\text { going } \\
\text { back }\end{array}$ & & $\begin{array}{l}\text { She } \\
\text { rotates } \\
\text { always } \\
\text { with } \\
\text { legume, } \\
\text { she also } \\
\text { rotates } \\
\text { okra } \\
\text { with } \\
\text { rice }\end{array}$ & $\begin{array}{l}\text { Didn't have } \$ \text { to } \\
\text { farm maize - } \\
\text { increase in fert - } \\
\text { she likes maize } \\
\text { b/c she can get } \\
\text { many bags, but } \\
\text { with soya she } \\
\text { doesn't have to } \\
\text { apply - Cashews } \\
\text { are on the farms } \\
\text { - gave to her } \\
\text { husband no one } \\
\text { can claim the } \\
\text { land now that the } \\
\text { trees are there }\end{array}$ \\
\hline 50 & 10 & $\begin{array}{l}\text { Maize, } \\
\text { okra, soya, } \\
\text { gn, beans }\end{array}$ & 1 & & & yes & \\
\hline 50 & 6 & $\begin{array}{l}\text { maize, } \\
\text { millet, } \\
\text { okra }\end{array}$ & 1 & no & & $\begin{array}{l}\text { Rotate } \\
\text { maize } \\
\text { and } \\
\text { millet. }\end{array}$ & $\begin{array}{l}\text { difficulty buying } \\
\text { fertilizer - They } \\
\text { struggle with } \\
\text { applying fert to } \\
\text { all of their field } \\
\text { Some land is too } \\
\text { fertile it can } \\
\text { contain the } 2 \\
\text { crops on that } \\
\text { land. Millet } \\
\text { grows during } \\
\text { harmattan, she } \\
\text { grows maize }\end{array}$ \\
\hline
\end{tabular}




\begin{tabular}{|c|c|c|c|c|c|c|}
\hline & & & & & & $\begin{array}{l}\text { during rainy } \\
\text { season. }\end{array}$ \\
\hline 60 & 1 & maize & 1 & no & & $\begin{array}{l}\text { Farms alone, can } \\
\text { afford plow, but } \\
\text { fert is difficult }\end{array}$ \\
\hline 64 & 1 & maize & 1 & & & $\begin{array}{l}\text { She is in charge } \\
\text { of the crops, } \\
\text { sells some for } \\
\text { food - she works } \\
\text { on other farms - } \\
\text { family members }\end{array}$ \\
\hline 66 & 3 & $\begin{array}{l}\text { Soy1, } \\
\text { maize1, } \\
\text { tomato1/2, } \\
\text { beans1/2 }\end{array}$ & $\begin{array}{l}2 \\
\text { farms } \\
-2 / 1 \mathrm{ac}\end{array}$ & $\begin{array}{l}2 \text { years } \\
\text { at a } \\
\text { time }\end{array}$ & $\begin{array}{l}\text { She } \\
\text { switched } \\
\text { between } 2 \\
\text { and } 3 \text { year } \\
\text { fallows }\end{array}$ & $\begin{array}{l}\text { The farm will } \\
\text { lose strength so } \\
\text { they leave the } \\
\text { farm to gain } \\
\text { strength - it is } \\
\text { not difficult to } \\
\text { get farmland, } \\
\text { there is plenty } \\
\text { land and the } \\
\text { population of } \\
\text { bulenga is small. }\end{array}$ \\
\hline
\end{tabular}

\section{Men's Responses}

\section{1.) Do men or women tend to keep more shea trees on their farms? Why?}

\section{8-30}

- Men, they want shea trees to be on their farms b/c they get income

- Men, because men are there and they are looking after the trees, if they want to cut it they can.

\section{$30-40$}

- Men, because men are the owner of the farm

- The shea trees belong to the women. The farm belongs to the family

- Men, because the wife can sell them. If there is not food on the farm, it serves as a whole purpose to the family, and he is to take care of the family, since he is on the farm he can eat them if he is hungry

- Men, because the men are taking care of the women

- Women, had it been left with the men, they would have done away with them. It is because of the women that they are around

- Men keep the trees, but the women want them to keep it

- Men, because men are the owner of the farm 
- Women keep more shea on their farm because it helps them a lot sometime it is balances but the woman are the final on it.

\section{0-50}

- Yes, women are having more shea because they get more benefit

- Men tend to keep more shea on the farm they get the fruit from the trees and butter his wife is collecting and processing

- Women keep more shea, women get more benefit from the shea

- Men b/c he leaves them for the women to harvest for oil to cook their beans on the farm. When he is farming he can eat the shea in the farm if he is hungry

- The men will have more shea because they are more hard working. They can look around the farm to protect from fire. They can also remove parasites. Also, women could have more b.c men don't pick

- Women like shea nut therefore women like more shea on their farm

- Men, they leave the shea tree to grow, but they don't pick them. It is the women who pick.

- Women, because men don't pic the shea

- Men, because men are the farmers and they are looking after the trees. If he wants to cut the trees he will cut them if not he won't cut them.

\section{0-60}

- Women's farms have more, they feel that it is more economical

- Women tend to leave more shea trees on the farm because they tend to use it more than the men, the can use it for shea butter

- Men, because the land belongs to the men

- Male, usually have more. The men farm is bigger than the women

- No owner, shea trees are not owned. By weeding you are showing ownership, but if you decide not to farm there any more (or weed) the tree can belong to another person

\section{2.) How do you prefer the trees to look on your farm? Scattered or clumped together?}

\section{8-30}

- He wants them to be scattered to free the crops for air passage

- Scattered, if they are clumped it is bad for the crops

30-40

- Scattered, because if they are too close they might not get enough oxygen 
- If they are too close they will remove trees if the shea trees are also too close they will remove some

- Scattered

- He likes them scattered - if the trees are close together, the crops will not do well

- Pruning, or cutting the ones that don't want, you cut (non-shea). Cut the ones who don't bear fruits

- Scattered

- Scattered, because if they are too close they might not get enough oxygen

- Scattered

40-50

- He wants the trees to look scattered

- Scattered, when they are clumped there is too much shade.

- Scattered, but if they are clumped and you grow any plant in that area the yield is always low

- Scattered, because there will be too much shade in clumped areas

- They like the shea tree to be scatted b/c if they are close the crops won't grow. Women like the shea nut but if it were left to him he would remove all treesdon't chose based on fertility of the land where they grow is where they grow.

- Scattered

- They want them to be scattered - if they are too clumped the shade of the trees disturbs the crops

- Scattered

\section{0-60}

- Scattered

- Since shea are not planted by men some tend to be scattered and some tend to be clumped, he doesn't worry about how they grow, they just grow

- Scattered, because nature plants the trees - he didn't plant himself

- Some are not scattered, when it is like that you don't get a good yield

- If you allow trees to grow if will become over crowded. You have to cut some and allow some to grow - Cutting and burning trees allows for fert. Tractors cannot get through with too many trees in the way. Even if they used ox and plow they wouldn't allow many trees to grow

- No difference, but allowing space btw trees is good for the crops, it allows them to get more sun

- When trees are clumped they try to space them out. If the trees are clumped it is natural

\section{3.) How do you remove trees on your farm to get the spacing that you want?}

\section{8-30}

- He only removes unwanted trees, but he doesn't remove shea 
- He removes the other trees, but not the shea trees

\section{0-40}

- Spacing, there is a certain measurement that the farmer uses, the farmer like trees that bear the most fruit

- As you watch the farm, The trees that are not having fruit of that have yellowish leaves will keep them off

- If you remove you remove unwanted trees leaving the shea and dowa dowa

- Some trees are not bearing fruits, he burns those and leaves the one that are bearing fruit

- When trees are close together, you get less fruit

- If the trees are scattered, but if they are clumped

- Spacing, there is a certain measurement that the farmer uses, the farmer like trees that bear the most fruit

- You remove trees leaving only the shea trees

\section{0-50}

- He uses fire to remove the trees that are clumped to allow space for the others to do better

- He cuts them down. You can cut trees on your farm, but you cant just enter the bush and start cutting

- If the trees are too clumped ex 3 trees - he will remove one, 4 trees keep 3

- He removes the other trees from the shea, but even if the shea trees are too close he will remove them

- Look at the nature of the trees, you can see which are old and which are new, you can let the ones who will have more fruits to grow and clear the small trees leaving the ones that grow big and have fruits.

- He doesn't differentiate btw what tree to cut and which to leave behind. If there were five trees he would remove 3

- He removes the unwanted ones leaving the shea trees

- He wants to remove them for air to pass through, he doesn't really care if shea trees are there or not

- He doesn't remove shea, but other trees that disturbs the crops he will remove them

\section{0-60}

- The trees that fruit well with bug nuts, he likes to keep

- They don't cut the shea trees. if they need space, but the other trees they will out them and burn them

- If it is an economic tree he will leave it but all the rest he will remove

- They remove the seedlings under the tree when the trees are no longer bearing fruit he will remove them.

- you don't plant they just help the small trees to grow they cut the small trees around it/ shea fruits, they leave the trees for the fruit/ close contact btw the trees they will cut the trees - helps produce fruit 
- Trees kept on the farm are due to economic purposes - trees kept produce more butter try to keep bigger trees - Small seeds are preferred, big seeds have more left over residue when you make shea butter

- They all like to keep their shea trees because thy all benefit

\section{4.) Do you notice more or less fruit production of shea trees when trees are clumped together or when they are spread out?}

18-30

- When they are scattered they won't get a chance for air to pass through them and that will make it difficult to get more fruit

- When they are scattered you get more fruits, when they are scattered they get enough air, but if they are clumped they don't get enough space.

\section{0-40}

- Scattered have more fruit more space

- Scattered is when bear more fruits

- When they are spread out

- Trees that are scattered bear more fruit

- trees are close together, you get less fruit

- Yes, the shea trees on the farm bear more fruit than in the bush

- Due to nature, meaning some will be clumped and they can get better fruit, but sometimes they can be scattered and they don't get a lot of fruit, but mostly the scattered ones more fruit

- Scattered have more fruit more space

- Spread out

40-50

- When the shea trees are scattered, that is when more shea fruit is produced

- They all grow fruit but it can change due to fire

- More fruit production with scattered trees

- When they are scattered you get more fruits $\mathrm{b} / \mathrm{c}$ air passes through them frequently

- Scattered allows more fruit. The trees have more strength to yield fruits when they are close together they take strength from each other

- When trees are scattered the trees produce more shea nut than when they are clumped

- What they are spread out he will get a better fruit. 
- Not even shea trees, but only crop anything that is close together reduces its yield

- When they are spread out.

\section{0-60}

- More fruits when they are scattered than when they are clumped

- Scattered bear more fruit than when they are clumped

- You get more shea when they are clumped together, because there are more there.

- When they are spread out

\section{5.) Do you notice a change in the amount of shea trees on the landscape from when you were a child?}

\section{8-30}

- He doesn't know since he did not grow up in bulenga

- He notices that there is an increase in shea from as a child. When they are farming they allow the small ones to grow, with in a years' time they have grown

\section{0-40}

- Yes, shea trees, sometimes when they burn the weeds, that is when they yield more fruit from when they do not burn

- Depends on the area, some places there are many some places there are few. It depends on their natural habitation

- When he was young because his grandfather during that time never cut the shea trees, but this time the younger people are cutting the shea trees.

- As a child he saw more trees. Old times they were farming for survival, now they are farming for profit. so more trees are being burned

- Yes, less trees on the landscape from childhood

- When he was young, because these days most people like doing away with shea trees

- At first he didn't notice, but now he has grown up to see that the shea are many, but now that he is grown up he has seen that there are more than previous

- When he was young, because these days most people like doing away with shea trees 
- Yes, this time the shea trees are plenty. Years ago they didn't know the benefit (profit) that could come from them.

- He sees more shea trees not than when he was a child

- Increase in trees from childhood

- When he was young that period our grandpas don't know how to farm in acres so they would farm small acres, but now we farm in large acres so we remove the trees on the farm

- No, it hasn't changed, some are growing and some are dying. You can say that now there is even more since there are rules that tell people not to cut. In the past there was no rule.

- Trees are increasing on the landscape. When you first farm - no trees, but when you start farming for (3years) you start to see more trees.

- When he was young some people cut them to burn charcoal and some die by nature.

- When he was young the shea trees were plenty, but now since people are cutting them they have reduced

- Yes, due to settlements the trees are being reduces in numbers. His house for example, there were a lot of trees there, but they had to remove a lot so they could settle.

Doesn't notice

- Increase of shea on the farm from when he was a child. When they start farming land they see small trees starting to grow so they allow them to grow.

- Yes, increase because when he sees them germinating he won't cut it.

- Yes, the shea trees did not bear enough fruit as compared to today, because today they are building fire belts

- At the beginning fruit production was low, trees were few. Since he started farming the trees have increased

\section{6.) Do shea trees cause trouble for you when you are trying to farm? Do they create obstacles?}

\section{8-30}

- When they are clumped they find it difficult to plant that area, you cannot get a good yield. They like it when they are scattered because they find it easier to farm.

- No

30-40

- No, because be like them, they help a lot.

- When they are group a lot they cause trouble, they let your crops grow stunted 
- No

- No

- No, only the other trees

- Do to the shade of the shea trees, it causes the yield to be low

- No, b/c his farmland is not having enough shea trees.

- No, because be like them, they help a lot.

- No

40-50

- If they are scattered they are not an obstacle, but if they are clumped they become and obstacle and they need to be removed. Obstacle - they are unable to get good yield if they are clumped can't grow well.

- Yes, if there are a lot of trees too much shade. Difficult for the tractor to move through and difficult to plant in straight lines.

- Yes, b/c when the fruits fall he cannot weed. Because he will cover them so has to stop and pick them and that wastes time. He would have weeded enough of his farm, but this delays his time

- No, you can still grow crops under the shea them. Shea trees aren't too big like mahogany and dowa dowa, you can still get yield.

- Don't cause any trouble. If the shea trees are there and they are big - they cut them for the tractor to be able to move through

- No

- If the shea trees are many in that area it will bring low yield

- Yes, if you grow something like guinea corn, they will disturb the crops

- Doesn't notice

50-60

- Increase of shea on the farm from when he was a child. When they start farming land they see small trees starting to grow so they allow them to grow.

- Yes, increase because when he sees them germinating he won't cut it.

- Yes, the shea trees did not bear enough fruit as compared to today, because today they are building fire belts

- shea trees help from the wind to blowing crops down

- Good for eating and crops and sell shea butter - crops under the tree is better b.c water retention. However, insects infect the crops more. Yield under the trees and outside the tree canopy is the same

\section{7.) Do shea trees on your farm ever go through periods of low fruit production? Do you ever wonder why?}

\section{8-30}

- Every year in his field he usually gets good yield

- Sometimes it is due to nature, sometimes it is due to bush burning 
- No, not yet. Every year they burn the place early so there is no problem

- No, if only there are not too much

- Yes, most likely when bush burning enter the fields

- Yes, he sees a change, but he doesn't know why

- the shea trees on the farm bear more fruit than in the bush

- Yes, but it is due to nature

- Yes, but he doesn't know, he has given it to nature. He doesn't let fire attack his field but still he gets low yield

- No, not yet. Every year they burn the place early so there is no problem

$-$

40-50

- Sometimes, they don't bear a lot of fruits. If there are a lot of weeds and they set fire, usually that is why they don't prepare a lot of fruits.

- If bush fire, bad yield. Nature - weather poor rains can cause low yields of fruit.

- If the farm is burned the fruit production is low.

- Yes, b/c you would not be ready to clear your field but fire will enter and that will bring low fruit.

- Yes, seasons. It is natural, so you can't know why

- Depends on the seasons they don't take time to think about it b/c they see it as a normal occurrence

- Yeas, when fire burns them or alters them they don't get good yield

- Yes, if rain is low in every year then there will be low fruit yield

- Yes, b.c even mango trees or any other trees that give fruits. It is due to the seasons some seasons they will have more than others

50-60

- Yes, when there is less rain in a particular year.

- When fire burn if affects the shea trees in the bush, you notice that the shade will decrease leaves will fall off and yield will be low, but on the farm since we build fire belts they don't affect the fruit production of the farm.

- Yes, when he doesn't get enough fertilizer for his farm the fruit will cause low fruit production

- Some year they do not produce enough fruits. If you have less fruits every year it cannot bear fruits

- There is a change in fruit production on the fields where fert was applied small difference -- If rain doesn't come early in the year the fruit production will be low -

\section{8.) How does bush burning affect your shea trees? Do you do anything to protect them?}

\section{8-30}

- They don't get good fruit, he normally weeds around the trees

- Yes, but he prevents the fire from entering 
- Doesn't affect them they help yield more fruits in terms of burning the grass

- As they are growing, we keep fire belts around them so the fire can't come and burn them

- When the fire attacks the shea trees the flowers will not be many. So, if the flowers are not there will not be any fruits, fire belt

- The bush trees are burning more than in the farm. No, doesn't do anything to protect the trees you can't tell where the burning will come from

- Fire belt, fire causes less fruit production

- Yes, reduces the flowers and sometimes burning the fruits. Clean the farm to be nice

- He gets low fruit, but he doesn't let fire come on his field

- Doesn't affect them they help yield more fruits in terms of burning the grass

40-50

- If they set fire it causes the trees to have wounds how to withstand that condition until rainfall it is difficult. When they collect millet of sorghum they collect the stalks and pack them to survive.

- Bush burning causes the flowers to fall down from the trees.

- Yes, try to educate people not to burn them, build fire belts - belts around the farm.

- You will get low yield. He tries to make fire belt to prevent fire from entering

- Yes, when they are fruiting or flowering and they burn it too late (2nd burn) the fire heat will destroy everything. No protection only to stop burning.

- If fire burns the trees some of them won't produce again, they end up dying. Some trees don't produce well for a small time but they will continue to grow again. They protect them by burning the grass "small" before production to protect the fruit.

- When fire attacks his shea trees he does get low fruit. He never creates a fire belt.

- Yes, though fire it gives low fruit yield, he makes fire belt to prevent fire

- Yes, because at certain points this year there are a lot of grasses. If the burning delays the fire will disturb the leaves and flowers. It will reduce the fruit. yes, clears around the trees

\section{0-60}

- Yes, if it is flowering and the flames are high it will burn the flowers

- Since they are farming on the field the fire can't enter, but if they leave the farm, then the fire can burn the trees 
- Yes, it will affect the trees unless you build a fire belt. It will cause low fruit production.

- If they start the bush burning early the trees will be of, but when they start the bush burning late it will disturb the flowers. Uses fire belts to prevent on the farm

- weed around the crops - burning trees stops the shea from growing- Fire can cause the fruits to not come - it can take up to 5 years of farming the land again for the fruit to come in large quantities - if you leave the field fire comes

- Weed under the tree - difference between bush trees and farm trees - weeding makes a difference. Prevents bush burning, his father taught him about weeding to prevent bush fires. In charge of shea on farm

- Bush burning effects fields and trees. Will take years for the trees to bear fruit again. Also effects the fertility of the land.

\section{9.) Have you ever transplanted or planted shea?}

18-30

- No, he has never seen it.

- No

- No

- No

- No

- No

- No, have never seen it

- No

- No

- No

40-50

- The topography of the land makes survival difficult so he always tries to protect the trees but to plant them, it would be difficult for them to survive.

- No, but planted mango and achiapple

- No, they germinate on their own

- No

- No, when he is weeding he can see that certain trees will do fine, so he won't cut it but other than that nobody plants here.

- Don't plant, it is natural

- No

- He planted one to see. It has grown but it hasn't had fruit for him to see

- No

$50-60$

- No 
- No, he never planted

- Yes, he planted as an experiment. It worked very well. He hasn't done it again, but he would

- Rear, but don't plant. So if it germinates they will take care of it.

- Has planted shea. The fruit from one tree was good, so he wanted to grow that trees progeny

- He has the mindset to have a plantation of shea, but funding is a problem

\section{0.) Are there differences in the way men and women manage their farming practices? What are some of the differences?}

\section{8-30}

- Men goes to farm more frequently than women

- Yes, the men have time to attend to the farms more than them women. They also know how to farm better than the women. Men are always at the farm, but after harvesting women will never go there.

\section{0-40}

- Women need more labor, but the men can do some of the work by themselves

- Men, during the morning the women will be preparing the children to go to school but the men will go to the field

- Yes, men have more strength than the women

- Yes, assuming you want to clear your land, and trees are there, it is difficult for the women to remove them, but applying fertilizer and thing like that women can do

- Men always have the strength and courage of working more than the women on the farm.

- Yes, because women farms are usually bushy unless they hire people to weed it and that will cost them, but since men are physically strong they are always in the field to clean it.

- Yes, men can weed by themselves but the women cannot

\section{0-50}

- Yes, men specialize in one crop of the other, women like to intercrop because they can get the $\$$ to have an acre of just one crop such as maize, so they grow a bunch of things.

- Yes, men go early and cook food in the farm. Women hire labor, but men can do some of the labor themselves, women often can't. Men have women harvesters, women harvest their farms themselves

- Yes, men can maintain the farm more than them women, the men are strong more than the women. They are not strong. Even if you train her, she cannot do it.

- Yes, the germination of seeds is not even the same. If he wants, he will go to the farm to prevent the birds from eating the seeds, but women can't do it b/c they have to care for the children. Weeding, women have to hire their farms are always bushy. 
- Yes, men can make yam mounds, but women don't farm yams. Men help women to sow and the women also help the men to sow. the men weed the farm but the women don't weed. Women have to hire.

- There is a difference, he is used to farming women are not used to it. Some farming practices are difficult for women such as weeding

- If women have bushy fields and they don't have laborers early, the farm will spoil but men do not have to get labor early, he will go do it himself

- A woman, if she doesn't have income then she can't farm. A man can use his physical strength

- Men, because the women are always after people for help, but men always be in their farm to clear their land. Sometimes people help them and it makes their work faster

\section{0-60}

- Women have more time to pull out unwanted weed on their farm, since they farm smaller areas - especially during cotton farming

- Mostly the men do most of the farming practices, but there will be a time when they will be farming 50/50

- Women do the planting and harvest. The men's duty to plow the place. Manual plowing women can't do it.

- Women do not do yams, but other than that women can do any other food crop. Women are not permitted into yam faming as tradition, but the women can come and help. Women don't have the strength for hard labor

\begin{tabular}{|c|c|c|c|c|c|c|c|}
\hline age & Acres & Crops & Farms & Fallow & $\begin{array}{l}\text { Fallow } \\
\text { changed? }\end{array}$ & Rotates & extra \\
\hline 22 & 5 & maize, yam & 1 & 1 & no & & $\begin{array}{l}\text { He wants he land } \\
\text { to regain its } \\
\text { fertility }\end{array}$ \\
\hline 25 & 7 & $\begin{array}{l}\text { Maize } 1, \\
\text { soy } 1 \text {, rice } \\
1, \text { millet } 2 \text {, } \\
\text { yams } 2\end{array}$ & 1 & 5 & no & & $\begin{array}{l}\text { When you farm } \\
\text { on that place } \\
\text { there is no yield } \\
\text { so you have to } \\
\text { leave it for some } \\
\text { time }\end{array}$ \\
\hline 40 & 1 & Maize 1 & 1 & no & & yes & \\
\hline 32 & 7 & $\begin{array}{l}\text { Maize/ } \\
\text { guinea corn } \\
\text { cassava/ } \\
\text { yam } \\
\text { intercrop }\end{array}$ & 2 & 3 & no & yes & $\begin{array}{l}\text { There is land so } \\
\text { you can go to } \\
\text { your further place }\end{array}$ \\
\hline 33 & $51 / 2$ & $\begin{array}{l}\text { Yam } 1 / 2, \mathrm{gc} \\
1, \text { millet } 2 \text {, } \\
\text { maize } 2\end{array}$ & 1 & 3 & no & & $\begin{array}{l}\text { 18.) When it } \\
\text { loses its fertility }\end{array}$ \\
\hline
\end{tabular}




\begin{tabular}{|c|c|c|c|c|c|c|c|}
\hline 35 & $\sim 7$ & $\begin{array}{l}\text { Maize 6, } \\
\text { yam 1, } \\
\text { cassava }\end{array}$ & 1 & & & & $\begin{array}{l}\text { Yes, men he sees } \\
\text { that the farm he } \\
\text { is on is not fertile } \\
\text { anymore he will } \\
\text { go back to a } \\
\text { different farm }\end{array}$ \\
\hline 36 & 11 & $\begin{array}{l}\text { Rice } 5 \\
\text { maize } 5 \\
\text { okra } 1\end{array}$ & 2 & no & & $\begin{array}{l}2 \text { years } \\
\text { maize, } \\
1 \text { year } \\
\text { beans }\end{array}$ & \\
\hline 37 & 5 & $\begin{array}{l}\text { Maize, soy, } \\
\text { yam, millet }\end{array}$ & 3 & \multicolumn{2}{|c|}{$\begin{array}{l}2-3 \text { or } 4 \text { years due to } \\
\text { the nature of that } \\
\text { area }\end{array}$} & & $\begin{array}{l}\text { 18.) For it to } \\
\text { regain its fertility }\end{array}$ \\
\hline 38 & 7 & $\begin{array}{l}\text { yam, maize, } \\
\text { millet, } \\
\text { beans, } \\
\text { Bambara } \\
\text { beans }\end{array}$ & 2 & no & & & \\
\hline 40 & 1 & maize & 1 & no & & yes & \\
\hline 40 & 6 & $\begin{array}{l}\text { Maize 2, } \\
\text { millet 2, } \\
\text { cassava } 1, \\
\text { yam } 1\end{array}$ & 2 & 4 & 4 & & $\begin{array}{l}\text { The land loses } \\
\text { fertility if they } \\
\text { don't fallow. } \\
\text { Also since } \\
\text { fertilizer is hard } \\
\text { to come by he } \\
\text { has to fallow it }\end{array}$ \\
\hline 40 & 8 & $\begin{array}{l}\text { Yam1 } \\
\text { millet3 } \\
\text { maize2 gn2 }\end{array}$ & 1 & $2-3$ & $2-3$ & & $\begin{array}{l}\text { A certain type of } \\
\text { weed starts to } \\
\text { grow on the field } \\
\text { that makes } \\
\text { fertility low so he } \\
\text { has to leave }\end{array}$ \\
\hline 43 & & $\begin{array}{l}\text { Soy maize } \\
\text { rice } \\
\text { sorghum } \\
\text { cassava } \\
\text { yams }\end{array}$ & & 2 & 2 & & $\begin{array}{l}\text { Helps bring } \\
\text { nutrients to the } \\
\text { farm }\end{array}$ \\
\hline 45 & 6 & $\begin{array}{l}\text { yam, okra, } \\
\text { millet, soy }\end{array}$ & 2 & 3 & $\begin{array}{l}\text { Not every } 3 \\
\text { sometimes } 1 \\
\text { rotates crop }\end{array}$ & $\begin{array}{l}\text { jears, } \\
\text { just }\end{array}$ & $\begin{array}{l}\text { The land loses its } \\
\text { fertility and if } \\
\text { you plant there } \\
\text { you won't get } \\
\text { better yield }\end{array}$ \\
\hline 45 & 7 & $\begin{array}{l}\text { Gn2 gc1 } \\
\text { yam1 }\end{array}$ & 1 & 5 & $\begin{array}{l}\text { Sometimes } \\
\text { 3yrs, }\end{array}$ & & $\begin{array}{l}\text { If you don't } \\
\text { fallow you won't } \\
\text { get a good land if }\end{array}$ \\
\hline
\end{tabular}




\begin{tabular}{|c|c|c|c|c|c|c|c|}
\hline & & $\begin{array}{l}\text { maize } 2 \\
\text { beans } 1\end{array}$ & & & $\begin{array}{l}\text { sometimes } \\
2\end{array}$ & & $\begin{array}{l}\text { you fallow you } \\
\text { will get a good } \\
\text { yield }\end{array}$ \\
\hline 45 & 12 & $\begin{array}{l}\text { 9corn, } \\
\text { 1millet, } \\
2 \text { yam }\end{array}$ & 1 & no & & yes & \\
\hline 46 & $\sim 7$ & $\begin{array}{l}\text { 1/2 tomato, } \\
\text { yam, } 3 \\
\text { millet, } 2 \\
\text { maize, } 2 \\
\text { soy }\end{array}$ & 1 & $\begin{array}{l}\text { yes, 2- } \\
3 \\
\text { years }\end{array}$ & $\begin{array}{l}\text { yes, one } \\
\text { year } \\
\text { fallows }\end{array}$ & & $\begin{array}{l}\text { To leave it for } \\
\text { fertility - to let it } \\
\text { regain it fertility }\end{array}$ \\
\hline 46 & 25 & $\begin{array}{l}\text { Maize, soy, } \\
\text { yam, rice } \\
\text { sorghum, } \\
\text { watermelon, } \\
\text { okra }\end{array}$ & 1 & $\begin{array}{l}\text { Yes, } \\
\text { three } \\
\text { years }\end{array}$ & $\begin{array}{l}\text { Not every } \\
\text { year }\end{array}$ & & $\begin{array}{l}\text { When the land } \\
\text { loses it fertility, } \\
\text { he has to leave it }\end{array}$ \\
\hline 48 & 7 & $\begin{array}{l}\text { Yam, } \\
\text { millet, soy, } \\
\text { gc, maize }\end{array}$ & 2 & $\begin{array}{l}\text { Yes, } \\
3-4 \\
\text { years }\end{array}$ & no & & $\begin{array}{l}\text { Yes, because if } \\
\text { you are farming } \\
\text { on a particular } \\
\text { place the land } \\
\text { fertility changes. } \\
\text { His land is not all } \\
\text { that fertile, so he } \\
\text { has to change }\end{array}$ \\
\hline 50 & 6 & $\begin{array}{l}2 \text { maize, gc } \\
3, \text { yam } 1, \\
(2 \mathrm{gc})\end{array}$ & 3 & 3 & no & & $\begin{array}{l}\text { Too much rain } \\
\text { too much } \\
\text { sunlight - can } \\
\text { cause losses in } \\
\text { yields. Was } \\
\text { going to plant } \\
\text { maize, high fert } \\
\text { cost caused him } \\
\text { to switch }\end{array}$ \\
\hline 52 & 5 & $\begin{array}{l}\text { maize, } \\
\text { beans, rice, } \\
\text { soy, cowpea }\end{array}$ & & & & & \\
\hline 60 & 6 & $\begin{array}{l}\text { Yam 1, } \\
\text { sorghum 2, } \\
\text { maize 1, } \\
\text { beans } 1\end{array}$ & 2 & $\begin{array}{l}\text { Yes, } \\
4-5 \\
\text { years }\end{array}$ & $\begin{array}{l}\text { He has } \\
\text { gained } \\
\text { land, so he } \\
\text { has gained } \\
\text { years }\end{array}$ & & $\begin{array}{l}\text { If he doesn't he } \\
\text { cant control the } \\
\text { weeds }\end{array}$ \\
\hline 60 & 5 & $\begin{array}{l}\text { Maize, rice, } \\
\text { beans, gc, } \\
\text { yams }\end{array}$ & 2 & no & & $\begin{array}{l}\text { he } \\
\text { rotates } \\
\text { with } \\
\text { beans }\end{array}$ & \\
\hline
\end{tabular}




\begin{tabular}{|c|c|c|c|c|c|c|c|}
\hline 60 & 3 & $\begin{array}{l}\text { Yam } 1, \\
\text { maize } 1\end{array}$ & 2 & 2 & 2 & & $\begin{array}{l}\text { The rotation gets } \\
\text { more yield }\end{array}$ \\
\hline 61 & 100 & $\begin{array}{l}\text { Millet, } \\
\text { yams 2, } \\
\text { maize 3, } \\
\text { soy 1, } \\
\text { cassava } 1\end{array}$ & 2 & 5 & $\begin{array}{l}\text { Depends } \\
\text { on the } \\
\text { capital to } \\
\text { go into } \\
\text { farming. It } \\
\text { changes } \\
\text { the years }\end{array}$ & & $\begin{array}{l}\text { When the fertility } \\
\text { of the land is low } \\
\text { you leave the old } \\
\text { to go into the a } \\
\text { new }\end{array}$ \\
\hline 80 & 10 & $\begin{array}{l}\text { maize yam } \\
\text { beans } \\
\text { millet }\end{array}$ & 2 & $\begin{array}{l}7 \text { year } \\
\text { fallow }\end{array}$ & $\begin{array}{l}\text { sometimes } \\
\text { they will } \\
\text { go back } \\
\text { early to } \\
\text { prevent } \\
\text { bush } \\
\text { burning } \\
\text { from } \\
\text { destroying } \\
\text { their } \\
\text { mango and } \\
\text { cashew }\end{array}$ & no & $\begin{array}{l}\text { Doesn't have } \\
\text { enough to cover } \\
\text { all farm with } \\
\text { fertilizer. But he } \\
\text { will apply as } \\
\text { much as he can } \\
\text { hoping that he } \\
\text { will get } \$ \text { for the } \\
\text { best of his farm - } \\
\text { They can usually } \\
\text { get } \$ \text { for plowing } \\
\text { but fertilizer is } \\
\text { always a problem }\end{array}$ \\
\hline
\end{tabular}




\section{APPENDIX D}

Figures: $3,6,10$

Received via email on 25 March 2015

Fahimeh,

Following up on your email, you have my (Kenneth Kettler) permission to use any of my photos. If you need additional information please let me know.

Kenneth James Kettler

Figures: 2, 8

Adapted from d-maps.com please see following website for permission use:

http://d-maps.com/conditions.php?lang=en

Figure:

This figures was used from the Food and Agriculture Organization of the United Nations. Please see following website for permission use

http://www.fao.org/contact-us/terms/en/ 